\title{
3. LA PRIMACÍA DEL DERECHO COMUNITARIO SOBRE EL ORDENAMIENTO JURÍDICO ESTATAL: ASPECTOS CONSTITUCIONALES
}

\author{
MIGUEL-ÁNGEL ALEGRE MARTÍNEZ \\ Doctor en Derecho \\ Profesor Titular de Escuela Universitaria \\ Area de Derecho Constitucional \\ Universidad de León
}




\section{SUMARIO}

1. Introducción: Entidad del Derecho comunitario como sistema autónoMo.-2. Transferencia de competencias de los Estados a las Comunidades EuropeAS.-3. EL PRINCIPIO DE COMPETENCIA.-4. LA POSICIÓN DEL DERECHO INTERNACIONAL RESpecto del Derecho interno.-5. La primacia del Derecho comunitario sobre los ordenamientos jurídicos de los Estados miembros.-6. Problemática en el Derecho COMPARADO.-a) Derecho comunitario y ley nacional posterior. b) Los derechos fundamentales.-7. ANÁLISIS DE LA PRIMACIA EN RELACIÓN CON EL ORDENAMIENTO CONSTITUCIONAL ESPAÑOL.- -a) Derecho comunitario y sistema de fuentes. b) La ley nacional posterior y la constitucionalidad del Derecho comunitario. c) Derecho comunitario y derechos fundamentales. d) Derecho comunitario $y$ Comunidades autónomas.-8. ReCAPITULACIÓn.-ANEXo: LA DECLARACIÓN DE 1 DE JULIO DE 1992 Y EL CONTROL PREVIO DE CONSTITUCIONALIDAD DE LOS TRATADOS INTERNACIONALES. 
Revista de Derecho Político, núm. 38, 1994, pp. 93-173

\title{
3. LA PRIMACÍA DEL DERECHO COMUNITARIO SOBRE EL ORDENAMIENTO JURÍDICO ESTATAL: ASPECTOS CONSTITUCIONALES $(*)$
}

\author{
POR \\ MIGUEL-ÁNGEL ALEGRE MARTÍNEZ \\ Doctor en Derecho. Profesor Titular de Escuela Universitaria \\ Area de Derecho Constitucional \\ Universidad de León \\ 1. INTRODUCCIÓN: \\ ENTIDAD DEL DERECHO COMUNITARIO COMO SISTEMA \\ AUTÓNOMO
}

Las Comunidades Europeas llevan ya recorrido un camino de casi cuatro décadas, y han llegado a adquirir una importancia capital como fe'-

(*) Este trabajo tiene su origen en el realizado dentro de un curso de doctorado impartido en 1990 en la Facultad de Derecho de León por el prof. Dr. D. José Antonio Corriente Córdoba, actualmente catedrático de Derecho Comunitario en la Universidad Pública de Navarra. El autor quiere expresar su agradecimiento, por su valiosa colaboración, al profesor Corriente Córdoba, así como a los profesores de Derecho Internacional Público de la Facultad de Derecho de la Universidad de León, Dr. D. Romualdo Bermejo García y D. Carlos Valdés Diaz. Igualmente, a los profesores del Area de Derecho constitucional de la Universidad de León, y al catedrático y vicepresidente del Tribunal Constitucional, Dr. D. Luis López Guerra.

El trabajo fue concluido y enviado en mayo de 1992, por lo que, salvo en el anexo, son escasas las referencias al Tratado de la Unión Europea, vigente desde el 1 de noviembre de 1993. Se ha preferido, sin embargo, mantener el texto original, el cual recoge una problemática que sigue gozando de vigencia y actualidad.

Sobre la incidencia constitucional de este Tratado, puede verse, además de la bibliografía citada en el anexo, F. RUBıo LLORENTE, "La Constitución Española y el Tratado de Maastricht", Revista Española de Derecho Constitucional, n. 36, 1992, págs. 253265. También de obligada referencia es la obra de P. Pérez Tremps, Constitución Española y Comunidad Europea, Madrid, Civitas - Fundación Universidad-Empresa, 1993. 
nómeno económico, social, cultural y jurídico. La creación de las Comunidades, la consolidación de la realidad institucional que representan, y el camino que recorren hacia un Derecho común europeo son hitos fundamentales en la construcción de una Europa cada vez más unida.

Desde el 1 de enero de 1986, España forma parte de las Comunidades Europeas. Desde ese momento, nuestro horizonte jurídico se ha visto enriquecido, al pasar el Derecho comunitario a formar parte del Derecho aplicable en nuestro país ${ }^{1}$.

Dada la incidencia del Derecho comunitario en las diversas ramas del ordenamiento, su estudio ofrece un interés innegable para todo jurista. En particular, podemos afirmar que las peculiares características del sistema jurídico comunitario presentan especial interés para el estudioso del Derecho constitucional².

En efecto, el Derecho comunitario se presenta, en primer lugar, como un sistema jurídico autónomo respecto de los ordenamientos de los

1 C. F. Molina del Pozo, Manual de Derecho de la Comunidad Europea, Madrid, Trivium, 1987, pág. 321, ha definido el Derecho comunitario como un «conjunto organizado $y$ estructurado de normas y principios que determinan la organización, funcionamiento y competencias de las Comunidades Europeas". La adhesión de España a las Comunidades Europeas se produjo mediante el Tratado de 12 de junio de 1985. Al proceso español de integración en las Comunidades hay que añadir la firma del Acta Única en 1986, el ingreso en el Sistema Monetario Europeo en 1989, y su participación en el Tratado de Maastricht.

A lo largo de este trabajo se emplea a menudo la expresión «Comunidad Europea". En realidad, son tres las Comunidades, y no una sola. La expresión "Comunidad European tiene su fundamento en una Resolución del Parlamento Europeo, de 16 de febrero de 1968, que estimó que dicho término es apropiado para designar al conjunto de las instituciones creadas conforme a los tratados que establecen las tres Comunidades, es decir: la Comunidad Europea del Carbón y del Acero (CECA), constituida por el Tratado de París de 18 de abril de 1951; la Comunidad Económica Europea (CEE), también conocida como "Mercado Común", y constituida por el Tratado de Roma de 25 de marzo de 1957, y la Comunidad Europea de la Energía Atómica (CEEA o EURATOM), constituida por el Tratado de Roma de 25 de marzo de 1957. La CEE es la de mayor importancia por el ámbito de sus competencias conforme a su Tratado constitutivo, y a ella nos referiremos fundamentalmente. El Tratado de Maastricht recoge la denominación "Unión Europea».

2 Este interés reside, además de en los caracteres que veremos a continuación, en que supone la existencia de un Derecho constitucional europeo, basado en la Constitución -en el sentido formal del término-contenida en los tratados comunitarios, que funcionaría como "fuente de fuentes" del Derecho comunitario y como "Ley fundamental" de la Comunidad. Además, junto con los tratados comunitarios y sus sucesivas modificaciones ("Derecho originario"), que contienen la mayor parte del "Derecho constitucional de la Comunidad", nos encontramos con el "Derecho derivado", emanado unilateralmente por las instituciones comunitarias, el cual ha pasado también a formar parte de la realidad jurídica de los Estados miembros. Derecho originario y Derecho derivado son instrumentos al servicio del logro de los objetivos comunitarios. 
Estados miembros. Pero, al mismo tiempo, se halla integrado en el orden interno de los Estados, es inmediatamente aplicable y, como tal, puede ser invocado por los particulares ante los órganos jurisdiccionales estatales y debe ser aplicado por éstos. En este sentido se habla, en tercer lugar, de la eficacia directa del Derecho comunitario, en el sentido de que sus normas generan derechos y obligaciones para todos aquellos a quienes afectan, sean Estados miembros o particulares ${ }^{3}$.

Estos caracteres, relacionados entre sí, nos ofrecen la imagen de un sistema jurídico introducido en los ordenamientos de los Estados miembros para ser uniformemente aplicado en ellos conservando, al mismo tiempo, su carácter de sistema autónomo.

Todo ello denota una notable originalidad del Derecho comunita:rio y supone la aparición de problemas desde la óptica de la tradicional concepción de la soberanía estatal y de los principios constitucionales propios de cada Estado miembro.

En efecto, la coexistencia - y vigencia simultánea- en cada Estado miembro de su propio ordenamiento y del Derecho comunitario eu-

${ }_{3}$ Vemos reflejados estos caracteres, por ejemplo, en el artículo 189 del Tra tado constitutivo de la Comunidad Económica Europea (Roma, 25 de marzo de 1977; en adelante, TCEE), donde se establece el alcance de cada una de las manifestaciones normativas comunitarias, y queda reflejado el papel del Derecho comunitario como instrumento para el logro de los objetivos comunitarios. Así, del $\mathrm{Re}_{\overline{-}}$ glamento se dice que utendrá un alcance general. Será obligatorio en todos sus elementos y directamente aplicable en cada Estado miembro". El artículo 164 del mismo Tratado establece que «El Tribunal de Justicia garantizará el respeto del Derecho en la interpretación y aplicación del presente Tratadon. Precepto éste que de be ser puesto en relación con la figura del recurso prejudicial, regulado en el ar: tículo 177 del TCEE. Este Tratado recoge en su artículo 2 los fines de la Comunidad; y el artículo 5 es elocuente respecto de la actitud que deben mantener los paises integrantes respecto de los mismos: "Los Estados miembros adoptarán todas las medidas generales o particulares apropiadas para asegurar el cumplimiento de las obligaciones derivadas del presente Tratado o resultantes de los actos de las instituciones de la Comunidad. Facilitarán a ésta última el cumplimiento de su misión". $Y$ en el párrafo segundo: "Los Estados miembros se abstendrán de todas aquellas medidas que puedan poner en peligro la realización de los fines del presente Tratado". El artículo 4 TCEE encomienda a las instituciones comunitarias -Parlamento Europeo, Consejo, Comisión y Tribunal de Justicia- «la realización de las funciones asignadas a la Comunidad". Respecto de los caracteres del Derecho comunitario puede verse, por ejemplo, con carácter general, G. ISAAC, Manual de Derecho comunitario general, Barcelona, Ariel, 12." edición, 1985. Respecto de estos caracteres, y en particular del efecto directo, es obligado citar la Sentencia del Tribunal de Justicia de 5 de febrero de 1963, asunto 26/62, Onderneming van Gend and Loos. 
ropeo -como sistema autónomo pero intercalado en el interno-plantea, entre otros problemas, la posibilidad de conflicto entre la norma interna y la comunitaria y, por tanto, el interrogante sobre cuál de las dos debe considerarse prevalente.

La jurisprudencia del Tribunal de Justicia de las Comunidades Europeas ha proporcionado, como solución a este problema, el principio de primacía del Derecho comunitario respecto del Derecho interno de los Estados miembros.

La primacía aparece, así, como una característica del Derecho comunitario, con vistas a su aplicación uniforme, en la que vendrian a confluir los otros caracteres enumerados. De ella vamos a ocuparnos en las páginas siguientes.

En primer lugar, veremos cómo la integración de los Estados miembros en la Comunidad supone una transferencia de competencias a la misma y la posibilidad de eventuales conflictos que dicha transferencia genera. Se hablará a continuación de la posición que ocupa el Derecho internacional respecto del Derecho interno, como punto de partida para llegar al estudio de la primacía del Derecho comunitario. Nos referiremos después a la problemática suscitada en otros Estados miembros, los cuales, en determinados momentos, se han mostrado remisos a aceptar la primacía del Derecho comunitario, sobre todo en el supuesto de que éste vulnerara derechos fundamentales reconocidos en sus textos constitucionales. Por último, nos referiremos a la primacía en relación con nuestro propio ordenamiento.

\section{TRANSFERENCIA DE COMPETENCIAS DE LOS ESTADOS A LAS COMUNIDADES EUROPEAS}

La integración de los Estados miembros en las Comunidades Europeas se materializa en una transferencia de competencias. Existe, en efecto, una atribución competencial por parte de los Estados en favor de las instituciones comunitarias, con la limitación de la soberanía estatal que ello conlleva. En cualquier caso, cabe seguir hablando de una Comunidad, formada mediante la conclusión de acuerdos internacionales $y$ constituida por Estados independientes y soberanos ${ }^{4}$.

4 Entendemos aquí la soberanía estatal en su tradicional concepción, equivalente a supremacía. A este concepto se refiere A. TORRES DEL MORAL, Estado de De- 
Esa cesión de atribuciones se produce de modo voluntario, y en la mayoria de los Estados se ha articulado jurídicamente en los propios textos constitucionales de los Estados, mediante una previsión constitucional de atribución de competencias en favor de las Comunidades.

Así, según el artículo 24.1 de la Constitución alemana, "la Federạción podrá transferir derechos de soberanía, mediante ley, a instituciones internacionales". Ésta es también la técnica utilizada en otros países comunitarios, como Bélgica, Luxemburgo, Dinamarca, Holanda, Italia, Francia o España ${ }^{5}$.

recho y Democracia de Partidos, Madrid, Universidad Complutense, Servicio de Publicaciones de la Facultad de Derecho, 1991, pág. 36, como «el poder del Estado que se manifiesta como supremo en el orden interno y como independiente en el orden externo. Tanto en un orden como en otro se presenta como potestad de decisión última y efectiva". Sin embargo, esta concepción aparece hoy revisada por la propia realidad. Como señala este mismo autor al hablar del Estado "internacionalmente integrado" (ibidem, págs. 113 y ss.), muchos de los problemas actuales (políticos, militares, económicos, ecológicos o tecnológicos) no pueden ser abordados desde el aislamiento estatal, sino que requieren una solución supranacional. La integración en comunidades supranacionales, como lo es la Comunidad Europea, constituye un límite jurídico de la soberanía, buscado voluntariamente por los Estados para hacer frente a las necesidades planteadas. En cualquier caso, el hecho de que los Estados miembros hayan ingresado voluntariamente y conserven su independencia y el derecho de separarse de las Comunidades, da pie para poder seguir hablando de Estados soberanos, sin que por ello deba olvidarse que la cesión de competencias supone una revisión del concepto tradicional de soberanía. Ésta se ve sometida a una limitación consensual, jurídica y voluntaria.

5 Así, por ejemplo, la idea de cesión de soberanía está presente en el artículo 11 de la Constitución italiana, según el cual este país "...acepta, en condiciones de paridad con los demás Estados, las limitaciones de soberanía necesarias para crear un ordenamiento que asegure la paz y la justicia entre las naciones; promueve y favorece las organizaciones internacionales que tiendan a tal fin". Por su parte, el artículo 24.1 de la Constitución alemana establece que "La Federación podrá transferir derechos de soberanía, mediante ley, a instituciones internacionales». El artículo 53 de la Constitución francesa menciona los tratados «relativos a la organización internacional». El artículo 67 de la Constitución holandesa señala que "siempre que se observe, de ser necesario, lo dispuesto en el artículo 63, se podrán confiar por un Tratado o en virtud de éste competencias legislativas, administrati: vas y jurisdiccionales a organizaciones de Derecho internacional". En el mismo sentido, pueden verse los artículos: $\mathbf{4 9}$ bis de la Constitución luxemburguesa, 20 de la Constitución danesa, 10 de la Constitución sueca y 28 de la Constitución griega. El texto constitucional español, siguiendo esta técnica mayoritaria, establece en su artículo 93, inciso primero, que "mediante ley orgánica se podrá autorizar la celebración de tratados por los que se atribuya a una organización o institución internacional el ejercicio de competencias derivadas de la Constitución".

Otros paises han utilizado, para la recepción del Derecho comunitario, otra técnica: la aceptación explícita, sin previa cesión formal de soberanía, de la aplicación de las normas comunitarias, en las condiciones impuestas por los tratados y 
Aunque las Comunidades Europeas no gozan de competencias ilimitadas, los tratados constitutivos les confían amplias atribuciones para el logro de sus fines, y a ellos hay que acudir para definir cuál es el marco en que se mueven.

Sin embargo, los tratados no presentan una lista de materias atribuidas a la competencia de las Comunidades, como suele suceder en los Estados federales o autonómicos.

En efecto, si bien los tratados constitutivos describen los objetivos comunitarios (a este respecto hemos visto ya el art. 2 TCEE), lo que no contienen es la atribución automática a la Comunidad de todos los poderes necesarios para la realización de los mismos. $Y$ así, mientras el artículo 3 TCEE enumera las tareas que hay que realizar y los instrumentos que es necesario emplear para alcanzar los objetivos del Tratado, resulta que dichas tareas e instrumentos no son necesariamente confiados a la acción de la Comunidad, o al menos no lo son únicamente, ya que se prevé también la intervención de los Estados miembros, o de organismos que, en sentido estricto, no forman parte de la estructura institucional comunitaria?.

Al mismo tiempo, la jurisprudencia del Tribunal de Justicia de las Comunidades Europeas (en adelante, TJCE) subraya la cesión de soberanía de los Estados en favor de la Comunidad. Así, en la ya clásica sentencia Costa/ENEL, señala:

"A diferencia de los Tratados internacionales ordinarios, el Tratado CEE ha instituido un ordenamiento jurídico propio, que ha quedado integra-

con carácter prevalente respecto del Derecho interno, el cual no podrá contener disposiciones que impidan la aplicación del Derecho comunitario. Ésta es la solución adoptada por Irlanda (art. 29.4 de la Constitución), Reino Unido (European Communities Act de 1972) y Portugal (art. 8 de la Constitución). Respecto de esta segunda solución, A. Mangas Martin, "La reforma constitucional en España: los tratados internacionales (arts. 93 a 96 de la CE)", ponencia presentada al Congreso La reforma constitucional en España, Logroño, 27-30 abril 1992, publicada en Revista de Derecho Político, n. ${ }^{9} 36,1992$, señala que su calidad técnica es menor, si bien conduce al mismo resultado.

- Véase, a este respecto, A. TIZZANo, "Las competencias de la Comunidad", en VV.AA., Treinta años de Derecho Comunitario, Luxemburgo, Oficina de Publicaciones Oficiales de las Comunidades Europeas, 1984, págs. 45 y ss.

7 Con la finalidad de asistencia a las instituciones propiamente dichas, los párrafos 2 y 3 del artículo 4 TCEE se refieren al Comité Económico y Social y al Tribunal de Cuentas. La necesaria colaboración de los Estados se recoge en el artículo 5 TCEE, ya transcrito. Además, el artículo 6.1 del mismo Tratado, añade: "Los Estados miembros, en estrecha colaboración con las instituciones de la Comunidad, coordinarán sus respectivas políticas económicas en la medida necesaria para alcanzar los objetivos del presente Tratado. 
do en el sistema jurídico de los Estados miembros a partir de la entrada en vigor del Tratado, y que se impone a sus jurisdicciones; en efecto, al crearse una Comunidad de duración ilimitada, dotada de instituciones propias, de personalidad, de capacidad jurídica, con capacidad de representación internacional y, más concretamente, de poderes efectivos que emanan de una limitación de competencia o de una transferencia de atribuciones de los Estados a la Comunidad, éstos últimos han limitado, aunque en esferas delimitadas, sus derechos soberanos y creado, de esta forma, un derecho aplicable tanto a sus nacionales como a ellos mismos" ${ }^{8}$.

Así las cosas, se presenta una situación en la cual los Estados transfieren competencias a las Comunidades europeas, si bien, como ya hemos visto, los tratados comunitarios no ofrecen una precisa distribución de materias de competencia comunitaria. La realidad nos habla de un cada vez más amplio abanico competencial cedido en favor de la Comunidad.

Al mismo tiempo, como ya hemos anticipado, el Tribunal de Justicia comunitario ha sentado el principio de la prevalencia o primacía del Derecho comunitario.

Los principios de primacía y de competencia aparecen, por tanto, como complementarios en la configuración de las relaciones entre ambos sistemas jurídicos. En efecto, cada uno de estos principios vendría a matizar el alcance del otro, si bien la correcta aplicación del principio dé competencia no debe, en principio, permitir la existencia de demasiados supuestos de colisión entre las normas internas y las comunitarias.

Para aproximarnos a la comprensión de esas relaciones será necesario hacer referencia a ambos principios de articulación normativa.

\section{EL PRINCIPIO DE COMPETENCIA}

Como ya sabemos, los tratados comunitarios no contienen una lista de competencias y no las distribuyen con precisión entre la Comunidad y los Estados: las competencias son atribuidas a la Comunidad de forma específica y sectorial, con una intensidad que varía según los ca-

8 TJCE, Sentencia de 15 de julio de 1964, asunto 6/64, Costa/ ENEL, Recueil de la Jurisprudence de la Cour de Justice des Communautés Européennes, 1964, págs. 1159-1160. 
sos, y no siempre puede deducirse con claridad su alcance y extensión. Además, las obligaciones de los Estados miembros se precisan y consolidan en virtud de los caracteres del Derecho comunitario, que reconducen a la primacía de éste sobre el Derecho interno.

Nos encontramos, así, ante unas circunstancias que no facilitan la elaboración de criterios uniformes. Incluso la jurisprudencia del Tribunal de Justicia comunitario ha venido mostrando una gran dosis de pragmatismo, adaptando sus principios a las situaciones específicas que se han ido presentando.

En cualquier caso, parece necesaria en este punto una breve referencia a las clases o modalidades de competencias atribuidas por los tratados, para tratar de deducir algunas reglas de distribución competencial. Seguimos para ello a GUY ISAAC, el cual, al tratar el tema de las relaciones entre competencia nacional y comunitaria, distingue entre competencias reservadas a los Estados, competencias concurrentes y competencias exc/usivas ${ }^{9}$. págs. 48 y ss.

- G. IsAac, Manual de Derecho Comunitario General, op. cit., en nota 3,

Este autor, además, distingue aquí varias posibles clasificaciones de las competencias comunitarias. Así, en primer lugar, habla de competencias de control (que serían aquellas dirigidas a verificar el respeto de las obligaciones suscritas por los Estados) y competencias de acción (en virtud de las cuales las Comunidades están encargadas de actuar, de tomar las medidas necesarias para el cumplimiento de los fines y objetivos comunitarios. El primer tipo de competencias se encarga sobre todo a la Comisión (véanse los arts. 155 y 169 TCEE y 88 del Tratado constitutivo de la CECA - TCECA - $)$. De acuerdo con estos mecanismos, cada vez que los tratados establecen obligaciones para los Estados, acuerdan simultáneamente para las instituciones una competencia de control.

En segundo lugar, Guy Isaac habla de competencias de tipo internacionaly de tipo estatal, ya que, como sabemos, una de las peculiaridades de la construcción comunitaria consiste en que las Comunidades han sido habilitadas para ejecutar, además de competencias de tipo internacional, otras de tipo interno. Así, dentro de las primeras, pueden citarse el poder de información y consulta "para el cumplimiento de las tareas que le han sido confiadas", que obligando a los Estados miembros a informar o a consultar a las instituciones comunitarias antes de adoptar determinadas medidas (véanse, por ejemplo, los arts. 103 ó 213 TCEE). Igualmente, la coordinación de políticas y comportamientos de los Estados (a través, sobre todo, de recomendaciones y dictámenes - art. 155 TCEE - y también de directivas, sobre todo cuando se trata de la coordinación de las legislaciones nacionales -arts. 54, 57 y 100 TCEE-). Las competencias de tipo estatal serían aquellos poderes que las instituciones comunitarias pueden ejercer directamente sobre los ciudadanos de los Estados. Por ejemplo, poderes de tipo judicial, administrativo $y$, sobre todo, legislativo, que afectan directamente a los operadores económicos y, de manera general, a todos los ciudadanos (recuérdese, por ejemplo, lo dicho sobre la vinculatoriedad de los reglamentos. También el Tribunal de Justicia tiene contacto directo con 
En principio, hay que señalar que todas las competencias no atribuidas a la Comunidad siguen reservadas a los Estados ly no sólo las que les están expresamente reservadas según los artículos 36,223 , etc., TCEE).

En estos ámbitos, los Estados conservan la totalidad de sus poderes, pero no por ello quedan exentos de "las incursiones de la competencia comunitaria en las soberanías nacionales", cuando ello sea necesario para que los efectos del Tratado no se vean disminuidos y su finalidad comprometida en virtud de esos poderes retenidos por los Estados miembros ${ }^{10}$.

Ejemplos de materias que quedan reservadas a este tipo de competencias serían la política de enseñanza o las obligaciones activas y pasivas que se desprenden del udeber de colaboración de los Estados miembros" (arts. 86 TCECA, 5 TCEE y 192 TCEEA).

Por otra parte, y en general, las competencias atribuidas a la Comunidad son competencias concurrentes, en el sentido de que los Estados conservan su competencia de legislar o de adoptar compromisos con terceros países en la medida en que las autoridades comunitarias no hayan intervenido aún. Por ello, sucede que el ejercicio efectivo de las competencias comunitarias exc/uye progresivamente la competencia nacional. De esta manera, mientras la Comunidad no ejerza su competencia, los Estados están autorizados a mantener o a tomar en el marco nacional las medidas apropiadas, si bien vinculados por las estipulaciones generales del Derecho comunitario. Si la Comunidad ha empezado a ejercer su competencia sobre una materia pero no la ha agotado todavía, la intervención de los Estados es posible, pero debiendo respetar los tratados, principios generales, obligaciones de cooperación y, además, las medidas ya dictaminadas por las instancias comunitarias, no poniendo en peligro los objetivos y funcionamiento del régimen instaurado. Ejemplo típico sería el de la política agrícola común ".

Según ha establecido el Tribunal de Justicia, desde que la Comunidad ha ejercido íntegramente su competencia en cierto campo, las dis-

los particulares -arts. 172 y 173 TCEE--). Además, las Comunidades están habilitadas para establecer acuerdos internacionales con los que se creen directamente derechos $u$ obligaciones para los particulares, y con fuerza de derecho positivo en el territorio de los Estados miembros.

${ }_{10}$ TJCE, Sentencia de 23 de febrero de 1961, asunto 30/59, Gezamenlijke Steenkolenmijnen.

11 TJCE, Sentencia de 16 de marzo de 1977, asunto 68/1976, Comisión/Francia; igualmente, Sentencia de 8 de mayo de 1977, asunto 111/76, Van der Hazel. 
posiciones adoptadas por ella excluyen todas las disposiciones divergentes de los Estados miembros, con lo cual se observa ya la presencia del principio de primacía, complementario del de competencia a la hora de determinar la articulación normativa de ambos sistemas. Esta intervención comunitaria no sólo prohíbe a los Estados miembros legislar en la materia, sino también comprometerse convencionalmente con países terceros ${ }^{12}$.

Por último, existen algunos ámbitos, en los cuales el Tribunal de Justicia ha afirmado la existencia de competencias comunitarias exclusivas, cuando expire cierto plazo, independientemente del hecho de que la Comunidad no haya ejercido sus poderes. No obstante, para evitar vacíos jurídicos, los Estados han seguido habilitados, en los casos en que falta la regulación comunitaria, para regular la materia, aunque sometidos a autorización, control o incluso aprobación por parte de las instituciones comunitarias. Así se ha pronunciado el Tribunal, por ejemplo, respecto de los recursos biológicos del mar, la política comercial común, etc. ${ }^{13}$

Con ello, puede afirmarse que, si bien el no ejercicio por parte de la Comunidad de las competencias que se le atribuyen autoriza a los Estados para seguir legislando en la materia, de ninguna manera puede ello provocar la caducidad de la competencia ${ }^{14}$.

No hay que olvidar, además, que existe por parte de los Estados una transferencia de competencias en favor de la Comunidad. El conjunto de criterios que acabamos de ver, junto con la idea de transferencia, vendría a suponer para los Estados una ejecución y un ejercicio en común de la competencia en el marco de la estructura institucional comunitaria. Ello hace que en cualquier caso siga vigente el principio general de que, incluso en los casos en que los Estados miembros sigan conservando una esfera de competencia, esa regulación nacional sólo será admisible a condición de no causar perjuicio a la aplicación uniforme de las normas comunitarias ni a la plena efectividad de los actos adoptados en aplicación de estas normas ${ }^{15}$.

12 TJCE, Sentencia de 16 de febrero de 1978, asunto 61/77, Comisión/lrlanda; asimismo, véase Sentencia de 31 de marzo de 1971, asunto 22/70, Comisión/Consejo.

13 TJCE, Sentencias de 1 de julio de 1976, asuntos 3, 4 y 6/76, Kramer, y 15 de diciembre de 1976, asunto 41/76, Donckerwolcke.

14 TJCE, Sentencia de 14 de diciembre de 1971, asunto $7 / 71$. Comisión/Francia.

${ }_{15}$ TJCE, Sentencia de 13 de enero 1969, asunto 14/88, Wilhelm; en el mismo sentido, Sentencia de 10 de julio de 1980 , asuntos $253 / 78$ y 1 a $3 / 79$, Guerlain y otros. 
Es preciso señalar, además, que el artículo 235 TCEE permite una expansión de las competencias comunitarias. Según este precepto, "cuando una acción de la Comunidad resulte necesaria para lograr, en el funcionamiento del Mercado Común, uno de los objetivos de la Comunidad, sin que el presente Tratado haya previsto los poderes de acción necesarios al respecto, el Consejo, por unanimidad, a propuesta de la Comisión y previa consulta al Parlamento Europeo, adoptará las disposiciones pertinentes". Este precepto (junto con otros, tales como el art. 45.1 TCECA o el art. 203 TCEEA) viene a regular un sistema de ampliación de las competencias comunitarias para hacer frente de manera formal, pero mediante procedimientos más flexibles que los de revisión de los tratados (art. 96 TCECA, art. 236 TCEE y art. 204 TCEEA), a las necesarias adaptaciones sucesivas. Estamos en este caso (si hablamos de los tratados como "Constitución europea») ante un mecanismo que mitiga la "rigidez constitucional", sin que pueda encuadrarse propiamente en la figura de las modificaciones no formales de la Constitución, Verfassungswandlung, o mutaciones constitucionales.

Vemos que, al fin y al cabo, el principio de competencia ha de ser puesto en relación con los objetivos comunitarios. El Tratado no recoge exhaustivamente las competencias comunitarias, sino que deja abierta la posibilidad de su ampliación, siempre que dicha ampliación sea necesaria para el logro de los fines de la Comunidad.

El artículo 235 TCEE, y el hecho de que, como hemos visto, los tratados hayan atribuido competencias a la Comunidad de modo muy genérico, hacen que las regulaciones comunitarias incidan normalmente sobre materias antes "ocupadas" por normas estatales. Con ello se plantea el problema de ver si las competencias exclusivas comunitarias lo son hasta el punto de que su ejercicio no sólo desplace cualquier norma contraria, sino que impida también a los legisladores estatales regular tales materias, aunque sea a título complementario.

Al tratar este problema, S. MUÑOZ MACHADO recuerda una doctrina sobre la ocupación del espacio normativo desarrollada por el Tribunal Supremo norteamericano: la doctrina de la preemption. El Tribunal Supremo estadounidense no ha establecido reglas de valor general y absoluto sobre este problema. Su jurisprudencia es casuística: analiza cada caso y establece soluciones particulares, por lo difícil que es establecer criterios generales. El problema al que trata de dar solución la doctrina de la preemption es el de saber cuándo una competencia federal es exclusiva en sentido técnico estricto: cuándo la regulación de una materia queda monopolizada por un legislador con exclusión de cualquier otro. Se trata de ver, pues, si la ocupación del terreno normativo por la regulación federal es total y excluyente. 
Como hemos visto, similares problemas se plantean entre el Derecho comunitario y el Derecho interno, y parece que tampoco la jurisprudencia del Tribunal de Justicia ha llegado a conclusiones generales, demostrando aquí una tendencia al pragmatismo, valorando caso por caso cuándo los intereses comunitarios exigen que la competencia sea asumida de forma exclusiva y con carácter de monopolio. Asi, en materia de política comercial se ha defendido la idea de la competencia exclusiva y excluyente, si bien, haciendo uso del mencionado pragmatismo, admite que se puedan dictar por los Estados medidas de protección en colaboración con la Comisión, tras haberla consultado y aceptado sus objeciones, tal y como se refleja en la Sentencia de 5 de mayo de 1981 (Comisión/Reino Unido). También en política agraria se ha evolucionado desde planteamientos muy rígidos hasta soluciones más flexibles ${ }^{16}$.

Por otra parte, la jurisprudencia comunitaria se ha mostrado favorable a las habilitaciones o redelegaciones, es decir, a que, "ocupada" una materia por el legislador comunitario, pueda éste autorizar al legislador nacional a que colabore con él para completar esas regulaciones mediante normas que tendrán su apoyo en esa autorización, y no en competencias propias. De todas formas, el Tribunal ha actuado de forma bastante restrictiva a la hora de utilizar esas habilitaciones ${ }^{17}$.

Lo que parece claro es que el Tribunal no acepta que puedan producirse normas internas que contradigan a las comunitarias, pero en lo que concierne a establecer si las normas comunitarias deben necesariamente agotar la regulación de la materia o pueden dejar espacio para decisiones nacionales complementarias, el Tribunal se muestra más flexible.

De nuevo aparece aquí, entonces, el principio de primacía que vamos a estudiar a continuación, $y$ vemos el papel complementario que ambos principios juegan en la interrelación normativa entre Derecho comunitario y Derecho interno. En principio, las colisiones entre normas comunitarias y normas internas no tienen por qué producirse en virtud del principio de competencia. Pero si, por una insuficiente concreción del principio o bien por interpretaciones incorrectas del mismo o por extrali-

16 Véase, respecto de este tema, S. Muñoz Machado, El Estado, el Derecho interno y la Comunidad Europea, Madrid, Civitas, 1986, págs. 170 y ss., a quien seguimos fundamentalmente en esta parte de la exposición.

17 El Tribunal de Justicia se ha mostrado favorable a esas «redelegaciones", por ejemplo, en Sentencias de 17 de diciembre de 1970, asunto Scheer; de 30 de noviembre de 1978, asunto Susonne, y de 27 de septiembre de 1979, asunto Eridamia. El carácter restrictivo se aprecia, por ejemplo, en Sentencias de 12 de diciembre de 1972 (asunto Grisoli), 11 de febrero de 1971 (asunto Felischkontor), etc. 
mitaciones en el uso de la propia competencia, esa colisión llegara a producirse, en esos casos el Derecho de las Comunidades prevalece sobre el estatal. Por otra parte, a la vista de lo ya expuesto, es claro el carácter de primacía del Derecho comunitario sobre el ordenamiento interno en materias de competencia comunitaria. Cuáles sean estas materias será algo que venga determinado, en ocasiones, por los mismos Tratados, y en otras por los criterios elaborados por el Tribunal de Justicia. Sin olvidar que el ámbito competencial de las Comunidades aumenta progresivamente en virtud de la creciente cesión de competencias por parte de los Estados miembros.

Vamos, pues, a estudiar la primacía del Derecho comunitario, si bien antes la situaremos dentro del marco general de la posición del Derecho internacional respecto del Derecho interno.

\section{LA POSICIÓN DEL DERECHO INTERNACIONAL RESPECTO DEL DERECHO INTERNO}

El Derecho comunitario europeo es, ante todo, Derecho internacional, en cuanto que se basa, originariamente, en tratados internacionales. Por eso se hace necesaria una breve referencia a las relaciones del Derecho internacional con los ordenamientos internos como introducción al tema de la primacía del ordenamiento comunitario, sin que esto suponga olvidar las peculiaridades que éste presenta respecto del Derecho internacional general. Téngase presente, a este respecto, que, mientras los sujetos del Derecho internacional público son los Estados, en el Derecho comunitario los sujetos no sólo son los Estados miembros, sino también sus ciudadanos. Además, el Derecho comunitario no sólo lo componen los tratados constitutivos, sino que también existen normas comunitarias derivadas (reglamentos, directivas, etc.) que, con mayor o menor intensidad, pasan a formar parte del Derecho aplicable en los Estados miembros, en los términos del artículo 189 TCEE. Y es que, como ya sabemos, a diferencia de los tratados internacionales ordinarios, los tratados de las Comunidades Europeas han instituido un ordenamiento jurídico propio, integrado en el sistema jurídico de los Estados miembros, aplicable a dichos Estados $y$ a sus ciudadanos, y que se impone a las jurisdicciones estatales. Las normas comunitarias vienen, así, a ocupar un lugar en el orden jurídico interno, y los jueces nacionales tienen obligación de aplicarlas.

Hechas estas salvedades, hay que afirmar que la supremacía del Derecho internacional sobre los ordenamientos estatales no ha sido siempre aceptada. 
Aun a riesgo de una excesiva simplificación, podemos agrupar las posiciones doctrinales en dos corrientes: la monista y la pluralista, pudiendo considerar como intermedia una posición pseudomonista ${ }^{18}$.

Las doctrinas pluralistas arrancan de los planteamientos de TRIEPEL, acogidos por ANZILOTTI, en virtud de los cuales existe una separación radical entre el ordenamiemto jurídico internacional y los ordenamientos internos ${ }^{19}$.

La posición pseudomonista, a la cabeza de la cual encontramos a JELLINEK, y que fue seguida por los ZORN, WENZEL y VERDROSS, considera que el Derecho internacional se subordina al Derecho interno de cada país. El Derecho internacional es sólo un Derecho externo, común a varios Estados, y cada Estado determina los órganos competentes para concluir los tratados, que son la fuente del Derecho internacional. Se trata de una posición voluntarista, pues considera que el Derecho internacional no puede emanar de ninguna autoridad que no sea la propia voluntad de los Estados. Esta posición ha sido abandonada en la actualidad, y es la propia realidad la que ha venido a desecharla.

Para las doctrinas monistas, existe una unidad en el ordenamiento jurídico: Derecho internacional y Derecho estatal constituyen un solo sistema jurídico. La mayoría de las formulaciones monistas parten de la Escuela de Viena, encabezada por KELSEN, cuya concepción normativista encuentra el último fundamento de la validez del Derecho no en la voluntad, sino en la norma superior.

Como señala DÍEZ DE VELASCO, cualquiera que sea la posición teórica, lo cierto es que los legisladores estatales se preocupan del Derecho internacional, ya sea general o particular, con objeto de adoptarlo en los ordenamientos internos. Esa adopción se revela como necesaria para que los Tribunales y autoridades internas puedan aplicarlo. Los órganos estatales actúan de acuerdo con la normativa interna. Por eso, no podrían aplicar el Derecho internacional si el legislador interno no provee al respecto.

En cualquier caso, parece que, en caso de duda, la actuación de los órganos $y$ autoridades internos debe ser conforme a las prescripciones

18 Para mayor información sobre estas posiciones doctrinales, véase $M$. DiEz DE VELASCO, Instituciones de Derecho internacional público, Madrid, Tecnos, 8. edición, 1988, tomo I, págs. 164 y ss., a quien seguimos fundamentalmente en esta parte de la exposición.

19 M. Díez de VeLASCo, ibidem, cita a este respecto los trabajos de TrIEPEL, Völkerrecht und Landesrecht, obra publicada en 1899, y de ANziLotTI, II Diritto Internazionale nei giudizi interni, de 1905. 
del Derecho internacional que obliguen a su Estado. Pero, en caso de que una ley sea contraria a un tratado, y salvo prescripción interna en contrario, no podrían sino aplicar la norma interna, aunque tal actitud generaría responsabilidad internacional del Estado ${ }^{20}$.

Para evitar estos conflictos, lo normal es que el legislador interno adapte su ordenamiento a las exigencias del Derecho internacional, que formará parte del sistema de fuentes del Derecho de ese Estado. En este sentido es ilustrativo que, en determinados ordenamientos, la introducción en el ordenamiento de tratados que contengan disposiciones contrarias a la Constitución requiera la previa revisión constitucional. Ello viene, por una parte, a salvar el papel de norma estatal suprema de la Constitución, pues este mecanismo evita la coexistencia de la Constitución con una norma que le sea opuesta; pero, al mismo tiempo, nos habla de esta previsión de adaptación del Derecho constitucional interno al Derecho internacional ${ }^{21}$.

20 M. Dízz de Velasco, ibidem, págs. 169-170.

21 Así se establece en el artículo 54 de la Constitución francesa y también en el artículo 95 de la Constitución española. Estamos ante el supuesto de control previo de constitucionalidad de los tratados internacionales, sobre el que puede consultarse, por ejemplo, P. CRUZ VILLALÓN, "El control previo de constitucionalidad", Revista de Derecho Público, 2. época, n. 82, enero-marzo 1981, págs. 5-21. El carácter de la Constitución como norma suprema se salva también con la posibilidad de control de constitucionalidad a posteriori para los tratados internacionales (en nuestro ordenamiento, son susceptibles de recurso y de cuestión de inconstitucionalidad [arts. 161.1.a) y 163 de la Constitución y 27.2.c) y 35 de la Ley Orgánica del Tribunal Constitucional]. De todas formas, hay que señalar que la modalidad de control previo de los tratados encuentra su justificación, precisamente, en la posición que ocupa el Derecho internacional respecto del ordenamiento interno. Es lógico, en efecto, que se quiera asegurar la constitucionalidad de un compromiso que va a generar obligaciones internacionales de las que resulta difícil desligarse. La seriedad del compromiso internacional queda patente a la vista de la redacción de lós artículos 26 y 27 de la Convención de Viena, de 22 de mayo de 1969, sobre el Derecho de los Tratados. Según estos preceptos, «todo tratado en vigor obliga a las partes y debe ser cumplido por ellas de buena fe". "Una parte no podrá invocar las disposiciones de su Derecho interno como justificación del incumplimiento de un tratado". En los mismos términos, los artículos 26 y 27.1 de la Convención de Viena, de 21 de marzo de 1986, sobre el Derecho de los Tratados entre Estados y Organizaciones Internacionales, o entre Organizaciones Internacionales. La posición del tratado como fuente del Derecho interno y la dificultad para desentenderse de las obligaciones que contenga se reflejan en el artículo 96.1 de nuestro texto constitucional, en virtud del cual "los tratados internacionales válidamente celebrados, una vez publicados oficialmente en España, formarán parte del ordenamiento interno. Sus disposiciones sólo podrán ser derogadas, modificadas o suspendidas en la forma prevista en los propios tratados o de acuerdo con las normas generales del Derecho internacional". Sobre el control previo de tratados, me remito a mi trabajo El control previo de constitucionalidad: estudio comparativo, de próxima publicación, y la bibliografía que allí se cita. 
Lo que no ofrece dudas es que, si bien una concepción tradicional del Derecho internacional contemplaba a éste dentro del marco de una Comunidad internacional compuesta por Estados soberanos, y esta situación aún perdura en buena medida, hoy esa concepción ha de ser revisada a la luz del fenómeno de las Organizaciones internacionales.

Así, al lado de los tradicionales objetivos nacionales, los Estados integrados en estas organizaciones trabajan también por la consecución de objetivos supranacionales. Esta idea lleva a la afirmación de la necesaria primacia del Derecho internacional sobre el Derecho interno para que sea posible el logro de esos objetivos. En efecto, si los Estados necesitan integrarse en organizaciones supranacionales para alcanzar unos objetivos y cubrir unas necesidades a las que no pueden hacer frente de forma aislada, es lógico que, en aras del logro de esos objetivos, la integración se realice con todas las consecuencias, y entre ellas el reconocimiento de la prevalencia del ordenamiento supranacional.

Ejemplo típico de ello nos lo ofrece la Comunidad Europea, y desde esta perspectiva se puede comprender mejor el principio de primacía del Derecho comunitario sobre el Derecho interno.

\section{LA PRIMACIAA DEL DERECHO COMUNITARIO SOBRE LOS ORDENAMIENTOS JURIDICOS DE LOS ESTADOS MIEMBROS}

De entre las posiciones doctrinales que hemos contemplado en el apartado anterior para definir las relaciones entre el Derecho internacional y el Derecho interno, sin duda es la monista la que debe aplicarse respecto del Derecho comunitario.

Los propios tratados constitutivos nos revelan esa concepción monista de las relaciones con el Derecho interno. Así, por ejemplo, el artículo 189 TCEE, cuando señala que el Reglamento es "directamente aplicable en cada Estado miembro". Lo mismo puede afirmarse a la vista del artículo 177 TCEE, que regula el recurso prejudicial, el cual permite a las jurisdicciones nacionales remitir al Tribunal de Justicia las cuestiones sobre la interpretación o apreciación de la validez del Derecho comunitario. En definitiva, el Derecho comunitario, tanto el originario como el derivado, está orientado hacia el logro de los objetivos comunitarios, y para la 
consecución de éstos genera una serie de obligaciones. Entre ellas, la adaptación del Derecho interno a las nuevas exigencias ${ }^{22}$.

Sin embargo, los tratados constitutivos no contienen una mención expresa de la primacía. Ha sido la jurisprudencia comunitaria — con el fin de evitar el riesgo de que cada Estado atribuyera al Derecho comunitario un rango dentro de su ordenamiento- la que se ha ocupado de establecer esta característica esencial y de explicar el fundamento de la misma, labor esta última que también ha sido realizada por la doctrina.

A este respecto, R. KOVAR señala que la primacía es una consecuencia que se deriva necesariamente de la noción misma de Mercado Común, objetivo primero de la construcción comunitaria, lo cual se expresa en una ordenamiento jurídico propio, marcado por los imperativos de unidad, uniformidad y eficacia. Para el logro de estos fines se pretende una aplicación uniforme del Derecho comunitario, a través de sus caracteres, y especialmente de la primacia, que asegura la aplicabilidad y el efecto directo. De hecho, si bien los Tratados no enuncian directamente, como sabemos, este carácter, muchas de las disposiciones de los mismos no podrían concebirse sin él. Tal es el caso de los artículos 177, 169, 170 y 171 TCEE, que instituyen procedimientos judiciales que implican la superioridad del Derecho comunitario ${ }^{23}$.

En cualquier caso, parece que el fundamento ha de buscarse, sobre todo, en la misma naturaleza de las Comunidades, es decir, en su naturaleza específica y original, que se refleja en la misma noción de "Comunidad", con vocación de permanencia y unos objetivos concretos, que excluyen la unilateralidad estatal, y en la transferencia efectuada por los Estados en favor del Derecho comunitario, que conlleva una limitación objetiva de sus derechos soberanos.

22 No pretendemos en este trabajo detenernos a estudiar las competencias específicas de cada institución comunitaria ni las distintas fuentes del Derecho comunitario, su fuerza obligatoria, la necesidad o no de instrumento jurídico interno para su eficacia, etc. Véanse, a este respecto, los artículos 4 TCEE, así como la quinta parte del mismo (arts. 137 y ss.). Pueden verse, además, los trabajos de G. ISAAC, Manual de Derecho comunitario general, op. cit. en nota 3; VV.AA., Treinta años de Derecho comunitario, op. cit., en nota 6; S. MuÑOz MACHADO, El Estado, el Derecho interno y la Comunidad Europea, op. cit., en nota 16; R. Alonso García, Derecho comunitario, Derechos nacionales y Derecho común europeo, Madrid, Civitas y Servicio de Publicaciones de la Universidad Complutense, 1989; J. FERNÁndez Costales, «El Derecho civil español y el Derecho comunitario europeon (I y II), Actualidad Civil, n. ${ }^{\text {os }} 3$ y 4 , enero 1986 , etc.

${ }_{23}$ Véase, a este respecto, R. Kovar, "Relaciones entre el Derecho comunitario y los derechos nacionales", en VV.AA., Treinta años de Derecho comunitario, op. cit., en nota 6 , págs. 118 y ss. 
Esta idea de. la necesidad de la primacía como instrumento para el logro de los objetivos comunitarios se halla también presente en la jurisprudencia comunitaria, que afirma con claridad la prevalencia del Derecho comunitario sobre el interno.

A este respecto, es obligado referirse de nuevo a la ya citada Sentencia del TJCE de 15 de julio de 1964, Costa/ENEL, la cual subraya el carácter de primacía en los siguientes términos:

«...Surgido de una fuente autónoma, el Derecho nacido del Tratado no podría, pues, en razón de su naturaleza específica original, dejarse oponer judicialmente un texto interno de cualquier clase que sea, sin perder su carácter comunitario y sin cuestionarse la base jurídica misma de la Comunidad...

...La transferencia operada por los Estados, de su ordenamiento jurídico interno en beneficio del ordenamiento jurídico comunitario, de los derechos y obligaciones correspondientes a las disposiciones del Tratado, implica, pues, una limitación definitiva de sus derechos soberanos contra la cual no puede prevalecer un acto unilateral ulterior incompatible con la noción de Comunidad."

Esta misma sentencia, en el párrafo que reproducíamos en páginas anteriores, viene a recordar que la transferencia de competencias, y consiguiente limitación de los derechos soberanos, se ha realizado en esferas delimitadas. Queda claro entonces que la primacía afecta a las materias de competencia comunitaria, con lo cual puede apreciarse de nuevo la interrelación entre la primacía y la competencia en la articulación jurídica entre Derecho comunitario y Derecho interno.

A la vista de lo anterior, hay que afirmar que la naturaleza de la Comunidad, en la cual encuentra su fundamento la primacía, implica la primacía de todo el Derecho comunitario. Tanto el Derecho originario como el derivado prevalecerán sobre la norma interna incompatible, cualquiera que sea el rango de ésta ${ }^{24}$.

Otra importante sentencia del Tribunal de Justicia, la sentencia Simmenthal, ha venido a llamar la atención sobre el papel que el juez nacional -como aplicador del Derecho- ha de jugar a la hora de asegurar esa primacía:

${ }^{24}$ Véase J. V. LouIs, El ordenamiento juridico comunitario, Bruselas, 2. ${ }^{a}$ edición, 1986, pág. 127. Asimismo, M. R. Torres Hernández, "La primacía del Derecho comunitario", Tapia, n. 49, diciembre 1989, pág. 19. 
«...Todo juez nacional competente en una materia determinada tiene obligación de aplicar íntegramente el Derecho comunitario y proteger los derechos que éste confiere a los particulares, dejando sin aplicación toda disposición eventualmente contraria de la Ley nacional anterior o posterior a la norma comunitarian...

...El juez nacional encargado de aplicar, en el marco de su competenciạ, las disposiciones del Derecho comunitario, tiene obligación de asegurar el pleno efecto de estas normas, dejando inaplicada, si fuera necesario, en virtud de su propia autoridad, toda disposición contraria de la legislación nacional, incluso posterior, sin que para ello tenga que pedir o esperar su previa eliminación por via legislativa o por cualquier otro procedimiento constitucional. ${ }^{25}$

La primacía del Derecho comunitario ha de predicarse, incluso, respecto de los textos constitucionales de los Estados miembros.

Veremos en el próximo apartado la problemática que ello ha generado en materia de derechos fundamentales. Lo que sí podemos adelantar ahora, aunque volveremos sobre ello en relación con el caso español, es que, respecto del Derecho comunitario, no es posible la utilización de los mecanismos de control de constitucionalidad que se utilizan para las normas estatales ${ }^{26}$.

En efecto, las normas comunitarias derivadas no han de adecuarse a las Constituciones de los Estados miembros, sino al Derecho comunitario originario, el cual será el único "parámetro de constitucionalidad" del derecho derivado; y la aplicación del ordenamiento comunitario corresponde al Tribunal de Justicia de la Comunidad. Los Tribunales Constitucionales de los Estados miembros no son, por tanto, competentes para pronunciarse sobre la constitucionalidad del Derecho comunitario, ya que su cometido consiste en decidir sobre la adecuación o no a la Constitución de las normas internas.

Con ello, los jueces ordinarios nacionales no podrán pedir al respectivo Tribunal Constitucional la declaración de inconstitucionalidad de

${ }_{25}$ TJCE, Sentencia de 9 de marzo de 1978, asunto 106/77, Simmenthal, Rec. 1978 , págs. 620 y ss.

${ }_{26}$ Esta idea, que se encuentra presente en los párrafos de la sentencia Simmenthal que acabamos de transcribir, se halla también en el auto del TJCE de 22 de junio de 1965, donde se afirma que los Estados miembros se han adherido al Tratado sin otras reservas que las establecidas en los Protocolos, y por ello sería contraria al ordenamiento jurídico comunitario toda pretensión, por parte de un Tribunal de un Estado miembro, de poner dicha adhesión en tela de juicio, lo que conduciria a vaciar la Comunidad de toda sustancia. 
una norma comunitaria. Lo único que podrán hacer, en caso de dudas sobre la interpretación de los Tratados o sobre la validez del Derecho derivado respecto de los mismos, será plantear el recurso prejudicial, regulado en el artículo 177 TCEE.

El juez nacional queda, por tanto, encargado de materializar esa primacía. Ello significa que la primacía del Derecho comunitario se traduce en una inmediatez en la aplicación del mismo, que hay que poner en relación con los caracteres de aplicación inmediata y directa que presenta el ordenamiento comunitario.

Veremos a continuación la problemática que ha generado en algunos Estados la primacía del Derecho comunitario, en particular respecto de su relación con la norma nacional posterior, y con los preceptos de los textos constitucionales de los Estados miembros que regulan los derechos fundamentales de sus ciudadanos.

\section{PROBLEMÁTICA EN EL DERECHO COMPARADO}

La primacía del Derecho comunitario sobre los ordenamientos de los Estados miembros no siempre ha sido favorablemente acogida por parte de los Tribunales de los Estados miembros. Concretamente, se han planteado problemas respecto de las relaciones del Derecho comunitario con la ley interna posterior, y también en cuanto a las posibles vulneraciones, por parte de los actos de las instituciones comunitarias, de derechos fundamentales reconocidos en las Constituciones de los Estados miembros.

\section{a) Derecho comunitario y ley nacional posterior}

A propósito de la relación entre el Derecho comunitario y la ley posterior, hay que decir que, en principio, no tendrian que plantearse problemas, ya que, según la jurisprudencia del TJCE,

«...en la medida en que los Estados miembros han atribuido a la Comunidad poderes normativos en materia arancelaria, ...ya no tienen la atribución de promulgar disposiciones normativas en esta materia». ${ }^{27}$

27 TJCE, Sentencia de 18 de febrero de 1970, asunto 40/69, Bollmann, Rec. 1970, págs. 69 y ss. 
Pero podría ocurrir, por ejemplo, que esa contradicción se produjera entre una disposición comunitaria (a propósito de una materia cuya competencia correspondiera a la Comunidad) y una norma interna que la desarrollara (recuérdese, a este respecto, lo dicho en el epígrafe 3 de este trabajo).

Si esa contradicción llegara a existir, la jurisprudencia comunitaria ha dejado claro que el juez nacional ha de aplicar la norma comunitaria. El Tribunal aborda esta cuestión de la relación entre el Derecho comunitario y las reglas nacionales contrarias que se le opongan, en la ya citada sentencia Simmenthal:

«...En virtud del principio de primacia del Derecho comunitario, las disposiciones del Tratado y de los actos de las instituciones directamente aplicables tienen como efecto, en sus relaciones con el Derecho interno de los Estados miembros, no solamente el de convertir en inaplicable de pleno derecho, por el hecho mismo de la entrada en vigor de aquéllas, toda disposición contraria de la legislación nacional existente, sino también en la medida en que estas disposiciones y estos actos son parte integrante, con rango de prioridad, del ordenamiento jurídico aplicable en el territorio de cada uno de los Estados miembros, el de impedir la aprobación lícita de nuevos actos legislativos, en la medida en que fueran incompatibles con las normas comunitarias».

En suma, primacía del Derecho comunitario sobre la ley posterior, y obligación del juez nacional de aplicar, en caso de colisión, la norma comunitaria.

A este respecto, los Tribunales de diversos Estados miembros han mantenido posturas no siempre coincidentes con las expresadas por la Jurisprudencia comunitaria. Nos fijaremos, concretamente, en la postura mantenida en un determinado momento por la Corte Costituzionale italiana ${ }^{28}$. La Corte entendía que el juez nacional no es compe-

28 Aparte de los Tribunales Constitucionales, merece mencionarse la postura del Conseil d'État francés, Tribunal superior en el orden contencioso-administrativo, el cual ha mantenido que el juez debe dar preferencia a la ley nacional posterior. En esta postura permanece latente la idea del juez como mero aplicador de la ley, expresión última de la voluntad popular. El juez se encontraría más fuertemente vinculado por la ley nacional que por un Tratado o una norma procedente de una institución supranacional. De todas formas, la postura del Conseil d'État es un caso aislado con respecto a la tónica general de aceptación de la primacía comunitaria que se observa en los Tribunales nacionales de los Estados miembros. Véase M. R. TORRES HeRnÁNDEZ, "La primacía del Derecho comunitario", op. cit., en nota 24, págs. 19 y ss., a quien seguimos fundamentalmente en esta parte de la exposición. 
tente para inaplicar una ley posterior por ser contraria a la comunitaria. Lo que se suscitaría en estos casos sería un problema de constitucionalidad, pues habría que determinar si el legislador interno ha invadido o no un dominio competencial transferido a la Comunidad de acuerdo con el artículo 11 de la Constitución. Por ello, cuando al juez nacional se le presente un litigio en el que halle contradicción entre ley interna posterior y norma comunitaria, no podrá por sí mismo inaplicar la ley posterior, sino que deberá plantear la cuestión ante la Corte Costituzionale, para que sea ésta quien resuelva. De este modo, la Corte no tiene en cuenta el principio de primacía y mantiene el monopolio de control de las leyes ${ }^{29}$.

El Tribunal de Justicia comunitario ha respondido a estas afirmaciones en la ya citada sentencia Simmenthal, reiterando argumentos que ya conocemos, y refiriéndose al problema planteado utilizando la siguiente argumentación:

"...Sería incompatible con las exigencias inherentes a la naturaleza misma del Derecho comunitario toda imposición de un ordenamiento juridico nacional o toda práctica legislativa, administrativa o judicial que tuviera por efecto disminuir la eficacia del Derecho comunitario por el hecho de no reconocer al juez competente para aplicar este derecho, el poder de hacer, en el momento mismo de esta aplicación, todo lo que es necesario para eliminar las disposiciones legislativas nacionales que constituyan eventualmente obstáculos a la plena eficacia de las normas comunitarias.

Tal sería el caso si en la hipótesis de contradicción entre una disposición del Derecho comunitario y una ley nacional posterior, la solución de este conflicto quedara reservada a una autoridad distinta del juez llamado

Respecto de la actitud del Conseil d'État y del Conseil Constitutionnel hacia el Derecho comunitario, puede verse B. Genevols, "Le Droit international et le Droit Communautaire", en VV.AA., Conseil Constitutionnel et Conseil d'État (Colloque des 21 et 22 janvier 1988, au Sénat), París, Librairie Générale de Droit et de JurisprudenceMontchrestien, 1988, págs. 191-218.

${ }_{29}$ En sentencia de 30 de octubre de 1975, n. 232 (Giurisprudenza Costituzionale, 1975, I, págs. 2211 y ss.), la Corte ha señalado que «...en lo que concierne a las normas internas sucesivas, ...esta Corte sostiene que el ordenamiento vigente no confiere al juez italiano el poder de desaplicarlas en el presupuesto de una general prevalencia del Derecho comunitario sobre el Derecho del Estado..., debiendo excluirse que la transferencia a los órganos de la Comunidad del poder de emanar normas jurídicas, sobre la base de un preciso criterio de reparto de competencias para determinadas materias, lleve como consecuencia una radical privación de los efectos de la voluntad soberana de los órganos legislativos de los Estados miembros...". 
a asegurar la aplicación del Derecho comunitario, investido de un poder de apreciación propio.»

Además, como ya vimos, esta sentencia afirma en otro de sus párrafos que el juez ordinario tiene la obligación de asegurar el pleno efecto de las normas comunitarias, inaplicando en su caso las nacionales, sin pedir o esperar la eliminación de éstas por cualquier procedimiento constitucional. Así, se señala también que

"...las eventuales disposiciones nacionales ulteriores, en contradicción con las normas comunitarias, deben ser consideradas de pleno derecho como inaplicables, sin que sea necesario esperar su eliminación por el propio legislador (derogación) o por otros órganos constitucionales (declaración de inconstitucionalidad), principalmente si se considera, en lo que concierne a la segunda, que hasta que se produzca la declaración en cuestión, la ley nacional permanece plenamente aplicable y que las normas comunitarias no pueden surtir sus efectos, y por tanto, su aplicación plena, entera y uniforme, y no es garantía de los derechos subjetivos particulares nacidos de la situaciónn.

La Corte Costituzionale ha terminado modificando su doctrina jurisprudencial, admitiendo que sea el juez ordinario el encargado de inaplicar las leyes posteriores que se opongan a las normas comunitarias directamente aplicables. Aunque con argumentación particular, ha llegado a conclusiones casi idénticas a las del Tribunal de Justicia comunitario, en la sentencia de 8 de junio de 1984. Esta sentencia, tras exponer las líneas básicas de la jurisprudencia anterior, afirma que es necesario revisar la consideración de la oposición entre reglamento comunitario y ley posterior como un problema de inconstitucionalidad por violación del artículo 11 de la Constitución.

Para ello, la Corte sigue considerando los ordenamientos nacional y comunitario como autónomos y distintos. Pero afirma que ambos ordenamientos deben producir sus efectos cada uno en cuanto tal, sin interferir uno con otro, de acuerdo con la transferencia de competencias realizada por la firma y ejecución de los Tratados, siendo la norma comunitaria la aplicable en caso de conflicto, si la materia a la que afecta corresponde al ámbito competencial comunitario.

Ahora bien, al tratarse de ordenamientos distintos, el juez ordinario no puede apreciar o declarar nulidad alguna, ni tampoco podrá producirse abrogación o cualquier otro efecto extintivo o derogatorio de la norma nacional, con lo cual la ley nacional continúa vigente, aunque sin poder ser aplicada. Lo que el juez ordinario deberá hacer será determinar 
qué norma es la aplicable, sin que tenga relevancia que la ley sea anterior o posterior al reglamento comunitario ${ }^{30}$.

\section{b) Los derechos fundamentales}

La que acabamos de estudiar no es la única disconformidad que se ha registrado acerca de las relaciones entre Derecho comunitario $y$ Derecho interno. Los problemas se han suscitado, sobre todo, en materia de derechos fundamentales. Se ha planteado si, a falta de un catálogo expreso de derechos fundamentales en los tratados comunitarios, hay que entender los derechos reconocidos en los textos constitucionales de los Estados miembros como un límite a la primacía del Derecho comunitario.

En efecto, y a diferencia de lo que es habitual en las Constituciones de los Estados miembros, los tratados comunitarios no disponen de un catálogo de derechos que permita a los ciudadanos valerse de los mismos frente a los actos $y$ disposiciones emanadas de las instituciones y órganos comunitarios. Se ha planteado, en definitiva, la pregunta sobre si en la Comunidad Europea están protegidos los derechos fundamentales, cuyo respeto se considera un elemento legitimador del poder estatal.

La ausencia de un catálogo de derechos en los tratados comunitarios extraña especialmente si se tiene en cuenta que los sujetos del Derecho comunitario no son sólo los Estados miembros, sino también sus ciudadanos $^{31}$.

En realidad, la explicación podría encontrarse en el hecho de que las competencias de la Comunidad revisten un carácter predominantemente socioeconómico. Pero es que, aun dejando aparte la cuestión de si

30 Corte Costituzionale, sentencia de 8 de junio de 1984, n. .170 , Giurisprudenza Costituzionale, l, 6/1984, págs. 1098 y ss. Acerca de esta decisión, véase P. PÉREZ Tremps, "Justicia comunitaria, Justicia constitucional y Tribunales ordinarios frente al Derecho comunitario. (Comentario a la Sentencia de la Corte Constitucional italiana número 170/1984, de 8 de junio)", Revista Española de Derecho Constitucional, año 5, n. 13, enero-abril 1985, págs. 157-181.

${ }^{31}$ Así lo pone de manifiesto J. A. CaRRILlo SALCEDo, "La protección de los Derechos humanos en las Comunidades Europeas", en VV.AA. (dirigidos por E. GaRciA de Enterría, J. D. González Campos y S. Muñoz Machado), Tratado de Derecho comunitario, Madrid, Civitas, 1986, vol. IIl., págs. 17-26. 
los derechos económicos y sociales están suficientemente reconocidos, protegidos y respetados en el ámbito comunitario, no debe en absoluto excluirse la posibilidad de que algún acto de las instituciones u órganos de la comunidad pueda vulnerar derechos o libertades individuales de los considerados "fundamentales", más aún cuando los Estados van transfiriendo cada vez más competencias a las Comunidades, y la finalidad económica originaria va ampliándose también paulatinamente, en camino hacia una unión política.

De todas formas, aunque no exista un catálogo de derechos fundamentales, hay que decir que la laguna no es total, pues existen algunos preceptos, contenidos en los tratados comunitarios, que de una $u$ otra forma hacen referencia a esos derechos ${ }^{32}$.

Respecto de este tema, ante el riesgo de que los Tribunales Constitucionales quisieran hacer prevalecer las garantías constitucionales previstas en sus respectivos ordenamientos jurídicos, el Tribunal de Justicia ha reafirmado la primacía absoluta del Derecho comunitario, en relación con el carácter que éste presenta de ordenamiento autónomo respecto del estatal.

Así, en la sentencia International Handelsgesellschaft, afirmó:

"...La invocación de violaciones realizadas, bien a los derechos fundamentales, tal como son formulados por la Constitución de un Estado miembro, bien a los principios de una estructura constitucional nacional, no podría afectar a la validez de un acto de la Comunidad o a su efecto directo sobre el territorio de ese Estadon" ${ }^{33}$.

32 Por ejemplo, el artículo 7 TCEE señala que «en el ámbito de aplicación del presente Tratado (...), se prohibirá toda discriminación por razón de nacionalidad". En el artículo 48 TCEE, esta no discriminación aparece con relación a la libre circulación de trabajadores. El artículo 119 del mismo Tratado establece el principio de igualdad de retribución por el mismo trabajo para hombres y mujeres. La propiedad industrial y comercial se protege en el artículo 36 TCEE; los artículos 118.1 TCEE y 46.2 TCECA hablan de la promoción de los derechos sindicales básicos; el artículo 214 alude al secreto profesional, etc. Se trata, sin embargo, salvo excepciones, de derechos de carácter socioeconómico, de acuerdo con la finalidad originaria de la Comunidad. Así, en la segunda parte del Tratado se dedican sucesivos títulos a la libre circulación de mercancías, personas, servicios y capitales, estando la tercera parte dedicada a la política de la Comunidad, en sus vertientes económica, social, tecnológica y medioambiental. A la garantía de tales derechos se refieren genéricamente los artículos 164 y ss. TCEE, a propósito de las competencias del Tribunal de Justicia.

${ }_{33}$ TJCE, sentencia de 17 de diciembre de 1970, asunto 11/70, International Handelsgesellschaft, Rec. 1970, pág. 1135. 


\section{Y en la sentencia Hauer reafirmó que}

"...la cuestión relativa a una eventual violación de los derechos fundamentales por un acto institucional de las Comunidades no podría apreciarse más que en el marco del propio Derecho comunitario. La introducción de criterios de apreciación particulares, procedentes de la legislación o del ordenamiento constitucional de un Estado miembro determinado, al suponer violación de la unidad material y eficacia del Derecho comunitario, tendría ineluctablemente por efecto romper la unidad del Mercado Común y hacer peligrar la cohesión de la Comuni$\operatorname{dad} 13^{34}$.

A esta doctrina del Tribunal de Justicia se opuso el Tribunal Constitucional federal alemán, en respuesta a la sentencia International Handelsgesellschaft, y a requerimiento de un tribunal de Franckfurt, en su famosa sentencia de 29 de mayo de 1974.

Mantiene aquí el Tribunal alemán que la transferencia de competencias operada en virtud del artículo 24 de la Constitución debe entenderse e interpretarse dentro del contexto del propio texto constitucional. Además, se considera a los derechos fundamentales "un elemento inalienable de la Constitución", y se les da aplicación preferente.

El Tribunal Constitucional Federal alemán, en esta sentencia, aunque no estimó que hubiera existido vulneración de Derechos fundamentales, sí estableció la posibilidad de conocer de este tipo de asuntos (fijando asi una excepción a su anterior línea jurisprudencial, consistente en declararse incompetente para juzgar sobre la constitucionalidad de las normas comunitarias) y puso como condición a la aceptación de la primacía la existencia de una Declaración de derechos dentro de las Comunidades:

«...En tanto que el proceso de integración en la Comunidad no haya alcanzado el estadio en que el Derecho comunitario esté dotado también de un catálogo vigente de derechos fundamentales establecidos por un Parlamento, iguales al catálogo de derechos fundamentales que contiene la Constitución, la consulta planteada por un tribunal de la República Federal Alemana ante el Tribunal Constitucional Federal, después de producida la decisión del Tribunal de las Comunidades, de acuerdo con el artículo 177 del Tratado, es admisible y pertinente, si el Tribunal considera inaplicable el precepto comunitario relevante para su decisión en

34 TJCE, sentencia de 13 de diciembre de 1979, asunto 44/79, Hauer, Rec. 1979, pág. 3744. 
la interpretación dada por el Tribunal de las Comunidades en la medida en que colisione con uno de los derechos consagrados por la Ley Fundamental» ${ }^{35}$.

Lo que ocurre es que la preocupación de los Tribunales Constitucionales sólo se ha planteado de forma teórica. En efecto, a pesar de que los Tratados constitutivos no cuentan con una declaración de derechos, el Tribunal de Justicia de la Comunidad ha ido protegiendo éstos frente a las actuaciones de la Comunidad, considerándolos un límite a las mismas ${ }^{36}$.

En efecto, el Tribunal de Justicia de las Comunidades ha llevado a cabo una labor jurisprudencial encaminada a una suficiente protección de los derechos fundamentales.

Para ello ha utilizado, fundamentalmente, dos mecanismos:

- En primer lugar, según ha establecido en la citada sentencia International Hande/sgesellschaft,

"...el respeto de los derechos fundamentales es parte integrante de los principios generales del Derecho cuyo respeto asegura el Tribunal... ${ }^{37}$

35 Véase M. R. Torres Hernández, "La primacía del Derecho comunitario", op. cit., en nota 24, pág. 22. Asimismo, P. Pérez TREMPS, "Justicia comunitaria, Justicia constitucional y Tribunales ordinarios frente al Derecho comunitario (Comentario a la Sentencia de la Corte Constitucional italiana número 170/1984, de 8 de junio)", op. cit., en nota 30 , págs. 172-173. Cita aquí este autor, asimismo, la sentencia de 27 de diciembre de 1973 (n.o 183/1983, Giurisprudenza Costituzionale, 1973, I, págs. 2401 y ss.), de la Corte Costituzionale italiana, la cual establece que en algunos supuestos extraordinarios no podría aceptarse la prevalencia del Derecho comunitario. Se trataría de aquellos casos "aberrantes" en los que el Derecho comunitario choque con principios fundamentales inmodificables de la Constitución o con derechos fundamentales; doctrina que ha sido confirmada por la sentencia de 8 de junio de 1984.

36 P. Pérez Tremps, ibidem, pág. 173.

37 Esta misma doctrina se ha recogido, asimismo, en la también citada sentencia Hauer: "...El Tribunal ha subrayado asimismo, en la sentencia citada, y posteriormente, en la sentencia de 14-V-1974, Nold, que los derechos fundamentales constituyen parte integrante de los principios generales del Derecho cuyo respeto asegura; que, al asegurar la protección de estos derechos, se inspira en las tradiciones constitucionales comunes a los Estados miembros, de forma que no pueden admitirse en la Comunidad medidas incompatibles con los derechos fundamentales reconocidos por las Constituciones de estos Estados». El Tribunal de Justicia realiza esta afirmación en reiterada jurisprudencia: sentencia de 14 de mayo de 1974. asunto 4/73, Nold; sentencia de 26 de junio de 1980, asunto 136/79, National Pana- 
...La protección de estos derechos, al inspirarse en las tradiciones constitucionales comunes a los Estados miembros, debe ser asegurada en el marco de la estructura y objetivos de la Comunidad."

Vemos, así, que el Tribunal, si bien no aplica las normas constitucionales de los Estados miembros como tales, si tiene en cuenta los derechos establecidos en las Constituciones nacionales, para obtener un denominador común, que pasa, junto con la idea del respeto de esos derechos, a formar parte de los principios generales del Derecho comunitario. Así, utiliza el Tribunal la noción de uprincipios generales del Derecho", que recuerda a la mención que a los mismos realiza el artículo 38 del Estatuto del Tribunal Internacional de Justicia de las Naciones Unidas.

Pero el Tribunal va más allá al afirmar que la protección de los derechos debe ser asegurada en el marco de la estructura y objetivos de la Comunidad. Es cierto que esta afirmación del Tribunal puede ser interpretada como un límite: se trata sólo de derechos que afecten a la estructura y objetivos de la Comunidad, y sólo en la medida en que afecten a ellos deben ser protegidos ${ }^{38}$.

Además, parece que lo que el Tribunal trata de hacer es elevar la protección de los derechos a los que puedan afectar las competencias comunitarias, al rango de objetivo comunitario. Hemos visto cómo los fines y objetivos de la Comunidad están siempre presentes en la jurisprudencia del Tribunal y son la razón de ser del sistema jurídico comunitario y sus peculiares características. Pues bien: los dos párrafos transcritos, interpretados conjuntamente, parecen conducirnos a la conclusión de que la intención del Tribunal es convertir el respeto a los derechos fundamentales de los ciudadanos, y la protección de los mismos, en uno más de esos fines $y$ objetivos en torno a cuya consecución gira todo el sistema ${ }^{39}$.

sonic; sentencia de 17 de octubre de 1989, asuntos 97, 98 y 99/87, Dow Chemical Iberica, S. A.; Alcudia, S. A., y Empresa Nacional del Petróleo/Comisión de las Comunidades Europeas. Esta doctrina ha encontrado el apoyo del resto de las instituciones en la Declaración conjunta del Parlamento, Consejo y Comisión, de 5 de abril de 1977, DOCE n.․ C 103, de 27 de abril de 1977, pág. 1.

38 M. R. ToRRES HeRNÁNDEZ, "La primacía del Derecho comunitario", op. cit., en nota 24, pág. 21.

39 Además, esa consideración de los derechos fundamentales como integrantes de los principios generales del Derecho comunitario hace actuar a estos Derechos como límites para determinar la validez de las disposiciones comunitarias. Así se puede apreciar en la sentencia de 12 de noviembre de 1969, asunto 29/69, Stauder, donde el Tribunal entra a valorar que «...la disposición litigiosa no revela 
- Como segundo mecanismo, el Tribunal ha establecido cuáles son esos derechos protegibles, a falta de un catálogo de los mismos en los Tratados.

Para ello, por una parte, ha interpretado extensivamente las disposiciones de los tratados que de alguna manera se refieren a derechos fundamentales ${ }^{40}$.

Pero el Tribunal no se ha limitado a esta interpretación extensiva de los tratados, sino que, además, para la protección de los derechos, se inspira en los catálogos de los textos constitucionales de los Estados miembros -extrayendo unos principios generales comunes a los mismos- y en las Declaraciones y Convenios sobre esta materia suscritos por éstos. Así, en la sentencia Nold:

«...Al asegurar la protección de estos derechos, el Tribunal debe inspirarse en las tradiciones constitucionales comunes a los Estados miembros, y no puede, por ello, admitir medidas incompatibles con los derechos fundamentales reconocidos y garantizados por las Constituciones de estos Estados;

...Los instrumentos internacionales, relativos a la protección de los derechos del hombre en que han cooperado los Estados miembros o a los que se han adherido, pueden, asimismo, proporcionar indicaciones que conviene tener en cuenta en el marco del Derecho comunitario."

En particular, el convenio utilizado para esta integración ha sido el Convenio Europeo para la salvaguardia de los derechos humanos y de las libertades fundamentales ${ }^{41}$.

ningún elemento susceptible de hacer peligrar los derechos fundamentales de la persona comprendidos en los principios generales del Derecho comunitario, cuyo respeto asegura el Tribunal". Igualmente, la citada sentencia Nold afirma que el Tribunal «no puede, por ello, admitir medidas incompatibles con los derechos fundamentales reconocidos y garantizados por las Constituciones de estos Estados". Véase P. Pérez Tremps, "Justicia comunitaria, Justicia constitucional y Tribunales ordinarios frente al Derecho comunitario. (Comentario a la Sentencia de la Corte Constitucional italiana número 170/1984, de 8 de junio/", op. cit., en nota 30 , pág. 173.

40 P. Pérez Tremps, ibidem, pág. 174.

41 Convenio de Roma, 4-XI-1950, del que España es parte desde 1979. La citada sentencia Dow Chemical ibérica... de 17 de octubre 1989 cita expresamente este convenio. Véase también la sentencia de 15 de mayo de 1986, asunto 222/84, Johnston, Rec. 1984, pág. 1651. Sobre la utilización de este convenio por el Tribunal de Justicia, y las referencias doctrinales de la discusión sobre si ha llegado o no a formar parte del Derecho comunitario, véase J. A. CARRILlo SALCEDo, "La protección 
Esta favorable disposición del Tribunal de Justicia y su positiva actitud a la hora de rellenar la laguna relativa a los derechos fundamentales ha motivado que la primacía del Derecho comunitario haya sido aceptada, también en esta materia, por los Tribunales Constitucionales de los Estados miembros ${ }^{42}$.

En resumen, puede considerarse, con PÉREZ TREMPS, que el Tribunal de Justicia desarrolla una importante labor de defensa de derechos fundamentales, de forma que la actuación de instancias nacionales puede obviarse. Y ello por el juego que proporciona la cuestión prejudicial recogida en el artículo 177 TCEE. En efecto, el juez nacional que deba apli-

de los Derechos humanos en las Comunidades Europeas", op. cit., en nota 31, págs. 21 y ss. Este autor mantiene que no se ha producido esa incorporación del convenio al Derecho comunitario. Prueba de ello es que, tras la Declaración común de 5 de abril de 1977, la Comisión de las Comunidades dirigió un memorándum a las demás instituciones, en abril de 1979, acerca de la posibilidad de adhesión de las Comunidades a la Convención Europea de Derechos Humanos. La solución que, ante los problemas planteados, ofrece este autor, es la adhesión de las Comunidades (como sujeto de Derecho internacional con personalidad propia, distinta y separada de la de los Estados miembros) a la parte normativa de la Convención Europea y de sus protocolos adicionales, pero no al mecanismo de garantía y control -el Tribunal Europeo de Derechos Humanos- instituido en la Convención. En cualquier caso, la diversidad de las regulaciones constitucionales al respecto hace difícil la elaboración de un catálogo de derechos propio. Véase también, sobre esta problemática, y en particular sobre las dificultades de creación de un catálogo propio, I. Lasagabaster Herrarte, "Las Comunidades Europeas y los derechos fundamentales", Revista Española de Derecho Constitucional, año 6, n.․ 18, septiembrediciembre 1986, págs. 51-82, concretamente págs. 77 y ss.

42 Así, se produce a partir de 1981 un giro en la jurisprudencia del Tribunal constitucional alemán, concretamente en su sentencia de 23 de junio de 1981, Eurocontrol, donde, si bien se trata de un asunto no propiamente comunitario, se observa una desaparición de las reticencias hacia la primacia del Derecho de una organización internacional, aun reconociendo que es casi imposible pedir una idéntica protección de los derechos en el ámbito nacional y en el comunitario: «Una concordancia absoluta entre la estructura jurídica de una organización internacional y las disposiciones internas de un Estado miembro se opondría, en último término, a la opción constitucional en favor de la cooperación internacional... y convertiría a la República Federal de Alemania en incapaz para concluir acuerdos en el seno de aquellas organizaciones internacionales a las que se hace referencia en el artículo 24 de la Ley Fundamental" (citado por M. R. Torres Hernández, "La primacía del Derecho comunitarion, op. cit., en nota 24, pág. 22). Esta tendencia parece asentada a raíz de la sentencia del Tribunal Constitucional alemán de 22 de octubre de 1986.

Ya en el auto 6/1979, de 25 de julio, el Tribunal alemán había considerado suficiente el nivel de protección de los derechos fundamentales por parte de la Comunidad (citado por P. PÉrez Tremps, "Justicia comunitaria, Justicia constitucional y Tribunales ordinarios frente al Derecho comunitario (Comentario a la Sentencia de la Corte Constitucional italiana número 170/1984, de 8 de junio)", op. cit., en nota 30, pág. 179). 
car una norma comunitaria que considere contraria a los derechos fundamentales - principios generales del ordenamiento comunitario- ha de acudir al Tribunal de Justicia de la Comunidad, utilizando esta vía para que éste aprecie la regularidad o no de dicha norma ${ }^{43}$.

\section{ANÁLISIS DE LA PRIMACÍA EN RELACIÓN CON EL ORDENAMIENTO CONSTITUCIONAL ESPAÑOL}

Para el estudio de las relaciones entre el Derecho español y el ordenamiento comunitario, y de la primacía de éste, son útiles en buena medida las consideraciones realizadas con carácter general en los epígrafes anteriores.

\section{a) Derecho comunitario y sistema de fuentes}

Cabe en este punto referirse brevemente a la posición que ocupa en nuestro ordenamiento el Derecho internacional general, y en concreto los tratados internacionales.

La consideración de los tratados como auténtica fuente del Derecho viene afirmada por el primer inciso del artículo 96.1 del texto constitucional:

43 P. Pérez Tremps, ibidem, pág. 174.

El artículo 177 TCEE establece: prejudicial:

«El Tribunal de Justicia será competente para pronunciarse, con carácter

a) Sobre la interpretación del presente Tratado;

b) Sobre la validez e interpretación de los actos adoptados por las instituciones de la Comunidad;

c) Sobre la interpretación de los estatutos de los organismos creados por un acto del Consejo, cuando dichos estatutos asi lo prevean.

Cuando se plantee una cuestión de esta naturaleza ante un órgano jurisdiccional de uno de los Estados miembros, dicho órgano podrá pedir al Tribunal de Justicia que se pronuncie sobre la misma, si estima necesaria una decisión al respecto para poder emitir su fallo.

Cuando se plantee una cuestión de este tipo en un asunto pendiente ante un órgano jurisdiccional nacional, cuyas decisiones no sean susceptibles de ulterior recurso judicial de Derecho interno, dicho órgano estará obligado a someter la cuestión al Tribunal de Justicia.» 
"Los tratados internacionales válidamente celebrados, una vez publicados oficialmente en España, formarán parte del ordenamiento interno" ${ }^{44}$

Admitida su condición de norma jurídica integrante del ordenamiento, sólo resta, entonces, determinar su posición dentro del mismo.

Si bien en el Anteproyecto constitucional se reconocía a los tratados una posición jerárquicamente superior a las leyes, la Constitución no resuelve la cuestión de forma expresa.

- En cuanto a la posición que ocupan los tratados respecto de las leyes, hay que decir que ambos pueden ser objeto de control de constitucionalidad según el artículo 27.2 de la Ley Orgánica del Tribunal Constitucional, por lo que este dato no nos revela una diferente posición en el sistema de fuentes.

En favor de una posición jerárquicamente superior de los tratados, puede argumentarse la fuerza pasiva de que éstos gozan respecto de las leyes de acuerdo con el artículo 96.1: los tratados no pueden ser derogados, modificados o suspendidos por leyes estatales, sino sólo «en la forma prevista en los propios tratados o de acuerdo con las normas generales del Derecho internacional» ${ }^{45}$.

44 Tal y como señala E. ÁlvAREz CONDE (El régimen político español, Madrid, Tecnos, 4. a edición, 1990, págs. 283-285), a quien seguimos fundamentalmente en este punto, el artículo 96.1 sigue las pautas del artículo 1.5 del Código Civil, incorporando el sistema de la recepción automática de los tratados lla exigencia de publicación no tiene carácter constitutivo, por lo que afecta sólo a su eficacia, pero no a su validez). Señala este autor que la opción por el sistema de recepción automática dificulta la determinación de la posición de los tratados en el sistema de fuentes: si no se hubiera optado por este sistema, el tratado tendría el rango normativo que correspondiese a la forma que efectuase su incorporación al Derecho interno.

Por otra parte, los tratados ratificados por España en materia de derechos fundamentales desempeñan una importante función interpretativa en los términos del artículo 10.2 de la Constitución.

El Tribunal Supremo, en numerosas sentencias, se ha ocupado de la eficacia interna de los tratados aplicando los artículos 94 a 96 . Véanse, por ejemplo, las sentencias de 12 de diciembre de 1980 (Sala 1.a), 22 de septiembre y 3 de noviembre de 1981 (Sala 4.a ), 3 de diciembre de 1981 (Sala 3.a), 8 de julio y 30 de septiembre de 1982 (Sala 3.a). Los pronunciamientos que al respecto ha realizado el Tribunal Constitucional están en relación, sobre todo, con el Derecho comunitario europeo, por lo que nos referiremos a ellos más adelante.

45 En tal sentido, E. Álvarez Conde, ibidem, pág. 285. Asimismo, este autor distingue los tratados que requieren intervención del Parlamento y los que no la requieren, afirmando claramente la superioridad sobre las leyes solamente respecto de aquéllos. En cualquier caso, afirma que el principio para dar solución al 
No faltan, sin embargo autores que, para explicar la relación entre ley y tratado, prefieren acudir al principio de competencia, como si hubiera bloques competenciales distintos que incumbieran, respectivamente a los convenios internacionales o a las normas estatales ${ }^{46}$.

La ausencia de esos dos bloques competenciales diferenciados, junto con la fuerza pasiva de que gozan los tratados respecto de las leyes, son los argumentos que nos llevan a pronunciarnos en favor de la utilización del criterio jerárquico para responder a la cuestión que nos ocupa. En caso de contradicción entre un tratado y una ley interna, deberá darse aplicación preferente al tratado, y ello revela, en nuestra opinión, una posición de superioridad jerárquica ${ }^{47}$.

tema de la relación entre las leyes y los tratados sería el de jerarquía, y no el de competencia.

Por su parte, I. DE OTTO, Derecho Constitucional. Sistema de fuentes, BarceIona, Ariel, 2..$^{a}$ edición, 1988, pág. 126, señala que estamos ante una relación sui generis, que no debe reducirse sin más al principio de jerarquía, sino que debe ser explicada a partir de la naturaleza misma de los tratados: el tratado se aplicará por encima de la ley en virtud del principio pacta sunt servanda.

${ }_{46}$ Asi, para T. R. Fernández, en E. García de Enterría y T. R. Fernández, Curso de Derecho Administrativo, vol. I, 5. edición, Madrid, Civitas, 1989, pág. 172, del artículo 96 no puede deducirse una posición jerárquicamente superior de los tratados (punto que fue expresamente rectificado en la tramitación parlamentaria del texto constitucional), sino que el principio aplicable es el de competencia: «La materia cubierta por los Tratados y Convenios internacionales suscritos por España queda acotada como una esfera autónoma más dentro de nuestro concreto sistema de fuentes y sometida a un tratamiento procesal específico, el propio del Derecho internacional (...), tratamiento que la defiende frente a eventuales invasiones por cualesquiera otros tipos de normas legales cuyo ámbito operativo se circunscribe a bloques de materias diferentes y separados".

No es esto lo que parece desprenderse de la lectura del artículo 94, en el cual aparecen enumeradas competencias no precisamente sustraídas a la potestad normativa estatal (defensa, integridad del Estado, etc).

Más acertada nos parece la postura mantenida por J. Rodriguez-ZAPATA y PÉrez ("Derecho internacional y sistema de fuentes del Derecho: la Constitución española", en La Constitución española y las fuentes del Derecho, Madrid, Dirección General de lo Contencioso del Estado, Instituto de Estudios Fiscales, 1979, vol. III, págs. 17331770 , concretamente págs. 1763 y ss.). Este autor acoge también, aunque de forma más matizada, el principio de competencia como criterio de solución. Califica a los tratados como fuente de fuentes, cuya relevancia en nuestro sistema reviste una gran complejidad, tratándose de un problema de competencia, "en el sentido de que una materia cubierta por un tratado o convenio internacional queda automáticamente sustraída a la intervención normativa unilateral del Estado en todo aquello que suponga modificación, suspensión o derogación de la normativa adoptada".

${ }^{47}$ En tal sentido, F. Santaolalla López, "Los Tratados como fuente del Derecho en la Constitución", en La Constitución española y las fuentes del Derecho, op. cit., en nota 46, vol. III, págs. 1909-1938, concretamente pág. 1922, quien señala que esta solución la proporciona indirectamente el artículo 96.1 de la Constitución. 
- La relación entre los tratados y la Constitución aparece delimitada en el artículo 95.1 del texto constitucional, que establece un control previo de constitucionalidad sobre los tratados internacionales: "La celebración de un tratado internacional que contenga estipulaciones contrarias a la Constitución exigirá la previa revisión constitucional".

Este artículo ha servido para la afirmación por algunos autores del sometimiento de los tratados a la Constitución, y parece que ésta fue la intención del constituyente. Los tratados ocuparian, asi, una posición intermedia entre la Constitución y las leyes. Tal y como señala F. SANTAOLALLA, si la conclusión de un tratado que resulte contrario a la Constitución exige la previa revisión de ésta, ello supone que aquél no puede modificarla directamente y que, por tanto, se trata de una norma subordinada ${ }^{48}$.

Por otra parte, no hay que olvidar que los tratados están también sujetos a control de constitucionalidad a posteriori, de acuerdo con el artículo 27.2.c) de la Ley Orgánica del Tribunal Constitucional ${ }^{49}$.

48 F. Santaolalla lópez, ibidem, pág. 1924. En el mismo sentido, J. RodríguezZaPATA y PÉREZ, "Derecho internacional y sistema de fuentes del Derecho: la Constitución española", op. cit., en nota 46, pág. 1764. Por su parte, T. R. Fernández Rodriguez, en E. Garcia de Enterría y T. R. Fernández, Curso de Derecho Administrativo, op. cit., en nota 46, pág. 172, observando el problema desde el punto de vista del principio de competencia, señala que no puede hablarse, a la vista de los artículos 93 y 95, de una supraconstitucionalidad de los tratados. En efecto, tal y como señala este autor, con el artículo 93 "se evita $a b$ initio cualquier posible colisión futura entre el Tratado y la Constitución. Y, en virtud del artículo 95, el tratado "habrá de moverse siempre en el marco de la Constitución".

${ }_{49}$ Véase, al respecto, J. RodRiguez-ZAPATA Y PÉrez, "Los tratados internacionales y los controles de constitucionalidad", en El Tribunal Constitucional, Madrid, Dirección General de lo Contencioso del Estado, Instituto de Estudios Fiscales, 1981, págs. 2361-2410. Asimismo, A. Remiro Brotons, "Controles preventivos y reparadores de la constitucionalidad intrínseca de los tratados internacionales", Revista de Derecho Político, n. 16, invierno 1982-1983, págs. 109-141.

Para mayor información sobre la integración del Derecho internacional en el Derecho interno español y la posición de aquél respecto de la Constitución y de las leyes, puede verse el trabajo de J. L. ReQuejo PAGES, "Consideraciones en torno a la posición de las normas internacionales en el ordenamiento español", Revista Española de Derecho Constitucional, n. 34, enero-abril 1992, págs. 41-66.

En relación con todas estas consideraciones hay que añadir que la creciente cooperación internacional en todos los órdenes hace cada vez más necesaria la consideración del Derecho internacional como fuente prevalente de Derecho, aunque una argumentación que se base en nuestro derecho positivo lleve, como acabamos de ver, a afirmar el sometimiento de los tratados a la Constitución. La diaria 
De todas formas, si ésta es la conclusión a la que debe llegarse con carácter general respecto del Derecho internacional convencional, no parece que pueda afirmarse con tanta claridad la supremacía de la Constitución cuando se trata de la integración en organizaciones supranacionales.

De estos supuestos, como sabemos, se ocupa el artículo 93 del texto constitucional, y en él se habla de "atribución de competencias derivadas de la Constitución".

Parece que, cuando se trata de organizaciones supranacionales, sí entra en juego el principio de competencia, en el sentido de que, en las materias transferidas, la Constitución efectúa una cesión de su carácter supremo, y es el derecho emanado por la organización el que debe considerarse prevalente. No es posible otra conclusión si tenemos en cuenta que, como señalábamos anteriormente, este tipo de organizaciones vienen a dar solución, en un clima de cooperación internacional, a problemas respecto de los cuales los Estados no pueden mantener una posición de aislamiento.

Esto es to que sucede, por ejemplo, con la Comunidad Europea. Precisamente, el artículo 93 de la Constitución se redactó pensando en la ya previsible incorporación de nuestro país a las mismas.

Por eso, lo dicho con carácter general en epígrafes anteriores sobre la posición de primacía que ocupa el Derecho comunitario respecto del Derecho interno es plenamente aplicable al caso español.

En efecto, la atribución de competencias prevista en el artículo 93 de la Constitución supone una limitación a la supremacía constitucional, en las materias objeto de la cesión. La adhesión de España a las Comunidades ha supuesto la aceptación de lo que se ha dado en llamar uacervo comunitario", el cual incluye los principios y caracteres del Derecho comunitario (elaborados en buena parte por la jurisprudencia del TJCE), entre los que se encuentra la primacía.

De estas consideraciones, y de las peculiares características del Derecho comunitario se desprende que, en materias de competencia comunitaria, el Derecho comunitario originario o derivado es derecho apli-

realidad de nuestras relaciones internacionales lleva a afirmar la creciente importancia del derecho internacional: existe una auténtica avalancha de tratados $y$ acuerdos que se incorporan a nuestro ordenamiento, sin que en ningún caso hasta 1992 haya sido aplicado el artículo 95. ¿Puede hablarse, a la vista de esta realidad, de una supremacía de facto de los tratados respecto de la Constitución? 
cable en España, para el Estado y para sus ciudadanos, y prevalece sobre cualquier norma interna, incluso sobre la norma constitucional. Como sabemos, la primacía debe ser asegurada por los jueces, los cuales deberán aplicar el Derecho comunitario en lugar de la norma interna que se le oponga. Nos remitimos a la jurisprudencia del Tribunal de Justicia comunitario citada en epígrafes anteriores ${ }^{50}$.

Puesto que el artículo 93 se incluyó pensando en la incorporación de España a las Comunidades Europeas, cabe pensar que el mismo recoge ya implícitamente la aceptación de la primacía del Derecho comunitario. La técnica empleada —previsión de atribución de ámbitos competenciales- implica que los ámbitos regulados por el Derecho comunitario

50 Sobre la incidencia del Derecho comunitario en nuestro sistema de fuentes y la problemática pormenorizada de su aplicación, véase J. Juste RuIz, "La aplicación del Derecho comunitario europeo y la Constitución española de 1978n, en W.AA. (ed: E. Álvarez CoNDE), Diez años de régimen constitucional, Madrid, Tecnos, 1989, págs. 273-298. Se habla aquí del Derecho comunitario como un "derecho de integración", de carácter supranacional, cuya aplicación requiere una activa colaboración de los Estados miembros. Tal y como señala este autor, la Constitución española, en loable actitud de apertura internacionalista, sentó las bases, en el artículo 93, para posibilitar la transferencia de competencias a las instituciones europeas y la garantía del cumplimiento de la normativa comunitaria. Aborda este autor los problemas de la adaptación del Derecho interno - anterior y posterior- al Derecho comunitario, la Ley 47/1985, de 27 de diciembre, de Bases de delegación al Gobierno para la aplicación del Derecho de las Comunidades Europeas - «B.O.E." de 30 de diciembre de 1985-, etc.

Véase asimismo, sobre estas materias, E. Alonso GaRCiA, "La incidencia de la entrada en las Comunidades Europeas en el sistema constitucional de fuentes del Derecho", en VV.AA. (coord: L. AGUIAR DE LUQUE), Implicaciones constitucionales $y$ políticas del ingreso de España en la CEE y su incidencia en las Comunidades Autónomas, Actas del V Congreso de la Asociación Española de Ciencia Política y Derecho Constitucional, Bilbao y San Sebastián, 9-11 de octubre de 1985, págs. 123152. Asimismo, A. Elvira Perales, "Tribunales estatales y Tribunal de Justicia de las Comunidades en la resolución de conflictos entre el Derecho interno y el Derecho comunitario", ibidem, págs. 153-160, y M. V. GARCIA ATANCE, "Las fuentes del ordenamiento jurídico español y su relación con el sistema comunitario de fuentes", ibidem, págs. 161-172. Igualmente, P. PÉrez TrEMPS, "Ordenamiento comunitario y control de las fuentes del derecho", ibidem, págs. 183-205.

Obsérvese, como ejemplo en el que se manifieste la primacía del Derecho comunitario sobre la norma constitucional, el hecho de que una hipotética reforma de la Constitución en materia económica no podría ser contraria a los objetivos comunitarios, en torno a los cuales gira, como sabemos, todo el sistema (asi lo ha puesto de relieve M. BAssols COMA, intervención sobre "La Constitución económica", Congreso sobre La reforma constitucional en España, La Rioja, 27-30 de abril de 1992, publicado en Revista de Derecho Político $n .^{\text {os }} 36-37$. Véanse, sobre los objetivos comunitarios y sobre la intervención de las instituciones comunitarias en estos supuestos, el ya citado artículo 5 y los artículos 169 y ss. TCEE. 
originario y derivado se rigen por las normas comunitarias, con las exigencias incondicionales del sistema comunitario ${ }^{51}$.

También el artículo 96, que, como veíamos, servía para fundamentar la prevalencia de los tratados internacionales sobre las leyes estatales, constituye un argumento más para afirmar la primacía del Derecho comunitario, en este caso sobre las leyes españolas. Con ello, vemos que la primacía no se refiere sólo a los tratados comunitarios, sino también a los actos de las instituciones: sólo podrán ser derogados, modificados o suspendidos por otros actos comunitarios.

Y en cuanto al artículo 95, que antes nos servía para afirmar la prevalencia de la Constitución sobre los tratados, podría plantearse si cumple la misma función cuando se trata de textos que se pretendan ratificar en el seno de organizaciones supranacionales a las que se han cedido "competencias derivadas de la Constitución" en virtud del artículo 93. Puesto que en estos casos se ha producido una cesión de soberanía en determinadas materias, es claro que un tratado que regule esas materias en el marco de una organización supranacional, ocupará una posición prevalente respecto de la Constitución. Parece, entonces, que el artículo 95 vendría en estos casos a posibilitar una adaptación de la Constitución a un tratado que contuviera cláusulas contrarias a la misma: si se quiere ratificar un tratado a pesar de contener disposiciones contrarias a la Constitución, habrá que reformar la Constitución antes de que ese tratado obligue al Estado español, para que no existan supuestos de colisión entre ambas normas.

51 A. Ruiz Robledo, «El ordenamiento jurídico europeo y el sistema de fuentes español», Revista de Derecho Político, n. 32, 1991, págs. 29-54, concretamente págs. 35 y ss., señala que «el artículo 93 es, materialmente, un procedimiento especial de reforma constitucional». En efecto, "de no existir el artículo 93, el carácter de norma suprema de la Constitución impediría que se integraran en el ordenamiento jurídico español disposiciones contrarias a ella, como muy bien se encarga de especificar el artículo 95, exigiendo la previa reforma constitucional para celebrar un tratado internacional con estipulaciones contrarias a la Constitución". Añade este autor que la especial naturaleza de la Comunidad Europea motivó que fuera suprimido en el proceso constituyente el requisito que establecía el artículo 86 del proyecto constitucional, en el sentido de que la atribución de competencias a organizaciones internacionales se hiciera a "condición de paridad con los demás Estados" o a "reserva de reciprocidad", como sí sucede, por ejemplo, en el artículo 11 de la Constitución italiana o en el artículo 20 de la danesa. En definitiva - señala Ruiz Robledo citando a Mangas Martín-, el artículo 93 funcionaría como lex specialis respecto a la norma general del artículo 96. Por otra parte, la aceptación del "acervo comunitario" que implica el artículo 93 supone, tal y como señala este autor, no sólo las normas emanadas de los órganos comunitarios, sino también todas las declaraciones, resoluciones y acuerdos recogidos en los artículos 3 y 4 del Acta de Adhesión, firmada en Madrid el 12 de junio de 1985, ratificada por la Ley Orgánica de 2 de agosto del mismo año. 
No hay que olvidar que, al fin y al cabo, si el derecho de las organizaciones supranacionales puede prevalecer sobre la Constitución en ciertas materias, es porque así lo quiere la propia Constitución (art. 93). Por eso la reforma constitucional, en aplicación del artículo 95, lograría que, al menos formalmente, no se viera menoscabado el papel de la Constitución como norma suprema. Papel que, desde una perspectiva interna, quedaría asegurado por la posibilidad de control sucesivo respecto de los tratados, que aparece recogida en el artículo 27.2.c) de la Ley Orgánica del Tribunal Constitucional. Sin embargo, al formar el Estado español parte de la Comunidad, y dado que, desde la perspectiva comunitaria, los tratados comunitarios ocupan una posición supraconstitucional, parece que el artículo 95 está dirigido a evitar la utilización del control sucesivo respecto de los tratados.

De todas formas, puesto que todavía no se ha producido ningún pronunciamiento del Tribunal Constitucional con base en el procedimiento previsto en los artículos 95 de la Constitución y 78 de la LOTC, será necesario esperar a que la jurisprudencia constitucional delimite el alcance de este precepto en cada caso ${ }^{52}$.

52 Como ya señalábamos, es posible que en la práctica este precepto venga a cumplir la función de evitar que los tratados - también los comunitarios-sean objeto de control de constitucionalidad a posteriori.

En el momento de redactar estas líneas, el Tribunal Constitucional ha sido requerido por el Consejo de Ministros para que se pronuncie acerca de la existencia o no de contradicción en la Constitución y el Tratado de la Unión Europea firmado en Maastricht el pasado 7 de febrero. Sería, pues, el primer supuesto en que tendría aplicación práctica el artículo 95 del texto constitucional.

Se trata de que el Tribunal decida sobre la compatibilidad o incompatibilidad, con el artículo 8B de la segunda parte del Tratado, del artículo 13.2 de la Constitución, el cual excluye a los extranjeros del derecho de sufragio pasivo en elecciones municipales, mientras que el tratado recoge este derecho respecto de los ciudadanos comunitarios.

No pretendemos llegar a una conclusión sobre la necesidad o no de esta reforma. Son todavía poco numerosas las opiniones doctrinales que pueden encontrarse en relación con esta cuestión.

A. TORRES DEL MORAL (intervención en el Congreso La reforma constitucional en España, Logroño, 27-30 de abril de 1992) señala las cuatro posibilidades que existirian al respecto: la primera de ellas consistiría en no modificar nada, entendiendo que el texto del tratado tendría entrada, sin más, por la vía del artículo 93. En segundo lugar, cabría retocar la regulación de la nacionalidad y la extranjería a los efectos de considerar "nacionales» a los extranjeros residentes, para evitar así reformar el artículo 13 de la Constitución. Una tercera solución consistiría en reformar el artículo 13 mediante el procedimiento del artículo 167 de la Constitución. Una cuarta posibilidad alcanzaría también a la expresión "ciudadanos" del artículo 23 de la Constitución, para cuya reforma sería necesario acudir al procedimiento del artículo 168. 
En resumen, el Derecho comunitario, originario o derivado, anterior o posterior, prevalece sobre el Derecho estatal. Tal y como señala A. TORRES DEL MORAL, basándose en la jurisprudencia comunitaria, "en caso de colisión entre un Reglamento comunitario y el Derecho interno (es mejor decir Derecho de creación estatal, puesto que el Derecho comunitario también es interno) prevalece aquél, y el incumplimiento de una Directiva faculta a la Comisión de las Comunidades Europeas para emplazar al Estado español ante el Tribunal de Justicia en virtud del artículo 169 del Tratado de la CE. No empecen a esa obligación estatal de adaptar su ordenamiento jurídico al Derecho comunitario ni su estructura territorial, conforme a la cual dicha acomodación podría corresponder a una Comunidad Autónoma, ni las circunstancias constitucionales por las que atraviese, aunque sea la disolución de las Cámaras» ${ }^{53}$.

Por su parte, A. Mangas Martín, "La reforma constitucional en España: los tratados internacionales (artículos 93 a 96 de la CE) n, op. cit., en nota 5, en relación con este tema, califica la reforma constitucional como "innecesarian, en cuanto que podría encontrarse una interpretación de la Constitución que permitiera evitar la reforma. En este sentido, señala esta autora, es discutible que, desde 1986, los ciudadanos de otros Estados comunitarios deban considerarse, sin más, "extranjeros": el estatuto de los "españoles" debe considerarse extendido a los ciudadanos comunitarios; bastaría, por tanto, una reforma de la Ley electoral. Por otra parte, "el artículo 93 rige continuadamente nuestra vinculación a las Comunidades Europeas". "Por ello —continúa Mangas Martín-, una eventual contradicción entre un precepto constitucional y un precepto de los Tratados exige su confrontación con el artículo $93 \mathrm{CE}$ : si éste permite la atribución sin poner en peligro la pervivencia de la propia Constitución y del Estado mismo (es decir, de los elementos esenciales como son el Estado social y democrático de Derecho, el sistema autonómico, el nivel de protección de derechos y libertades). Ahí está el límite de lo que permite el artículo $93 \mathrm{CE}$. Luego, la Constitución española podrá aguantar las reformas periódicas de los Tratados comunitarios que se avecinan en esta década y en la siguiente hasta que la Unión Europea encuentre su horizonte final. Cuando éste llegue, quizás entonces tenga una oportunidad la reforma constitucional."

Puede verse, asimismo, respecto de esta cuestión, E. ARnaldo AlcubILla, "El derecho de sufragio de los extranjeros en las elecciones locales", Revista Española de Derecho Constitucional, n. ${ }^{\circ} 34$, enero-abril de 1992, págs. 67-97, concretamente págs. 92 y ss., donde se recogen las diversas posturas existentes sobre esta cuestión, y se afirma que la reforma constitucional será necesaria, salvo que el Tribunal constitucional declare la no existencia de contradicción.

53 A. ToRres del Moral, Estado de Derecho y Democracia de Partidos, op. cit., en nota 4, págs. 128-129. Las sentencias del TJCE citadas por este autor son las de 15 de julio de 1974 (Costa/ENEL), 17 de diciembre de 1970 (caso International Handelsgesellschaft), 9 de marzo de 1978 (caso Simmenthal), 23 de noviembre de 1982 (caso Centrale Raad van Beroep), 2 de febrero de 1982 y 11 de julio de 1984 (casos Comisión de las Comunidades Europeas contra Reino de Bélgica y contra República Italiana, respectivamente).

De todas formas, tal y como señala este autor, y como explicábamos en epígrafes anteriores, el principio que rige propiamente las relaciones entre el Derecho comunitario y el estatal es el de competencia. «El Derecho comunitario se aplica con 
En efecto, como ha señalado T. R. FERNÁNDEZ RODRÍGUEZ, la respuesta a la pregunta sobre qué lugar ocupan las fuentes comunitarias dentro de nuestro ordenamiento, dependerá en buena parte del tipo de fuente e, incluso, del tipo concreto de norma dentro de cada fuente (así, una directiva comunitaria, aunque dirigida a los Estados miembros, que deben transponerla a sus Derechos nacionales mediante una norma por ellos mismos emanada, puede producir en algunos casos efectos directos sobre los ciudadanos sin el intermedio de la norma estatal de transposición). Pero, haciendo abstracción, hay que afirmar que la relación del Derecho comunitario con el Derecho interno se rige por los principios ya estudiados, que implican la prioridad aplicativa del Derecho comunitario sobre cualquier otra norma nacional, que, en consecuencia, resulta desplazada por ella ${ }^{54}$.

La afirmación de la primacía del Derecho comunitario respecto del Derecho español conlleva la necesidad de referirnos brevemente, en los apartados siguientes, a algunas de sus consecuencias.

\section{b) La ley nacional posterior y la constitucionalidad del Derecho comunitario}

La colisión de una norma comunitaria con una norma nacional posterior con rango de ley ha planteado problemas en otros Estados miembros, como ya hemos tenido oportunidad de ver en el epígrafe anterior.

Para abordar este tema en relación con el Derecho español, puede servirnos como punto de partida el artículo 117.1 de la Constitución, donde se señala que los jueces y magistrados que integran el Poder Judicial están "sometidos únicamente al imperio de la ley".

Ésta es la razón por la que, al contrario de lo que sucede con las normas de rango inferior al legal, los jueces no pueden inaplicar por sí

preferencia porque el Estado le ha cedido a la Comunidad la regulación de determinadas materias; por tanto, dicha aplicación preferente se circunscribe a esas materias tasadas y no permite una expansión no consentida de las competencias comunitarias a costa de las estatales") (A. TORRES deL Moral, ibidem, pág. 129). Por eso, primacía no equivale en todo caso a supremacía (véase también A. TORRES DEL MoRAL, Principios de Derecho constitucional español, Madrid, Ediciones Átomo, 2. edición, 1988, vol I; asimismo, 3. ${ }^{a}$ ed., Publicaciones de la Facultad de Derecho, Universidad Complutense, 1992).

54 T. R. Fernández Rodríguez, en E. García de Enterría y T. R. Fernández, Curso de Derecho Administrativo, op. cit., en nota 46, págs. 177 y ss. 
mismos las leyes, sino que, en caso de duda, deben someter la cuestión ante el Tribunal Constitucional (arts. 163 de la Constitución y 35 LOTC).

Cabe preguntarse, entonces, si un juez, a la hora de aplicar una ley nacional posterior y contraria a una norma comunitaria, puede o no apartarse de aquélla, planteando la cuestión al Tribunal Constitucional.

Ante este problema, no cabe sino partir del principio de primacia del Derecho comunitario, elaborado, como ya sabemos, por la jurisprudencia del Tribunal de Justicia de la Comunidad.

Si el Derecho comunitario goza de primacía, podría pensarse que el juez nacional podría plantear una cuestión de inconstitucionalidad respecto de la norma nacional posterior basándose en la posible infracción del principio de jerarquía normativa, recogido en el artículo 9.3 del texto constitucional.

Sin embargo, la doctrina del Tribunal de Justicia sobre la primacía del Derecho comunitario, como ya hemos visto, no deja lugar a dudas. Si el juez nacional plantea la cuestión, tendrá que esperar, para inaplicar la ley, al fallo del Tribunal Constitucional, y entre tanto se está relegando la eficacia de la norma comunitaria, por lo que parece que no cabría el planteamiento de la cuestión de inconstitucionalidad.

Además, otros preceptos de la Constitución y de la Ley Orgánica del Poder Judicial vienen a apoyar esta solución. Así, si es cierto que el juez ordinario está sometido al imperio de la ley, también lo es que está vinculado por la Constitución (art. 5.1 LOPJ), y por tanto, también por los artículos 93 y 96 de nuestra Norma Fundamental.

Sin olvidar que el artículo 9.1 de la Constitución determina su sometimiento a la Constitución "y al resto del ordenamiento jurídico". Si el Derecho comunitario es derecho aplicable, forma parte de ese "ordenamiento jurídicon. Y si es jerárquicamente superior, el juez deberá aplicarlo, desplazando cualquier norma interna.

Siendo así las cosas, faltaría incluso alguno de los requisitos previstos por el artículo 163 de la Constitución para plantear la cuestión de inconstitucionalidad, ya que la «norma aplicable al caso" sería no la nacional, sino la comunitaria.

Cabe, entonces, preguntarse qué hacer con esa ley nacional posterior y contraria a la norma comunitaria. La primacía del Derecho comunitario quedaría salvada con la mera inaplicación de esa ley nacional posterior. Pero se puede ir más lejos, planteándose la posibilidad de adaptar 
esa ley nacional a la norma comunitaria, o bien, simplemente, de derogarla. En efecto, parece incoherente mantener en vigor una norma inaplicable, opuesta a otra que goza de primacía respecto de ella, y la mera inaplicación sería contraria a la seguridad jurídica. La consolidación de la primacía, y el cumplimiento del artículo 5 TCEE, no permiten que la primacía se vaya logrando en casos concretos a base de sentencias judiciales que inapliquen la norma nacional contraria. Por otra parte, la derogación no parece la solución más correcta, puesto que esa ley puede ser aplicada respecto de Estados no miembros. Parece que el camino más coherente con los objetivos comunitarios y con el propio artículo 5 TCEE es la adaptación de la norma nacional a la comunitaria ${ }^{55}$.

No se olvide, además, que el cumplimiento de las obligaciones comunitarias puede venir exigido frente a los demás Estados y frente a la Comunidad en los términos del artículo 169 TCEE.

Sirven estas consideraciones para enlazar con la siguiente cuestión que cabe plantearse. Y ésta es la de si cabe el planteamiento de algún proceso constitucional respecto de la norma comunitaria que se oponga a la Constitución. Nos referimos en este caso a las normas de Derecho derivado, puesto que a las normas de Derecho originario (nuevos tratados firmados en el seno de la Comunidad o modificaciones de los existentes) sería de aplicación, en su caso, el artículo 95, en los términos que hemos expuesto en el apartado anterior.

El panorama doctrinal ofrece soluciones diversas. Así, A. MANGAS MARTíN entiende que el Derecho comunitario no puede ser objeto de control de constitucionalidad por parte del Tribunal Constitucional, puesto que las normas comunitarias han sido emanadas dentro de un sistema jurídico distinto al de los ordenamientos estatales, y además las Comunidades cuentan con un Tribunal propio, encargado de garantizar la aplicación y respeto del Derecho comunitario en la interpretación y aplicación de los tratados. La validez de las normas derivadas comunitarias no debe confrontarse, por tanto, con la Constitución de los Estados miembros, sino con los Tratados comunitarios, y por eso el Tribunal competente es el comunitario. Además, el recurso prejudicial regulado en el artículo 177 TCEE establece una vía directa de contacto entre el juez nacional y el Tribunal comunitario, para resolver las dudas de validez $e$

55 De estas cuestiones se ocupó, en el período inmediatamente anterior a la aplicabilidad en España del Derecho comunitario, P. PÉREZ TrEMPS, «Justicia comunitaria, Justicia constitucional y Tribunales ordinarios frente al Derecho comunitario (Comentario a la Sentencia de la Corte Constitucional italiana número 170/1984, de 8 de junio)", op. cit., en nota 30 , págs. 174 y ss. 
interpretación en relación con la aplicación del Derecho comunitario. Por su parte, los particulares españoles y el propio Estado español pueden utilizar los artículos 173 y 184 TCEE para impugnar la legalidad de los actos comunitarios. Por tanto, debe excluirse la posibilidad de admisión de recursos o cuestiones de inconstitucionalidad respecto de las normas comunitarias ${ }^{56}$.

Otros autores, si bien parten de la misma opinión, no renuncian a una cierta competencia del Tribunal Constitucional en casos límites, es decir, cuando se trate de supuestos "en los que está en juego la pervivencia de la propia Constitución (...), ya que en ningún caso parece posible que la transferencia de competencias que autoriza el artículo 93 pueda concluir en una transmisión de poder en cuyo ejercicio puedan luego abatirse incluso los componentes esenciales del texto fundamental que permitió aquella transferencia ${ }^{57}$.

Por su parte, A. REMIRO BROTONS mantiene una posición más favorable a la competencia del Tribunal Constitucional, afirmando que el artículo 93 «no sirve para configurar al Derecho comunitario como un ámbito exento al control de la constitucionalidad encomendado al Tribunal Constitucional». Como posible solución, propone este autor que el Tribunal Constitucional, ante cuestiones de inconstitucionalidad planteadas por jueces nacionales, pueda hacer uso del recurso prejudicial del artículo 177 TCEE, utilizando luego el fallo del Tribunal comunitario como premisa para su razonamiento ${ }^{58}$.

Por nuestra parte, aunque la segunda y la tercera de las posiciones doctrinales enunciadas no son totalmente desechables (especialmente si

56 A. MANgas Martín, Derecho comunitario europeo y Derecho español, 2." edición, Madrid, 1987, págs. 144 y ss.

57 S. Muñoz Machado, El Estado, el Derecho interno y la Comunidad Europea, op. cit., en nota 16, págs. 264 y ss.

68 A. Remiro Brotons, Derecho internacional público. Vol. II: Derecho de los tratados, Madrid, 1987, págs. 344 y ss.

Por su parte, L. I. SÁnCHez Rodriguez, "El artículo 93 CE y el bloque de constitucionalidad: algunos problemas", en Estudios sobre la Constitución española. Homenaje al profesor Eduardo García de Enterría, Madrid, Civitas, 1991, tomo l, págs: 219-250, tras recoger las posiciones doctrinales que acabamos de resumir, se pronuncia (pág. 249) en el sentido de que "ha de admitirse que el examen del conflicto entre normas constitucionales y normas comunitarias de Derecho derivado supone, en cuanto actitud teórica, tener en cuenta hipótesis excepcionales, muy extremas y nada cotidianas; pero no imposibles». Parece reconocer, por tanto, cierta competencia al Tribunal, que deberá tener en cuenta el artículo 93, interpretado sistemáticamente junto con el resto del texto constitucional. 
tenemos en cuenta la posible existencia de casos límite), consideramos la primera de ellas la más correcta en pura argumentación jurídica. El Derecho comunitario es un sistema jurídico autónomo, y las normas de Derecho derivado deben ajustarse a los Tratados constitutivos, y no a la Constitución. Por tanto, el Tribunal competente será el TJCE, y no el Tribunal Constitucional.

Por eso, la norma comunitaria deberá ser atacada en sede comunitaria, y no mediante los procesos de constitucionalidad previstos por nuestro ordenamiento constitucional. Las vías para la impugnación de las normas comunitarias serán las ya aludidas, y recogidas por los artículos 173 y 184 TCEE, así como el recurso prejudicial del artículo 177. Esta última vía ha sido utilizada con escasa frecuencia desde nuestra incorporación a las Comunidades: sólo seis cuestiones prejudiciales entre enero de 1986 y diciembre de $1990^{59}$.

Respecto del tema que nos ocupa, el Tribunal Constitucional ha tenido algunas oportunidades de pronunciarse. Lo que ha hecho el Tribunal Constitucional ha sido considerar que no es él quien tiene que pronunciarse a la hora de definir la compatibilidad entre el Derecho español y el comunitario, y no ha planteado la cuestión prejudicial ante el Tribunal comunitario, a pesar de que el planteamiento de la cuestión prejudicial es obligatorio, según el artículo 177.3 TCEE, «cuando se plantee una cuestión de este tipo en un asunto pendiente ante un órgano jurisdiccional nacional cuyas decisiones no sean susceptibles de ulterior recurso judicial de Derecho interno".

59 Como ya indicábamos, el Tribunal Supremo viene aceptando la primacía del Derecho comunitario. Sólo en sentencia de 21 de diciembre de 1988 habla de "armonización legislativa", considerando Derecho comunitario y Derecho interno en un plano de igualdad. En otras sentencias ( 28 de abril de 1987, 27 de abril de 1989), el Tribunal Supremo se ha mostrado respetuoso con la primacia.

La primera cuestión prejudicial planteada ante el TJCE lo fue por el Tribunal Central de Trabajo (Sala 4.") mediante auto de 21 de marzo de 1986. EI TJCE resolvió el asunto en sentencia de 29 de septiembre de 1987.

Otras cuestiones prejudiciales han sido las planteadas por la Sala 2. $\mathrm{a}$ de lo Contencioso-Administrativo de la Audiencia Territorial de Valencia, mediante auto de 15 de junio de 1988, resuelta por sentencia del TJCE de 11 de julio de 1989; la planteada por el Juzgado de Primera Instancia n. 1 de Oviedo mediante auto de 13 de marzo de 1989, resuelta por sentencia del TJCE de 13 de noviembre de 1990, y la planteada por la Sección 2.ạ de la Sala de lo Contencioso-Administrativo del Tribunal Superior de Cataluña (auto de 7 de noviembre de 1989), resuelta por sentencia del TJCE de 25 de julio de 1991. 
En efecto, el Tribunal Constitucional aborda estas cuestiones en sus sentencias 28/1991, de 14 de febrero, $y$ 64/1991, de 22 de marzo ${ }^{60}$.

Según la primera de estas decisiones, en la que se cita la sentencia Costa/ENEL para reconocer la integración del Derecho comunitario en el ordenamiento interno, señala que ello

"...no significa que por mor del artículo 93 se haya dotado a las normas del Derecho comunitario europeo de rango y fuerza constitucionales, ni quiere en modo alguno decir que la eventual infracción de aquellas normas por la disposición española entrañe necesariamente a la vez una conculcación del citado artículo 93 de la Constitución".

Así, las posibles contradicciones no plantean problemas de inconstitucionalidad que deban ser resueltos por el Tribunal Constitucional, sino que su resolución corresponde a los órganos jurisdiccionales ordinarios, facultados u obligados, según los casos, para plantear el recurso prejudicial del artículo 177 TCEE.

En la segunda de las sentencias citadas, el Tribunal vuelve a señalar que

«...no corresponde al Tribunal Constitucional controlar.la adecuación de la actividad de los poderes públicos nacionales al Derecho comunitario europeo. Este control compete a los órganos de la jurisdicción ordinaria, en cuanto aplicadores que son del ordenamiento comunitario, $y$, en su caso, al Tribunal de Justicia de las Comunidades Europeas a través del recurso por incumplimiento (art. 170 TCEE). La tarea de garantizar la recta aplicación del Derecho comunitario europeo por los poderes pú-

60 La sentencia 28/1991, de 14 de febrero, resuelve un recurso de inconstitucionalidad presentado contra los artículos 211.2.d) y 214, que la Ley Orgánica 1/1987, de 2 de abril, introdujo en la Ley Orgánica 5/1985, de 19 de junio, del Régimen electoral general, acerca de la regulación de las elecciones al Parlamento Europeo. El Tribunal desestimó el recurso. La doctrina que especialmente nos interesa está expuesta en los fundamentos jurídicos 4 y 6 .

La sentencia 64/1991, de 22 de marzo, resuelve varios recursos de amparo acumulados contra Resoluciones de la Secretaría General de Pesca. En su fundamento juridico $4 .^{\circ}$ aborda el tema de la cesión de competencias constitucionales a organizaciones internacionales en relación con el Derecho comunitario europeo, $y$ a propósito del acceso a los caladeros de pesca. Estas sentencias han sido comentadas por A. SÁNCHEZ LEGIDO, "Las relaciones entre el Derecho comunitario y el Derecho interno en la jurisprudencia del Tribunal Constitucional», Revista Española de Derecho Constitucional, n. 33, septiembre-diciembre de 1991, págs. 175-207. Véase también, en relación con estas cuestiones, el trabajo de J. R. FERNÁNDEZ, "El control del Derecho interno que infrinja el Derecho comunitario europeo $y$ el alcance del artículo $10.2 \mathrm{CE}$ en la jurisprudencia del Tribunal Constitucional", Revista Española de Derecho Administrativo, n.ำ 2 , octubre-diciembre de 1991. 
blicos nacionales es, pues, una cuestión de carácter infraconstitucional y, por lo mismo, excluida tanto del ámbito del proceso de amparo como de los demás procesos constitucionales».

\section{c) Derecho comunitario y derechos fundamentales}

Se plantea, también desde la perspectiva de nuestro ordenamiento, la posibilidad de que una norma comunitaria vulnere principios materiales de la Constitución, en aspectos esenciales del orden constitucional, como el que constituye el elenco de derechos fundamentales reconocidos por nuestro texto constitucional.

La solución aquí viene dada de nuevo por la jurisprudencia comunitaria que hemos estudiado en el epígrafe anterior. Es claro que nuestro Tribunal Constitucional no es competente para decidir sobre la adecuación o no a la Constitución de las disposiciones comunitarias, tal y como acabamos de ver.

Puesto que, como ya sabemos, el Tribunal de Justicia comunitario ha señalado que los derechos fundamentales son parámetro de validez de los actos comunitarios, los tribunales internos habrán de utilizar el recurso prejudicial para que sea el TJCE quien decida sobre la aplicación del Derecho comunitario.

A lo ya dicho sobre la posibilidad de plantear cuestiones de inconstitucionalidad, hay que añadir, con PÉREZ TREMPS, que la solución para estos casos de derechos fundamentales no podría consistir - de ser ésta posible - en una cuestión de inconstitucionalidad contra la ley de adhesión al tratado, pues la posible vulneración vendría de la norma comunitaria, no de la ley de adhesión. En definitiva, aceptar las estructuras comunitarias supone también aceptar la prevalencia de la interpretación del Tribunal de Justicia respecto de las normas comunitarias ${ }^{61-61}$ bis.

Nuestro Tribunal Constitucional también se ha pronunciado sobre esta materia, con la misma argumentación que ya conocemos. En efecto, en la citada sentencia 64/1991 ha señalado que

61 P. Pérez Tremps, "Justicia comunitaria, Justicia constitucional y Tribunales ordinarios frente al Derecho comunitario (Comentario a la Sentencia de la Corte Constitucional italiana número 170/1984, de 8 de junio/», op. cit., en nota 30, pág. 179.

En relación con esta temática, véase también M. MONTORO Puerto, Jurisdicción constitucional y procesos constitucionales. Tomo II: Procesos de protección de los derechos fundamentales, Madrid, Colex, 1991, págs. 411 y ss., especialmente 
«...la vinculación al Derecho comunitario -instrumentada, con fundamento en el artículo 93 de la Constitución en el Tratado de Adhesión-y su primacía sobre el Derecho nacional en las referidas materias no pueden relativizar o alterar las previsiones de los artículos 53.2 y 161.1.b) de la Constitución. Es por ello evidente que no cabe formular recurso de amparo frente a normas o actos de las instituciones de la Comunidad, sino sólo, de acuerdo con lo dispuesto en el artículo 41.2 de la LOTC, contra disposiciones, actos jurídicos o simple vía de hecho de los poderes públicos internos. $Y$ es asimismo patente que los motivos de amparo han de consistir siempre en lesiones de los derechos fundamentales y libertades públicas enunciados en los artículos 14 a 30 de la Constitución (...), con exclusión, por tanto, de las eventuales vulneraciones del Derecho comunitario, cuyas normas, además de contar con específicos medios de tutela, únicamente podrían llegar a tener, en su caso, el valor interpretativo que a los tratados internacionales asigna el artículo 10.2 de la Constitución".

Así, el Tribunal Constitucional, aceptando la primacía del Derecho comunitario, declara que sólo es competente para conocer de vulneraciones de derechos fundamentales procedentes de poderes públicos internos, y sólo si se entiende vulnerado alguno de los derechos fundàmentales recogidos en la Constitución.

Ahora bien, esa aceptación de la primacía como principio por nuestro Tribunal Constitucional no está exenta de peculiaridades, puesto que no se renuncia a la propia identidad y aplicabilidad de los derechos fundamentales recogidos en nuestro texto constitucional:

págs. 442-444. En torno a la ausencia de un catálogo de derechos en los tratados fundacionales, y la problemática que desde el punto de vista constitucional plantea esta carencia, véase L. M. DiEz-PICAZO, "¿Una Constitución sin declaración de derechos? (Reflexiones constitucionales sobre los derechos fundamentales en la Comunidad Europea)", Revista Española de Derecho Constitucional, n.. 32, mayo-agosto de 1991, págs. 135-155.

61 bis (1994) Respecto de esta cuestión, hay que señalar que el principal obstáculo para determinar la forma jurídica de la Unión Europea, así como para su calificación como estructura de carácter federal es, precisamente, la ausencia de un aúténtico "Texto constitucional» de la Comunidad. En este sentido hay que hablar de la existencia de un Proyecto de Constitución Europea, elaborado por la Comisión de Asuntos Constitucionales del Parlamento Europeo, cuyo ponente fue el eurodiputado español Marcelino Oreja Aguirre. La última versión de este proyecto tiene fecha de 27 de abril de 1993. Con posterioridad a esta fecha, el ponente dejó de ser miembro del Parlamento Europeo, debido a su elección como parlamentario español. El proyecto quedó sin pasar de tal. Se trata simplemente de un documento de trabajo, no aprobado de forma definitiva por ninguna institución comunitaria. Sobre este proyecto y la regulación de los derechos humanos, principios generales $y$ otros diversos aspectos, véase el "Análisis del Proyecto de Constitución Europea" presentàdo por el profesor F. DE CARreras SerRa como ponencia en el XIII Congreso de la Asociación Española de Teoría del Estado y Derecho Constitucional (Madrid, noviembre 1993), cuyas actas se publicarán próximamente en el $n .^{\circ} 17$, monográfico de la $R e$ vista de la Facultad de Derecho de la Universidad Complutense. Este Congreso estuvo dedicado a los "Problemas político-constitucionales de la Unificación europea». 
«...La única medida de enjuiciamiento aplicable (...) es la integrada por los preceptos de la Constitución que reconocen aquellos derechos fundamentales y libertades públicas, cuyo contenido y alcance, no obstante, habrá de interpretarse de conformidad con los tratados y acuerdos internacionales a que hace referencia el artículo 10.2 de la Constitución.

La interpretación a que alude el citado artículo 10.2 del texto constitucional no convierte a tales tratados y acuerdos internacionales en canon autónomo de validez de las normas $y$ actos de los poderes públicos desde la perspectiva de los derechos fundamentales. Si así fuera, sobraría la proclamación constitucional de tales derechos, bastando con que el constituyente hubiera efectuado una remisión a las Declaraciones internacionales de Derechos Humanos..."

Además, el Tribunal Constitucional se considera competente cuando la posible vulneración de derechos por parte del poder público interno se produzca en ejecución del Derecho comunitario:

"En conclusión, pues, es claro también que, en la medida en que se impugne en amparo un acto del poder público que, habiendo sido dictado en ejecución del Derecho comunitario europeo, pudiera lesionar un derecho fundamental, el conocimiento de tal pretensión corresponde a esta jurisdicción constitucional..."

Por otra parte, como ya hemos visto, la postura del Tribunal Constitucional es contraria a plantear la cuestión prejudicial ante el TJCE, por entender que esa misión corresponde a los Tribunales ordinarios, ya que éstos y el propio TJCE son los aplicadores del Derecho comunitario. (STC 64/1991, FJ 4. 9 . Postura que, si bien es correcta desde un punto de vista lógico y técnico, podría llegar a dar lugar a algún supuesto de indefensión.

Lo que, en definitiva, no se pone en entredicho es que la integración en la Comunidad supone la incorporación del Derecho comunitario a nuestro ordenamiento. Esta integración implica una cesión de soberanía, que no debe llevar a la renuncia a las estructuras y pilares básicos del Estado de derecho, entre los que se encuentra la protección de los derechos fundamentales de los ciudadanos. En cualquier caso, la actitud positiva del Tribunal de Justicia comunitario en esta materia viene a disipar en buena medida el temor de que puedan llegar a producirse situaciones intolerables para un Estado democrático de Derecho.

\section{d) Derecho comunitario y Comunidades Autónomas}

La descentralización política operada en España en virtud de los artículos 2 y 137 de la Constitución ha dado pie para la formación y funcionamiento de Comunidades Autónomas dotadas de potestades legislativas. Ello hace que la problemática de las fuentes del Derecho en relación con el Derecho comunitario haya de analizarse también en relación con esa facultad normativa de las Comunidades Autónomas. 
En efecto, la transferencia de "competencias derivadas de la Constitución", prevista en el artículo 93 de nuestra Norma Fundamental, parece que incluye también la de las competencias autonómicas, ya que el fundamento de éstas se encuentra también en la Constitución.

En suma, la incorporación de España a la Comunidad Europea ha supuesto la cesión a esta instancia supranacional no sólo de competencias que antes fueran ejercidas por el poder central, sino también de competencias autonómicas.

Teniendo en cuenta, además, que la relación entre el Derecho estatal y el autonómico obedece, más que al principio de jerarquía, al de competencia, puede concluirse de todo ello que la adhesión a la Comunidad Europea ha traído como consecuencia, en las competencias transferidas a la organización supranacional, una pérdida de poder, tanto para el Estado central como para las Comunidades Autónomas.

En definitiva, nos encontramos ante un problema que la Constitución no resuelve: la confluencia de tres órdenes normativos: el comunitario, el estatal y el autonómico ${ }^{62}$.

Problema que se acentúa si se tiene en cuenta que es difícil y poco recomendable la extrapolación de las categorías normativas comunitarias al ámbito nacional.

Lo que sí puede afirmarse con carácter general es que las competencias que antes eran exclusivas del Estado han pasado a ser compartidas, en lo que abarque el ámbito competencial comunitario, con las Comunidades Europeas. Y si la competencia era compartida entre el Estado y las Comunidades Autónomas, ha pasado a ser compartida también con la organización supranacional en lo que entre dentro de las atribuciones de ésta.

El problema, además, se plantea por el hecho de que, si bien el ejer-. cicio de las competencias -esencialmente normativas- ha sido transferido a las instancias comunitarias, la aplicación de las normas adoptadạs

62 En esta materia seguimos fundamentalmente los trabajos de $\mathrm{S}$. MuÑoz MaChado, El Estado, el Derecho interno y la Comunidad Europea, op. cit., en nota 16, y J. JUSTE RUIz, "La aplicación del Derecho comunitario europeo y la Constitución española de 1978 ", op. cit., en nota 50, págs. 287 y ss. A estas cuestiones se ha referido también E. Garcia de EnTERRía, "La participación de las Comunidades Autónomas en la formación de las decisiones comunitarias", Revista Española de Derecho Constitucional, n. 933 , septiembre-diciembre de 1991, págs. 3-27. Pone de relieve este autor (págs. 4 y ss.) que el constituyente español ejercitó a la vez dos opciones: la autonómica - art. 2 de la Constitución-y la supranacional (concretamente europea), en el artículo 93. García de Enterría afirma en este trabajo que ambas opciones son compatibles e incluso complementarias. 
por esas instituciones debe realizarse principalmente en sede nacional. Por ello se plantea la disyuntiva entre la utilización del marco estatal, o bien de los autonómicos, para el cumplimiento de esas normas ${ }^{63}$.

Hay que tener en cuenta, además, que el artículo 149.1.3. ${ }^{\mathrm{a}}$ supone un obstáculo para la participación de las Comunidades Autónomas en las decisiones comunitarias, ya que, según este precepto, el Estado tiene competencia exclusiva sobre «relaciones internacionales». Sin embargo, como señala MUÑOZ MACHADO, este riesgo de pérdida de poder de decisión se ve contrarrestado por la tesis de la competencia implícita de ejecución de las Comunidades Autónomas en las materias que les correspondan según sus estatutos. Ello sin perjuicio de que el Estado asuma esa función de ejecución en los demás casos, pudiendo siempre, además, ejercer los poderes de supervisión, uniformación o sustitución que, para hacer efectiva la responsabilidad, contempla el artículo 93 de la Constitución ${ }^{64}$.

No hay que olvidar, por otra parte, que este último inciso del artículo 93 de la Constitución podría ser interpretado en el sentido de reservar a los órganos centrales la aplicación del Derecho comunitario.

No parece que deba interpretarse así este precepto, según el cual "corresponde a las Cortes Generales o al Gobierno, según los casos, la garantía del cumplimiento de estos tratados y de las resoluciones emanadas de los organismos internacionales o supranacionales titulares de la cesión".

En realidad, una interpretación conjunta de los artículos 149.1.3. ${ }^{\mathrm{a}} \mathrm{y}$ 93 parece que debe conducir a la conclusión de que lo que se produce es una pérdida de competencias, centrales y autonómicas, pero ello no quiere decir que se genere un título específico en virtud del cual la aplicación o desarrollo normativo del Derecho comunitario corresponda sólo a las autoridades centrales. En efecto, la competencia exclusiva en relaciones internacionales se refiere a la acción exterior, y no a la aplicación en el interior de la normativa, en este caso, comunitaria. En este sentido hay que añadir, por otra parte, que la distribución de competencias entre Estado y Comunidades Autónomas sigue vigente ${ }^{65-65 \text { bis. }}$.

63 J. Juste Rurz, ibidem, pág. 288.

El problema se plantea, en particular, como puede verse, en relación con las potestades normativas. No así en relación con las jurisdiccionales, ya que el poder judicial es único en virtud de lo establecido por el artículo 117.5 de la Constitución.

64 S. MuÑoz MACHAdo, El Estado, el Derecho interno y la Comunidad Europea, op. cit., en nota 16, pág. 126.

${ }_{65}$ J. JuSTE RUIz, "La aplicación del Derecho comunitario europeo y la Constitución española de 1978», op. cit., en nota 50, pág. 289.

65 bis (1994) En relación con este y otros aspectos de la problemática abordada en este apartado, véase mi trabajo "Comunidades autónomas y Derecho Co- 
Lo que sí existe, y parece que en relación con ello hay que interpretar la "garantía de cumplimiento" de que habla el artículo 93, es un control estatal de la aplicación del Derecho comunitario por las Comunidades Autónomas. Precepto que, junto con las diversas disposiciones constitucionales que regulan diversos aspectos de las relaciones entre el Estado y las Comunidades Autónomas, vendrían a configurar el sistema de garantías para la ejecución del Derecho comunitario por parte de las Comunidades Autónomas.

En este sentido, J. JUSTE RUIZ distingue una triple garantía gubernamental, junto con las garantías legislativa y judicial. Conjunto de garantías que, sin embargo, no logra evitar la posible existencia de lagunas y aspectos problemáticos, y conlleva no pocos problemas jurídicos y políticos ${ }^{66}$.

Así, la garantía gubernamental se ejerce, en primer lugar, en vía administrativa, mediante el dictamen preceptivo del Consejo de Estado, de acuerdo con lo previsto en los artículos 21.2, 22.2 y 263 de su Ley Orgánica (Ley Orgánica 3/1980, de 22 de abril) ${ }^{67}$.

munitario Europeo", presentado como Comunicación al XIII Congreso de la Asociación Española de Teoría del Estado y Derecho Constitucional, de próxima aparición, en el $n .^{\circ} 17$, monográfico, de la Revista de la Facultad de Derecho de la Universidad Complutense de Madrid. Contiene este trabajo referencias a la doctrina y jurisprudencia en relación con la cuestión del reparto de competencias. A la vista de las SSTC en la materia, principalmente las 252/1988, de 20 de diciembre; 76/1991, de 11 de abril; 117/1992, de 16 de septiembre, etc., la doctrina del Tribunal Constitucional puede resumirse en la idea de que el reparto de competencias entre Estado y Comunidades Autónomas es una cuestión de Derecho interno, de tal modo que la determinación del ente competente para la ejecución del Derecho comunitario - sea en sede legislativa o administrativa - vendrá dada por la normativa interna que regula el reparto de competencias (principio de autonomía institucional). Normativa que, como es sabido, presenta a su vez una amplia problemática en la que aquí no es posible detenerse. Véase, además, P. Pérez Tremps, Comunidades Autónomas, Estado y Comunidad Europea, Madrid, Ministerio de Justicia, 1987.

${ }_{66}^{6}$ J. Juste RuIz, ibidem, págs. 294-297.

67 En virtud de estos preceptos, el Consejo de Estado en pleno deberá ser consultado sobre "anteproyectos de leyes que hayan de dictarse en ejecución, cumplimiento o desarrollo de tratados, convenios o acuerdos internacionales" (art. 21.2). Asimismo, su Comisión Permanente deberá ser consultada en materia de "disposiciones reglamentarias que se dicten en ejecución, cumplimiento y desarroIlo de tratados, convenios o acuerdos internacionales" (art. 22.2). Por último, según el artículo 23, "las Comunidades Autónomas podrán, por conducto de sus Presidentes, solicitar dictamen del Consejo de Estado, bien en Pleno o en Comisión Permanente, en aquellos asuntos en que, por la especial competencia o experiencia del mismo, lo estimen conveniente». Y en su párrafo segundo: «El dictamen será preceptivo para las Comunidades en los mismos casos previstos en esta Ley para el Estado, cuando hayan asumido las competencias correspondientes". 
En segundo lugar, el Gobierno puede impugnar las disposiciones y resoluciones de las Comunidades Autónomas, por la vía general del conflicto de competencias previsto en el artículo 161.1.c) de la Constitución y 59 y ss. LOTC, o bien por la vía del artículo 161.2 de la Constitución, con suspensión, en este último caso, de la vigencia de la norma impugnada.

Cabe, en tercer lugar, el control consistente en medidas de cumplimiento forzoso, previsto en el art. 155 de la Constitución, si bien este procedimiento, por su contundencia, es menos aconsejable que los anteriores ${ }^{68}$.

Por otra parte, desde 1985 se han elaborado algunos proyectos de convenio entre el Estado y las Comunidades Autónomas acerca de la ejecución del Derecho comunitario, aplicación que se considera como "obligación superior y prevalente", que debe cumplirse en función de la ordenación constitucional de competencias ${ }^{69}$.

La garantía legislativa consiste, aparte del control parlamentario, en la adopción por las Cortes Generales de medidas legislativas para asegurar la correcta aplicación del Derecho comunitario por las Comunidades Autónomas.

Esas medidas legislativas podrán dictarse, por ejemplo, para cubrir lagunas normativas autonómicas, con apoyo en la cláusula del artículo 149.3 de la Constitución, según la cual "el derecho estatal será, en todo caso, supletorio del Derecho de las Comunidades Autónomas".

Además, es posible la adopción de leyes de armonización conforme a lo dispuesto en el artículo 150.3 de la Constitución, "para armonizar las disposiciones normativas de las Comunidades Autónomas, aun en el caso de materias atribuidas a la competencia de éstas, cuando así lo exija el interés generalm.

68 Según el artículo 155 de la Constitución, "si una Comunidad Autónoma no cumpliere las obligaciones que la Constitución $u$ otras leyes le impongan, 0 actuare de forma que atente gravemente al interés general de España, el Gobierno, previo requerimiento al Presidente de la Comunidad Autónoma, y en el caso de no ser atendido, con la aprobación por mayoría absoluta del Senado, podrá adoptar las medidas necesarias para obligar a aquélla al cumplimiento forzoso de dichas obligaciones o para la protección del mencionado interés general". En el párrafo segundo se establece que upara la ejecución de las medidas previstas en el apartado anterior, el Gobierno podrá dar instrucciones a todas las autoridades de las Comunidades Autónomas".

69 Proyecto de convenio entre el Gobierno de la Nación y las Comunidades Autónomas sobre cooperación en los asuntos relacionados con las Comunidades Europeas, de diciembre de 1985. La Generalidad de Cataluña presentó un texto alternativo. En abril de 1986 se elaboró un nuevo texto del proyecto de convenio. Vid. I. JUSTE RUIz, "La aplicación del Derecho comunitario europeo y la Constitución española de 1978", op. cit., en nota 50, pág. 295. 
Ninguna de estas dos posibilidades, sin embargo, representan garantías específicas para la aplicación del Derecho comunitario ${ }^{70}$.

En cuanto a la garantía judicial, cabe referirse al papel que en la aplicación del Derecho comunitario por las Comunidades Autónomas desempeñan tanto el Tribunal Constitucional como los Tribunales contencioso-administrativos.

El primero actuará al resolver posibles recursos de inconstitucionalidad (si las disposiciones autonómicas tienen rango de ley) o conflictos de competencias, proceso éste más frecuente (a iniciativa, en la mayoría de los casos, de las propias Comunidades Autónomas), y que parece más adecuado para este cometido.

Los Tribunales contencioso-administrativos también pueden desempeñar una labor, aunque limitada, en la garantía del cumplimiento del Derecho comunitario "1.

Una vez enumeradas sucintamente estas garantías, no cabe sino recordar la importancia que tiene, desde el punto de vista de las relaciones de España en el seno de la Comunidad, el cumplimiento de sus obligaciones para con la misma, cumplimiento que pasa por una correcta aplicación del Derecho comunitario, también por las Comunidades Autónomas. En este sentido, el Tribunal de Justicia de las Comunidades mantiene el criterio de la responsabilidad exclusiva del Estado, recordando que

"...ante las Comunidades Europeas, el Estado miembro y sólo el Estado miembro, es decir, el Gobierno central, es responsable del cumplimiento íntegro, y dentro de los plazos previstos por la normativa comunitaria, de la legalidad comunitaria. No cabe invocar argumentos de índole

70 I. Juste Ruiz, ibidem, págs. 295-296.

1 G. Garzón Clariana ( «La ejecución del Derecho comunitario en España y las competencias de las Comunidades Autónomas», en La aplicación del Derecho de la Comunidad Europea por los órganos sub-estatales, Generalitat de Catalunya, Institut d'Estudis Autonomics, 1986, págs. 204 yss, en concreto pág. 237) señala que las principales carencias de este mecanismo se observan a partir de las siguientes consideraciones: a) el recurso contencioso-administrativo se restringe a la esfera de las disposiciones autonómicas de carácter administrativo; b) su utilización es más eficaz en los supuestos de disposiciones incompatibles con el Derecho comunitario que en los de ausencia de medidas autonómicas de ejecución; c) la interposición de este recurso no supone necesariamente la suspensión cautelar de las disposiciones impugnadas; d) su eficacia real como instrumento de garantía de la correcta aplicación del Derecho comunitario depende en gran medida del oportuno planteamiento de la cuestión prejudicial ante la Comunidad Europea (citado por J. JuSTE RuIz, ibidem, pág. 297). 
constitucional interna dẹl Estado miembro ni alegar como excusa de incumplimiento un determinado modo de estructura de ese Estado" ${ }^{72-72 \text { bis }}$.

\section{RECAPITULACIÓN}

La integración de España en la Comunidad Europea ha hecho necesario el estudio del ordenamiento jurídico comunitario y sus características, poniendo especial atención en los problemas derivados de la interrelación entre el Derecho comunitario y el Derecho estatal, partiendo de que uno y otro son derecho aplicable en nuestro pais.

Hemos visto en las páginas anteriores cómo esa integración, con apoyo constitucional en el artículo 93, supone la aceptación de la primacía del Derecho comunitario en aquellas materias en las que la compe-

72 TJCE, sentencia de 2 de febrero de 1982, asunto 73/1981, Comisión/Bélgica. En el mismo sentido, sentencia de 5 de marzo de 1970, asunto 77/69, Comisión/Bélgica. También sobre esta cuestión me remito a mi trabajo "Comunidades Autónomas y Derecho Comunitario Europeo", op. cit.

72 bis (1994) Cabe hacer también aquí una breve referencia al tema de la PARTICIPACIÓN DE LAS COMUNIDADES AUTÓNOMAS EN LA ADOPCIÓN DE DECISIONES COMUNITARIAS. Sobre todo, a la luz de la puesta en funcionamiento del COMITÉ DE LAS REGIONES, figura prevista en el artículo G.4 del Tratado de la Unión Europea. (Véase también el art. G.198.A, sobre la composición de este órgano, formado por representantes de los entes regionales y locales.) Sobre las competencias, meramente consultivas, de esta figura, y sobre la creciente presencia de las Comunidades Autónomas en la Unión Europea, me remito de nuevo a mi trabajo "Comunidades Autónomas y Derecho Comunitario Europeo", op. cit. A lo allí expuesto hay que añadir la referencia a una reciente sentencia de 26 de mayo de 1994, en la que el Tribunal Constitucional reconoce la competencia de las Comunidades Autónomas para mantener relación directa con las instituciones de la Unión Europea, a pesar de la titularidad del Estado en materia de relaciones internacionales. El ponente de la sentencia fue el vicepresidente del Tribunal Constitucional, profesor López Guerra.

En concreto, el Tribunal declara que corresponde al País Vasco la organización de un gabinete para asuntos relacionados con la Unión Europea, y el establecimiento de una oficina en Bruselas. Resuelve asi el Tribunal el conflicto promovido por el Gobierno central. En la sentencia se señala que «no puede en forma alguna excluirse que, para llevar a cabo correctamente las funciones que tenga atribuidas, una Comunidad Autónoma haya de realizar determinadas actividades no ya sólo fuera de su territorio, sino incluso fuera de los límites territoriales de Españan. La sentencia declara que las Comunidades Autónomas podrán «llevar a cabo actividades con alguna proyección externa". Ahora bien, "no podrán celebrar tratados o convenios con otros Estados o instituciones internacionales, ni realizar actuaciones que originen obligaciones al Estado frente a poderes públicos extranjeros o incidan en su política exterior". (Véase El País, 31 de mayo de 1994.) 
tencia haya sido transferida, y cómo el Tribunal de Justicia encomienda a los Jueces y Tribunales estatales la misión de asegurar esa primacía. Nos hemos referido, además, al recurso prejudicial como cauce de comunicación entre los órganos jurisdiccionales ordinarios y el Tribunal de Justicia de la Comunidad Europea.

El Tribunal Constitucional viene mostrándose contrario a utilizar la vía del recurso prejudicial, por entender que no está llamado a aplicar la normativa comunitaria.

La primacía, en definitiva, aparece como un instrumento que tiene su origen en la jurisprudencia del TJCE y que está al servicio del logro de los objetivos comunitarios. La aceptación de la misma por parte de los Estados conlleva la remoción de los esquemas constitucionales tradicionales. Así, en la actualidad, a la hora de estudiar aspectos como la organización territorial del Estado y consiguiente distribución de competencias, o la garantía de los derechos fundamentales, no puede dejar de tenerse en cuenta la realidad comunitaria.

En cuanto al último de estos aspectos, la Comunidad viene preocupándose por proteger los derechos fundamentales de sus ciudadanos, considerando esos derechos como principios generales del ordenamiento comunitario y como límite a la actuación de las instituciones de la Comunidad.

Respecto de la organización territorial del Estado, nos hemos referido a la obligatoria aplicación del Derecho comunitario por los órganos estatales centrales y también por los autonómicos. En este sentido, el logro de los objetivos europeos y la correcta aplicación del Derecho comunitario requiere una activa participación por parte de los Estados miembros.

Como hemos visto, la integración europea viene a alterar las concepciones tradicionales de la soberanía estatal, aunque se mantenga la noción de Estado democrático de Derecho. Lo que esta integración persigue es una unión que trasciende ya del ámbito puramente económico y avanza decididamente hacia la unidad política.

En la medida en que se vayan alcanzando logros en ese camino hacia la unión política, podrá irse abandonando la idea de una cesión de soberanía de los Estados a la Comunidad, para pasar a hablar de un ejercicio conjunto de una soberanía común. Sin embargo, como muestran los debates suscitados en los Estados miembros en torno al Tratado de là Unión Europea, las estructuras estatales de los Estados miembros no parecen suficientemente arraigadas como para que un Estado europeo único no sea posible a corto plazo. 


\section{ANEXO}

\section{LA DECLARACIÓN DE 1 DE JULIO DE 1992 Y EL CONTROL PREVIO DE CONSTITUCIONALIDAD DE LOS TRATADOS INTERNACIONALES}

Una vez terminadas y enviadas estas páginas, el Tribunal Constitucional ha respondido, mediante la Declaración de 1 de julio de 1992, al requerimiento formulado por el Gobierno de la Nación sobre la necesidad o no de modificar nuestra Constitución como paso previo a la ratificación del Tratado de la Unión Europea, firmado en Maastricht el pasado 7 de febrero ${ }^{73}$.

Ya con anterioridad al requerimiento del Gobierno, e incluso antes de la firma del Tratado, diversos autores se habían pronunciado a favor y en contra de la necesidad de reforma constitucional.

La cuestión, como se sabe, se planteaba en relación con el derecho de sufragio pasivo de los ciudadanos de los países comunitarios en las elecciones municipales, en cuanto que el Tratado de la Unión Europea supone un avance en el proceso de integración política, al instituir una "ciudadanía de la Unión», diferenciada de las de los Estados miembros y supraordinada a las mismas.

En este sentido, el precepto comunitario establece que «todo ciudadano de la Unión que resida en un Estado miembro del que no sea nacional tendrá derecho a ser elector y elegible en las elecciones municipales del Estado miembro en el que resida, en las mismas condiciones que los nacionales de dicho Estado...".

Frente a ello, el artículo 13.2 de la Constitución española de 1978 únicamente atribuye a los extranjeros el derecho a ser elector en las elec-

73 En su reunión de 24 de abril del presente año, el Consejo de Ministros acordó requerir al Tribunal Constitucional, iniciando así el procedimiento previsto en el artículo 95 de la Constitución y desarrollado en el artículo 78 de la Ley Orgánica del Tribunal Constitucional, con el fin de que el Tribunal se pronunciara sobre la eventual contradicción entre el artículo $8 \mathrm{~B}$, apartado 1, del Tratado constitutivo de la Comunidad Económica Europea -en la redacción que resultaría del artículo G B, 10, del Tratado de la Unión Europea-, y el artículo 13.2 de nuestra Constitución. El requerimiento (Asunto 1236/92) entró en el Tribunal el 13 de mayo de 1992. Ante este requerimiento, el Tribunal emitió su Declaración el día 1 de julio de 1992. Fue ponente de la misma el Magistrado D. Vicente Gimeno Sendra. La resolución no incorpora votos particulares.

Sobre esta Declaración, véase también mi trabajo El control previo de constitucionalidad. Estudio comparativo, de próxima publicación. 
ciones municipales, quedando, por tanto, excluido el derecho de sufragio pasivo ${ }^{74}$.

No es nuestro objetivo profundizar en el estudio del ejercicio del derecho de sufragio en España por parte de los no nacionales, ni tampoco en la cuestión de si realmente existía contradicción entre el artículo G B, apartado 10, del Tratado de la Unión Europea y el artículo 13.2 de nuestro texto constitucional, ni si la reforma debería haber afectado o no a otros preceptos.

Como es sabido, el Tribunal Constitucional sí ha apreciado la existencia de contradicción entre el precepto comunitario y el artículo 13.2 de la Constitución, estableciendo que para obtener la adecuación de aquéla ésta es necesario proceder a la reforma constitucional por la vía del artículo $167^{75}$.

74 El artículo 13.2 de la Constitución, tal y como fue redactado por el constituyente de 1978, establece: "Solamente los españoles serán titulares de los derechos reconocidos en el artículo 23, salvo lo que, atendiendo a criterios de reciprocidad, pueda establecerse por tratado o ley para el derecho de sufragio activo en las elecciones municipales". Sobre el derecho de sufragio de los extranjeros se ha ocupado recientemente M. D. AdAM MunOz, «El derecho de sufragio de los extranjeros residentes en España", Boletín informativo Colex Data, n.o 1, abril de 1992, págs. 11-20.

Las diversas opiniones doctrinales, tanto de los partidarios de la reforma como de los que no la estimaban necesaria, han sido recogidas por E. ARNALDO AlCUBILLA, "El derecho de sufragio de los extranjeros en las elecciones locales", Revista Española de Derecho Constitucional, n.o 34, enero-abril de 1992, págs. 67-97, especialmente págs. 92 y ss. A esta cuestión nos hemos referido ya someramente en la nota 52 de este trabajo.

Por otra parte, el Gobierno, durante la negociación del Tratado, había recabado el dictamen del Consejo de Estado, cuya Comisión Permanente dictaminó, el 20 de julio de 1991, que bastaría una ley orgánica para autorizar la celebración del Tratado, al amparo del artículo 93 de la Constitución. Un segundo dictamen del Consejo de Estado, de 9 de abril de 1992, reiteraba esta opinión.

75 La Declaración del Tribunal Constitucional recoge, en el punto 3 de los Antecedentes, los argumentos que, en su requerimiento, esgrimió el Gobierno de la Nación en favor de mantener intacto el texto constitucional, argumentos basados fundamentalmente en la suficiencia del mecanismo previsto en el artículo 93, y en el hecho de que el artículo 11 de la Constitución encomienda al legislador la regulación de la nacionalidad, siendo posible acudir a la técnica de las ficciones jurídicas para que, en esta materia, los ciudadanos de la Unión residentes en España seean equiparados a los ciudadanos españoles. Además, a juicio del Gobierno, en caso de que la reforma constitucional fuera necesaria, el procedimiento empleado debería ser el recogido en el artículo 167. Es decir, que la reforma no debería afectar al artículo 23 de la Constitución, ya que el constituyente de 1978 distinguió entre el derecho a la participación política (art. 23) y el círculo de sujetos legitimados para su ejercicio (arts. 23 y 13.2), teniendo además en cuenta que la extensión a los ciuda- 
Nuestro interés por esta Declaración reside sobre todo en el hecho de que se trata del primer supuesto de control previo de constitucionalidad de tratados internacionales que resuelve nuestro Tribunal Constitucional. Ello supone la primera aplicación práctica del procedimiento recogido en el artículo 95 de la Constitución, precepto en buena medida

danos comunitarios del derecho de sufragio pasivo en elecciones municipales no menoscaba el núcleo esencial del derecho de participación política. Además, según opinión del Gobierno, tal y como se recoge en los Antecedentes de la Declaración, «...el carácter reflejo del derecho de participación respecto al principio de soberanía popular no puede alterar su contenido de modo que éste quede configurado como una facultad de disposición sobre una parte alícuota de la soberanía que el ciudadano ostenta en cuanto parte integrante del pueblo".

Asimismo, en el punto 2 de los Antecedentes se recoge cómo el Gobierno realiza su propia valoración sobre el procedimiento de los artículos 95 de la Constitución y 78 LOTC, señalando que "no se trata de un procedimiento contencioso, sino de la solicitud de un dictamen", en la que "pueden integrarse opiniones de quien solicita el pronunciamiento". Parece lógico, en efecto, que el órgano requirente pueda formular opiniones para fundamentar jurídicamente sus pretensiones, si bien, el propio artículo 78. 2 LOTC prevé un momento para formular "opinión fundada sobre la cuestión" que parece más adecuado que el escogido por el requirente en este caso (así, según se observa en el punto 8 de los Antecedentes, el Gobierno "no formula opinión fundada en el trámite del artículo 78. 2", remitiéndose a los argumentos ofrecidos en el Acuerdo que dio lugar al requerimiento). El Tribunal responde, a lo largo de sus fundamentos jurídicos de esta Declaración, a todos esos argumentos esgrimidos por el Gobierno. La opinión del órgano requirente sobre la naturaleza jurídica de este procedimiento, es rebatida por el Tribunal en los términos que veremos más adelante.

Por su parte, el Tribunal Constitucional sólo consideró necesaria, para la adecuación del Tratado a la Constitución, la reforma del artículo 13.2 de la misma.

En efecto, en la Declaración se señala (FJ 3), remitiéndose a lo establecido en la Sentencia 112/1991, que la posibilidad del ejercicio del derecho de sufragio por parte de los no nacionales, en los términos del artículo 13.2, está limitada al derecho de sufragio activo. "... No cabe, pues, ni por tratado ni por ley, atribuir el derecho de sufragio pasivo a los no nacionales...". Por ello -estima el Tribunal-, el texto comunitario «...contiene una estipulación que, por contraria a la Constitución, no podría ser objeto de ratificación sin la previa revisión de la norma fundamental...".

Respecto del artículo 23, señala el Tribunal que ues una concreción del principio general de igualdad», en el que la interdicción de la discriminación se refiere a los ciudadanos, $y$ uno contiene, por tanto, ninguna otra norma que excluya a los extranjeros del acceso a cargos y funciones públicas".

Por último, respecto del otro precepto constitucional al que -según el Tribunal- habría podido afectar la extensión del derecho de sufragio pasivo a los no nacionales en las elecciones municipales, el artículo 1.2, el Tribunal señala que la proclamación que contiene este precepto sólo se vería afectada si los órganos en relación con los cuales operara la extensión del derecho de sufragio "...fueran de aquellos que ostentan potestades atribuidas directamente por la Constitución y los Estatutos de Autonomía y ligadas a la titularidad por el pueblo español de la soberania", órganos entre los cuales, dice el Tribunal, no cabe incluir a los municipios. 
cercano al artículo 54 de la Constitución francesa de 1978 y desarrollado por el artículo 78 LOTC.

Además, al responder por vez primera a este tipo de requerimiento, la Declaración del Tribunal Constitucional ha venido a afirmar una vez más el carácter de la Constitución como norma suprema y ha clarificado el alcance de los artículos 93 y 95 del texto constitucional.

Estos aspectos serán los que centren nuestra atención en las consideraciones siguientes.

En efecto, se consideró necesario realizar en la Declaración "alguna consideración previa sobre el procedimiento regulado en aquellas normas y sobre la cuestión que ha sido sometida al examen de este Tribunal" (FJ 1).

Las consideraciones del Tribunal Constitucional acerca del procedimiento de control previo de tratados internacionales podrían ser resumidas en dos afirmaciones esenciales.

Por una parte, el Tribunal mantiene que estamos ante un procedimiento jurisdiccional de control de constitucionalidad.

Por otra, se afirma que la finalidad de este procedimiento es garantizar la supremacía de la Constitución, garantizando al mismo tiempo la seguridad y estabilidad de los compromisos internacionales.

En realidad, de la primera de estas afirmaciones sigue lógicamente la segunda, ya que el control de constitucionalidad es un medio de defensa de la Constitución, cuya razón de ser consiste precisamente en asegurar el papel de supremacía de la Constitución sobre el resto del ordenamiento jurídico.

\section{A) EL CONTROL PREVIO DE TRATADOS COMO CONTROL JURISDICCIONAL DE CONSTITUCIONALIDAD}

En cuanto al primero de los aspectos señalados, se observa, en efecto, cómo el Tribunal Constitucional afirma la naturaleza jurisdiccional de la función de control previo de constitucionalidad de los tratados in:ternacionales que le asigna el artículo 95 de la Constitución, así como de la decisión que pone fin al procedimiento. No se trata, pues, de una actividad de carácter consultivo: 
"Lo que de nosotros puede solicitarse es una declaración, no un dictamen; una decisión, no una mera opinión fundada en Derecho. Este Tribunal no deja de serlo para transformarse ocasionalmente, por obra del requerimiento, en cuerpo consultivo. Lo que el requerimiento incorpora es, al igual que acontece en las cuestiones de inconstitucionalidad, la exposición de una duda razonable, pero de lo que nosotros se solicita no es un razonamiento que la resuelva, sino una decisión vinculanten ${ }^{76}$.

76 Salvo indicación en contrario, los fragmentos de la Declaración que a partir de aqui reproducimos pertenecen a su FJ 1. Los subrayados son nuestros.

En cuanto a la naturaleza jurisdiccional (afirmada contundentemente por el Tribunal en esta Declaración) o consultiva del control previo de constitucionalidad de tratados internacionales previsto en nuestro ordenamiento, la doctrina ha mantenido opiniones de signo distinto. Citamos algunas a modo de ejemplo.

J. González Pérez, Derecho procesal constitucional, Madrid, Civitas, 1980, págs. 269-270, señala que uel Tribunal Constitucional, al conocer de la posible contradicción entre las estipulaciones de un tratado internacional y la Constitución, no realiza una actividad propiamente jurisdiccional o procesal, no examina una pretensión procesal que un sujeto deduce frente a otro, sino una actividad consultiva a requerimiento de determinados órganos del Estado, cualificada por la naturaleza del acto a que se refiere y la trascendencia de sus efectos". Este autor (ibidem, pág. 273) se refiere a la decisión del Tribunal como a una "opinión vinculante".

Por su parte, P. CRUz VILlalón, "El control previo de constitucionalidad", $R e$ vista de Derecho Público, 2. época, n. 9 82, enero-marzo de 1981, págs. 5-21, concretamente págs 8 y ss., afirma el carácter vinculante del control, aunque lo relativiza: "...Dicho carácter vinculante sólo opera en el conjunto de la mecánica del artículo 95 (...). No, por tanto, en el sentido de que la declaración excluya el control sucesivo del tratado...n. Este autor define este procedimiento señalando que "... nos hallamos más bien ante una actividad consultiva, un dictamen en el que todos los legitimados para solicitarlo pueden manifestar su opinión al respecto, pudiendo el Tribunal solicitar cuantas aclaraciones, etc., estime necesarias...". Y añade: "Es un simple instrumento facultativo, aunque vinculante, en orden a colocar al legislador en la via correcta para incorporar un determinado tratado al ordenamiento del Estado".

J. Almagro Nosete y P. Saavedra Gallo, Justicia constitucional (Comentarios a la Ley Orgánica del Tribunal Constitucional), Valencia, Tirant lo Blanch, 2. edición, 1989, pág. 498, señalan: "No puede decirse que propiamente subyazca un conflicto en este proceso. En realidad, lo que se formula es una consulta que se resuelve conforme a formas procesales $y$, aunque los efectos sean vinculantes, la litigiosidad no se produce. Su encuadre no es el de un proceso contencioso. Es un negocio de jurisdicción voluntaria constitucional».

J. Rodriguez-Zapata y Pérez, "Los tratados internacionales y los controles de constitucionalidad", en VV.AA., EI Tribunal Constitucional, Madrid, Dirección General de lo Contencioso del Estado, Instituto de Estudios Fiscales, 1981, págs. 23612410 , concretamente pág. 2370 , sí admite la jurisdiccionalidad de este proceso señalando que, si bien puede ser necesario revisar algunos conceptos, «si el Tribunal Constitucional es un órgano jurisdiccional, en lo que no creo que existan discrepancias serias en nuestra doctrina, el control previo sobre los tratados puede ser construido también como función jurisdiccional». Según este autor (ibidem, pág. 2371), "puede ser que nos encontremos en la frontera de lo consultivo, pero, como 
Tras esta delimitación respecto de la actividad consultiva -cuestión a la que volveremos a referirnos más adelante-, el Tribunal continúa fundamentando el carácter jurisdiccional de su actuación en estos supuestos:

«Por ello, y aun cuando este procedimiento no haya de poseer necesariamente naturaleza contenciosa, no por dicha circunstancia se ve alterada la posición del Tribunal como intérprete supremo de la Constitución. Al igual que en cualquier otro cauce, el Tribunal actúa aquí como el órgano jurisdiccional que es, y su declaración, por tanto, no puede sino basarse en argumentaciones jurídico-constitucionales..."

En definitiva, el Tribunal afirma que nos hallamos ante un supuesto más de control de constitucionalidad que, al igual que los demás, reviste carácter jurisdiccional, no teniendo por qué tratarse, para recibir tal consideración, de un proceso entre varias partes enfrentadas ${ }^{77}$.

nos ha enseñado García dE EnTERRÍA [cita a E. García de Enterría, La Administración española, Madrid, 1963, in nota a páginas 79 y ss.], el límite con lo jurisdiccional es siempre bastante impreciso. Nadie ha negado, hasta ahora, carácter jurisdiccional, como verdadero proceso constitucional, al surgido de la cuestión de inconstitucionalidad. Pero dicha cuestión podría ser atraida a la esfera de lo consultivo con los mismos argumentos con los que se ha argumentado sobre el control previo sobre los tratados".

Por su parte, E. Álvarez Conde, El régimen político español, Madrid, Tecnos, 4.` edición, 1990, pág. 565, opina que el Tribunal ejerce en estos casos una función jurisdiccional, "...ya que se trata de zanjar una litis potencial y la declaración tiene efectos vinculantes".

También en favor de la naturaleza jurisdiccional, M. Montoro PUERTO, Jurisdicción constitucional $y$ procesos constitucionales. Tomo I: Jurisdicción constitucional y procesos de control de la constitucionalidad, Madrid, Colex, 1991, pág. 316, el cual cita el auto del TC 98/1981, de 30 de septiembre, en el que el Tribunal niega poseer funciones consultivas. Según este autor, la decisión del Tribunal en estos casos sería, en realidad, una sentencia, ya que, según el artículo 86.1 LOTC, "la decisión del proceso constitucional se producirá en forma de sentencia". Así, la decisión será una declaración en cuanto a su contenido ("para que declare», art. 95.2 CE), pero una sentencia en cuanto a la forma. Este argumento es especialmente compartible una vez que se ha producido la Declaración de 1 de julio de 1992, puesto que a pesar de llevar el nombre de "declaración", se asemeja en buena medida a una sentencia, como vamos a comprobar.

77 Respecto de las peculiaridades que el tema de las partes presenta en los procesos constitucionales, pueden verse J. GonZÁLEZ PÉREZ, Derecho procesal constitucional, op. cit., en nota 76, págs. 101 y ss., 253-254 y 263 y ss. Asimismo, J. ALmagro Nosete y P. SaAvedra Gallo, Justicia constitucional (Comentarios a la Ley Orgánica del Tribunal Constitucional, op. cit., en nota 76, págs. 208 y 235 y ss.

Lo que sí existe en el caso que nos ocupa es, evidentemente, un conjunto de pretensiones por parte del órgano requirente, como ya hemos apuntado. Ello va ló- 
Continúa el Tribunal fundamentando el carácter jurisdiccional de su actividad en estos supuestos mediante la enumeración de una serie de características propias de la función jurisdiccional que se dan en este y en los demás procedimientos de declaración de inconstitucionalidad:

«...El artículo 95.1 (...) ha reservado en exclusiva al Gobierno y a una u otra de ambas Cámaras la facultad de formular esta duda de constitucionalidad, cuyo planteamiento y elucidación ex officio no le corresponde, por tanto, al Tribunal, el cual, al igual que en los demás procedimientos, carece de iniciativa y está vinculado al principio constitucional de congruencia. Ello sin perjuicio de que este Tribunal pueda solicitar nuevas informaciones y aclaraciones o ampliaciones de conformidad con el artículo 78.3 de la LOTC.

Pero, en cualquier caso, bien que la resolución emanada de este Tribunal confirme la constitucionalidad de la norma convencional objeto de examen, bien declare, por el contrario, su contradicción con nuestra Ley Fundamental, dicha resolución posee los efectos materiales de la cosa juzgada.1 ${ }^{78}$

Todos estos argumentos sirven para reforzar el que el Tribunal había resaltado en primer lugar: este órgano continúa siendo un tribunal en estos supuestos: "El Tribunal actúa aquí como el órgano jurisdiccional que es".

Creemos que estos planteamientos del Tribunal Constitucional han de considerarse correctos. En efecto, no hay, en el procedimiento que aquí estudiamos, ningún elemento que permita hablar de un cambio

gicamente unido a la propia idea de requerimiento. Se requiere al órgano jurisdiccional para obtener una decisión que satisfaga los intereses y las pretensiones del requirente.

78 El Tribunal considera que su decisión produce «todos los efectos de la cosa juzgada, tanto los negativos o excluyentes, que impedirían trasladar a este Tribunal la estipulación objeto de la resolución a través de los procedimientos de declaración de inconstitucionalidad, cuanto los positivos o prejudiciales que han de obligar a todos los poderes públicos a respetar y ajustarse a nuestra declaración".

Además, se trata de una decisión vinculante que produce efectos erga omnes, cuestión sobre la que volveremos más adelante.

Por otra parte, es obvio que también respecto de este procedimiento de los artículos 95 de la Constitución y 78 de la LOTC ha de considerarse aplicable el artículo 22 de la Ley orgánica, que contiene lo que podrían llamarse principios ordenadores de la jurisdicción constitucional: "Los Magistrados del Tribunal Constitucional ejercerán su función de acuerdo con los principios de imparcialidad y dignidad inherentes a la misma; no podrán ser perseguidos por las opiniones expresadas en el ejercicio de sus funciones; serán inamovibles y no podrán ser destituidos ni suspendidos sino por algunas de las causas que esta Ley establece». 
de naturaleza o "desaparición» de la naturaleza jurisdiccional con respecto a las restantes competencias de control de constitucionalidad, en cuyo ejercicio no se duda del carácter jurisdiccional del Tribunal ${ }^{79}$.

El Tribunal añade, en este sentido, una consideración más, por si la propia denominación del texto que estamos comentando («declaración" y no "sentencia") pudiera hacer dudar de su carácter jurisdiccional:

"Aunque la forma de dicha declaración no pueda merecer la calificación legal de "sentencia" (cfr. artículo 86.2. LOTC), es una decisión jurisdiccional con carácter vinculante (art. $78.2 .^{\circ}$ id.) y, en cuanto tal, produce "erga omnes" (art. 164.1. "in fine" CE) todos los efectos de la cosa juzgada...".

Para empezar, y al igual que en las sentencias en las que se decide sobre la constitucionalidad de una norma, la decisión corresponde al Pleno [art. 10.d) LOTC].

Incluso formalmente, esta decisión del Tribunal Constitucional se asemeja a una sentencia.

En efecto, al igual que en las sentencias, en el encabezamiento anterior a los antecedentes, la única variación es la sustitución de la palabra "sentencia" por "declaración». Se mantiene, además, la estructura utilizada en las sentencias, a saber, un apartado "I. ANTECEDENTES", seguido del "Il. FUNDAMENTOS JURÍDICOS". La declaración termina igual que las sentencias, es decir, con la DECISIÓN DEL TRIBUNAL, si bien en la declaración que ahora comentamos no aparece expresamente la palabra "FALLO", y en lugar de la fórmula "Ha decidido:», se emplea la fórmula "Declara:". En cumplimiento del artículo 86.2 LOTC, se añade: «Publíquese esta Declaración en el Boletín Oficial del Estado". En definitiva, es la misma estructura de una sentencia: (a) los antecedentes, y (b) los razonamientos que conducen a (c) la decisión.

Por otra parte, en cuanto al carácter vinculante y los efectos erga omnes, de obligatorio cumplimiento para todos los poderes públicos, no

79 El Tribunal Constitucional debe ser considerado como un auténtico trịbunal, si bien se trata de un tribunal especial, sobre todo por las peculiaridades de su composición. La caracterización del Tribunal Constitucional como utribunal especial" puede verse, por ejemplo, en V. Gimeno SEndra, Constitución y proceso, Madrid, Tecnos, 1988, págs. 212-214. Asimismo, M. GARCiA ARÁN, La prevaricación judicial, Madrid, Tecnos, 1990, pág. 57. 
existe tampoco diferencia respecto de las sentencias. De hecho, a este respecto, en el fragmento que hemos transcrito, el Tribunal se remite al artículo 164 de la Constitución, precepto referido, literalmente, a «las sentencias del Tribunal Constitucional...." ${ }^{80}$.

Se trata, en definitiva, de un proceso más de control de constitucionalidad. Control que, para más señas, es de carácter abstracto.

En efecto, al hablar del alcance de su actuación en este proceso, el Tribunal señala:

«...Su examen debe ceñirse (...) al contraste entre la Constitución y cualquiera de sus enunciados, y la estipulación o estipulaciones del tratado que hayan sido sometidas a control previo...." ${ }^{81}$.

so Incluso la ausencia de la palabra "fallo" en el texto de la Declaración podría entenderse relativizada a la vista del artículo 86.2 LOTC, que emplea el término "fallo" sin distinguir entre ambas categorías de resoluciones: "Las sentencias y las declaraciones a que se refiere el Título VI de esta Ley se publicarán en el "B.O.E." dentro de los treinta días siguientes a la fecha del fallo».

Por otra parte, no sería argumento para negar el carácter jurisdiccional de esta decisión el tenor del artículo 245.1 de la Ley Orgánica 6/1985, de 1 de julio, del Poder judicial. Según este precepto, las resoluciones de los Jueces y Tribunales que tienen carácter jurisdiccional se denominan providencias, autos o sentencias. Pero hay que tener en cuenta que el Tribunal Constitucional es un Tribunal especial, fuera del Poder judicial. Y si bien el artículo 80 LOTC señala que la LOPJ se aplicará con carácter supletorio, a la "...publicidad y forma de los actos", no hay que olvidar que las normas supletorias son las que se aplican en defecto de disposiciones expresas. Lo cual no sucede en el caso que nos ocupa, puesto que el acto jurisdiccional y vinculante del Tribunal Constitucional denominado "Declaración" se encuentra expresamente previsto en los artículos 78.2 y 86.2 LOTC.

A la obligatoriedad para los poderes públicos se refiere expresamente el Tribunal Constitucional, al hablar de los efectos positivos o prejudiciales de cosa juzgada de su Declaración, los cuales uhan de obligar a todos los poderes públicos a respetar y ajustarse a nuestra declaración; en particular, si su contenido fuera el de que una determinada estipulación es contraria a la Constitución, el efecto ejecutivo inmediato $y$ directo ha de ser el de la reforma de la Constitución con carácter previo a la aprobación del tratadon.

${ }_{81}$ En este mismo sentido se pronuncia el Tribunal en otro momento de la Declaración, al referirse a la exposición de peticiones que contenía el requerimiento del Gobierno.

En este requerimiento se solicitaba del Tribunal que emitiera su declaración vinculante sobre tres extremos (véase punto 4 de los Antecedentes): en primer lugar, la constitucionalidad del recurso al artículo 93 y su adecuación y suficiencia para obligarse por el Tratado de Maastricht, sin reformar la Constitución. En segundo lugar, la existencia o no de contradicción entre el precepto comunitario y el artículo 13.2 de la Constitución, y la legitimidad o no de la interpretación del artículo 11 de la Constitución realizada por el Gobierno en el escrito de requerimiento. En ter- 
Vemos, entonces, que la actividad que el Tribunal realiza consiste en el examen de dos normas - la Constitución y el texto del tratado- para detectar posibles contradicciones entre ambas. Ésta es, entonces, la misma labor que el Tribunal realiza al decidir los recursos y cuestiones de inconstitucionalidad ${ }^{82}$.

cer lugar, se pedía al Tribunal que, en caso de estimar necesaria la reforma constitucional a pesar de los argumentos esgrimidos en el requerimiento, se pronunciara sobre la idoneidad de la vía del artículo 167 de la Constitución para llevar a cabo la reforma.

Pues bien, a estas pretensiones responde el Tribunal (FJ 2) diciendo que "la anterior exposición de peticiones, sucesivas y subsidiarias, no puede ser acogida. De conformidad con lo dispuesto en el artículo 95.1. de la CE (...), la primera cuestión, decisiva y nuclear, a tratar en esta declaración es la de determinar si entre el precepto objeto de nuestro examen y el artículo 13.2. de la Constitución u otros preceptos de la Constitución existe o no aquella contradicción...".

Añade el Tribunal que su examen ha de versar sobre "la eventual contradicción del futuro artículo 8.b.1.del TCEE con la Constitución, y no tan sólo con el artículo 13.2. - de la misma (único precepto individualizado en el petitum del escrito del Gobierno), pues es, como se ha dicho, la Constitución in toto, y no sólo alguno de sus preceptos, la que ha de erigirse en punto de referencia por este Tribunal». Por eso, la declaración "...no puede sino basarse en argumentaciones jurídico-constitucionales, hayan sido éstas sugeridas o no por el órgano solicitante o por los demás que están legitimados." "

Parece que estas afirmaciones han de ponerse en conexión con el artículo 39.2 LOTC, el cual, como se ha señalado, no significa una excepción al principio de congruencia, sino una manifestación del iura novit curia. Véase, a este respecto, J. ALmAGro Nosete y P. SaAvedra Gallo, Justicia constitucional (Comentarios a la Ley Orgánica del Tribunal Constitucional), op. cit., en nota 76, págs. 252 y ss.

82 Entendemos aquí el "control abstracto», en un sentido en buena medida kelseniano, como aquel en el que el Tribunal compara la Constitución y la norma sometida a examen, pudiendo declarar, en su caso, la inconstitucionalidad de ésta con efectos erga omnes. Esta característica es común al recurso y a la cuestión de inconstitucionalidad, independientemente de que se haya dado en llamar a ésta "control concreton al plantearse con ocasión de la aplicación de la ley en un litigio. En el sentido en que aquí nos interesa, recurso y cuestión de inconstitucionalidad serían dos manifestaciones o vías (directa e incidental, respectivamente) para ejercer una misma función. Véase en tal sentido mi trabajo "Consideraciones sobre el control ejercido por los Tribunales Constitucionales: Las vías directa e incidental (“Control abstracto-control concreto")", Revista General de Derecho, n. 39, marzo 1994, págs. 1901-1918.

La Declaración del Tribunal que aqui comentamos pone de manifiesto cómo el procedimiento de control previo de tratados se asemeja al recurso y a la cuestión de inconstitucionalidad (arts. 31 y ss. LOTC), que a su vez aparecen de alguna manera equiparados. En efecto, la similitud con el recurso consiste en que en este procedimiento se contrasta la Constitución y el tratado a instancia de uno de los sujetos legitimados para formular esta «duda de constitucionalidad». Además, señala el Tribunal, «lo que el requerimiento incorpora es, al igual que en las cuestiones de inconstitucionalidad, la exposición de una duda razonable...".

A. REMIRo BRotons, "Controles preventivos y reparadores de la constitucionalidad intrínseca de los tratados internacionales", Revista de Derecho Político, n.o 16, invierno 1982-1983, págs. 109-141, concretamente pág. 121, señala cómo este control es "preventivo $-\mathrm{y}$, como tal, necesariamente abstracto-...". 
Como en el recurso y en la cuestión de inconstitucionalidad, la decisión del Tribunal es vinculante, y produce efectos erga omnes.

Existen, sin embargo, ciertas peculiaridades respecto de los efectos. Así, la declaración de inconstitucionalidad en el recurso y la cuestión llevan consigo la desaparición del ordenamiento de esa norma que, por contraria'a la Constitución, es nula.

Sin embargo, en el control previo de tratados, la contradicción con la Constitución no afecta al texto del tratado, sino a su aplicabilidad en el respectivo Estado. Para que el Estado pueda obligarse por el texto del Tratado, es la Constitución la que debe ser reformada.

Por tanto, si bien no podría hablarse propiamente de mecanismo por el que se pueda promover la declaración de inconstitucionalidad (la LOTC, en su artículo 29, sólo menciona en este sentido al recurso y a la cuestión de inconstitucionalidad), sí puede considerarse el control previo de tratados como un mecanismo de control de constitucionalidad.

En cualquier caso, este carácter de control de constitucionalidad se ve afirmado por consistir en una confrontación o análisis comparativo de ambas normas, dirigida a evitar la existencia de normas aplicables en España que contradigan la Constitución. Estamos, al igual que en el recurso y en la cuestión de inconstitucionalidad, ante una forma de depuración del ordenamiento, si bien se trata de una peculiar forma de depuración a priori ${ }^{83}$.

Por otra parte, el Tribunal actúa en este caso dentro de los límites que le marcan la Constitución y la Ley orgánica, sin que pueda decirse que se extralimita en sus funciones emanando una decisión "cuasilegislativa".

En efecto, el Tribunal no indica el contenido que debe tener el artículo 13.2 una vez reformado, ni siquiera dice que haya que proceder obligatoriamente a la reforma de la Constitución.

Así en la parte final de su Declaración se limita a declarar, a poner de manifiesto, que existe contradicción entre el artículo 8.B.1 del Tratado

83 Señala, a este respecto, J. Rodríguez Zapata y PÉRez, "Los Tratados internacionales y los controles de constitucionalidad", op. cit., en nota 76, pág. 2371, que «...en la hipótesis del artículo 78 de la LOTC no se tratará de eliminar una antinomia real, sino de comprobar (accertamento) la inconstitucionalidad virtual de determinados hechos o actos prenormativos que, si devienen normas [creemos que debe entenderse "normas aplicables en España»], serán inconstitucionales». 
y el artículo 13.2 de la Constitución. Y, al señalar que el precepto constitucional afectado es el artículo 13.2, añade, como consecuencia lógica que se deduce de la misma lectura del texto constitucional, que el procedimiento para revisar este artículo es el establecido en el artículo 167 . Pero no obliga a esa reforma. Sólo declara que éste será el procedimiento a seguir "para obtener la adecuación de dicha norma convencional a la Constitución».

Vemos, pues, que el Tribunal se mantiene dentro de los límites de lo que es y significa el control de constitucionalidad ${ }^{84}$.

Estas consideraciones nos llevan a referirnos a la finalidad del control previo de tratados tal y como el Tribunal lo concibe en esta Declaración. Al tratarse de un mecanismo de control de constitucionalidad, su principal objetivo será el mismo que constituye la razón de ser de la justicia constitucional: la defensa de la Constitución, mediante la garantía de su posición de norma jurídica suprema.

\section{B) EL CONTROL PREVIO DE TRATADOS COMO MEDIO DE DEFENSA DE LA CONSTITUCIÓN}

En las consideraciones que el Tribunal realiza en el fundamento jurídico primero de su Declaración, queda claramente establecida la finalidad del control previo de Tratados:

"Mediante la vía prevista en su artículo 95.2, la Norma fundamental atribuye al Tribunal Constitucional la doble tarea de preservar la Constitu-

${ }^{84}$ Aun así, el Tribunal, una vez que el Tribunal ha puesto de manifiesto la contradicción entre el precepto comunitario y el artículo 13.2 de la Constitución, se considera obligado a responder a las alegaciones del órgano requirente (véanse FJ 3 in fine y FF.JJ. 4 y ss.). Parece que el Tribunal, en su papel de "intérprete supremo de la Constitución", considera que no debe dejar de plasmar aquí su interpretación de determinados preceptos constitucionales (fundamentalmente los artículos 93, 95 y 11 del texto constitucional), dando así respuesta a otras interpretaciones. En efecto, según el Tribunal, "con lo dicho, y constatada la existencia de una antinomia entre el futuro artículo 8.B.1 del TCCEE y el artículo 13.2. $\mathrm{CE}$, de conformidad con lo preceptuado en su artículo $95.1 . \%$, podría finalizar aquí nuestra declaración. La alegación, sin embargo, por parte del Gobierno de otras interpretaciones, en su opinión superadoras de la advertida, ha de obligarnos a efectuar una adecuada respuesta a las mismas". 
ción y de garantizar, al tiempo, la seguridad y estabilidad de los compromisos a contraer por España en el orden internacional».

"...De este modo, la Constitución ve garantizada, a través del procedimiento previsto en su Título $X$, su primacía, adquiriendo también el tratado, en la parte del mismo que fue objeto de examen, estabilidad jurídica plena, por el carácter vinculante de la declaración del Tribunal (art. 78.2 de la LOTC), como corresponde al sentido de este examen preventivo.

Aunque aquella supremacía quede en todo caso asegurada por la posibilidad de impugnar (arts. 27.2.C, 31 y 32.1 LOTC) o cuestionar (art. 35 LOTC) la constitucionalidad de los tratados una vez que formen parte del ordenamiento interno (art. 96.1 CE), es evidente la perturbación que, para la política exterior y las relaciones internacionales del Estado, implicaría la eventual declaración de inconstitucionalidad de una norma pactada; el riesgo de una perturbación de este género es lo que la previsión constitucional intenta evitar."

Parece claro, entonces, que se trata de evitar la existencia de una norma vigente y aplicable en España que contradiga lo establecido en la Constitución, considerada como norma suprema ${ }^{85}$.

En relación con esta cuestión, el Tribunal plantea, como vemos, el tema de la justificación de este control previo, así como el de su coexistencia con el control sucesivo sobre los tratados internacionales.

El control previo encuentra justificación al pretender evitar las consecuencias que podría acarrear el control sucesivo para la estabilidad de nuestros compromisos internacionales. Según se desprende de los términos en que se expresa el Tribunal, lo que se busca es que no haya necesidad de llegar a ejercer el control sucesivo sobre tratados internacionales; no obstante, esta vía sucesiva, cuya utilización no es deseable, subsiste en el ordenamiento, como un medio más para asegurar la supremacía constitucional ${ }^{86}$.

85 No deja de ser significativo, a este respecto, que el Tribunal hable (véase FJ 6 y la parte final de la Declaración) de contradicción entre el Tratado y la Constitución, y no al revés. Es el artículo 8.B.1 del Tratado el que es contrario al artículo 13.2 de la Constitución. En otros párrafos reproducidos en este comentario, el Tribunal se expresa de la misma manera, hablando de eventual contradicción entre el Tratado y la Constitución.

${ }_{86}$ Esta justificación del control previo sobre tratados, basada en las dificultades e inconvenientes que supone un control sucesivo sobre tratados (a la vista, fundamentalmente, de lo dispuesto en el artículo 96 de la Constitución), ya había sido recogida con anterioridad por la doctrina. A este respecto puede verse, por ejemplo, E. Garcia de ENTERRÍA, La Constitución como norma y el Tribunal Constitucional, 
En cuanto a los problemas que puede plantear la coexistencia del control preventivo y el control sucesivo sobre tratados, hay que decir que se ven en buena medida mitigados a la vista de la Declaración del Tribunal que estamos comentando.

En efecto, puesto que el Tribunal puede examinar la adecuación del precepto impugnado del Tratado respecto de toda la Constitución, los efectos de cosa juzgada que caracterizan a la Declaración vienen a imposibilitar que el control sucesivo vuelva a plantearse respecto del mismo precepto del tratado que motivó el control preventivo ${ }^{87}$.

También en relación con la defensa de la Constitución como norma jurídica suprema el Tribunal realiza en su Declaración (sobre todo en FF.JJ. 4 a 6) una serie de consideraciones en las que define y delimita el alcance de los artículos 93 y 95 de la Constitución. Desempeña así el Tribunal su papel de intérprete supremo de la norma fundamental.

De estas consideraciones se desprende que el artículo 93 de la Constitución, precepto de engarce entre el ordenamiento interno y el comunitario, comparte este papel con el artículo 95.1. En efecto, el Tribunal señala que este último precepto de la Constitución, "por su generalidad, es de aplicación a todo tipo de tratados, incluidos los suscritos al amparo del artículo 93...".

Entre ambos preceptos se establece, así, una relación normativa en virtud de la cual el artículo 95 vendría a servir para que las previsiones constitucionales actúen como límite a la atribución del ejercicio de competencias que posibilita el artículo 93 .

Madrid, Civitas, 3. ${ }^{a}$ edición, 1985, págs. 155-156. Véase, asimismo, P. Cruz VILLalón, "El control previo de constitucionalidad", Revista de Derecho Público, 2." época, n. 82, enero-marzo de 1981, págs. 7 y ss.; A. J. GómEz MonToro, «El control previo de constitucionalidad de proyectos de Estatutos de Autonomía y demás Leyes orgánicas", Revista Española de Derecho Constitucional, n. 22, enero-abril de 1988, págs. 121-174, concretamente pág. 122, señala que el control previo sobre tratados viene justificado upor la peculiar naturaleza de este tipo de normas y por las implicaciones internacionales que acompañan a su régimen de modificación o derogación".

87 Al carácter problemático de la coexistencia de ambas modalidades de control se han referido, por ejemplo, E. Álvarez CONDE, El régimen político español, op. cit., en nota 76, pág. 566. Véase, además, A. Remiro Brotons, "Controles preventivos y reparadores de la constitucionalidad intrínseca de los tratados internacionales", op. cit., en nota 82, especialmente págs. 127 y ss.; M. MONTORo Puerto, Jurisdicción constitucional y procesos constitucionales. Tomo I, Jurisdicción constitucional y procesos de control de la constitucionalidad, op. cit., en nota 76, págs. 303 y ss. 
En este sentido, acerca del artículo 93, el Tribunal señala:

"....No es leve, desde luego, la complejidad que entraña este precepto "orgánico-procedimental" (STC 28/1991, FJ 4.9), que aquí ha de ser considerado, sin embargo, tan sólo en conexión con lo dispuesto en el artículo 95.1 de la Constitución...n (FJ 4).

Esa conexión viene dada por la finalidad - garantizar la supremacía constitucional- del procedimiento previsto en el artículo 95. Los tratados, "incluidos los suscritos al amparo del artículo 93", no pueden contradecir la Constitución. Sin perjuicio de los demás modos de control de constitucionalidad sobre los tratados, la función del artículo 95 consiste en que esa contradicción no llegue a producirse:

"...El tenor literal y el sentido mismo del artículo 95.1, aplicable a todo tipo de tratados, excluyen con claridad el que mediante cualquiera de ellos puedan llegar a ser contradichas o excepcionadas las reglas constitucionales que limitan, justamente, el ejercicio de todas las competencias que la Constitución confiere, algunas de las cuales pueden ser cedidas, quoad exercitium, en virtud de lo dispuesto en su artículo 93. Los poderes públicos españoles no están menos sujetos a la Constitución cuando actúan en las relaciones internacionales o supranacionales que al ejercer ad intra sus atribuciones, y no otra cosa ha querido preservar el artículo 95, precepto cuya función de garantía no debe resultar contrariada o disminuida por lo prevenido en el artículo 93 de la misma norma fundamental".

Por tanto, de acuerdo con estas consideraciones sobre el alcance y función de estos preceptos, la propia Constitución, preservada por el procedimiento previsto en su artículo 95, es la que marca los límites a la atribución del ejercicio de competencias en virtud del artículo 93: esa atribución será posible siempre que no se contradigan las previsiones constitucionales.

Por otra parte, de los argumentos expuestos por el Tribunal en este FJ 4 se extrae una idea que el Tribunal utiliza también en los fundamentos jurídicos posteriores: la rigidez constitucional actuaría (junto con la justicia constitucional según vimos) como medio de defensa de la Constitución: ${ }^{88}$

${ }_{88}$ A las funciones que cumple la reforma constitucional se refiere $P$. DE VEGA, La reforma constitucional y la problemática del poder constituyente, Madrid, 
"...Se ha de procurar, más bien, una interpretación que concilie ambas previsiones constitucionales; lo que supone afirmar, de una parte, que los enunciados de la Constitución no pueden ser contradichos sino mediante su reforma expresa (por los cauces del Título X) y reconocer también, de la otra, que cabe autorizar, mediante ley orgánica, la ratificación de tratados que, según quedó dicho, transfieran o atribuyan a organizaciones internacionales el ejercicio de competencias ex constitutione, modulándose así, por lo tanto, el ámbito de aplicación, no el enunciado, de las reglas que las han instituido y ordenado. Éste es, sin duda, un efecto previsto por la Constitución y, en cuanto tal, legítimo, pero ninguna relación guarda con el que depararía la colisión textual y directa entre la propia norma fundamental y una o varias de las estipulaciones de un tratado. Tal hipótesis - la del tratado contra Constitutionem- ha sido, en definitiva, excluida por el artículo 95".

En este sentido, el Tribunal establece que el artículo 93 no puede significar una vía para que se produzcan modificaciones no formales de la Constitución:

“Por lo demás, tampoco el artículo 93 de la Constitución se prestaría a ser empleado como instrumento para contrariar o rectificar mandatos o prohibiciones contenidos en la norma fundamental, pues, ni tal precepto es cauce legítimo para la "reforma implícita o tácita" constitucional, ni podría ser llamada atribución del ejercicio de competencias, en coherencia con ello, una tal contradicción, a través del tratado, de los imperativos constitucionales".

Estas mismas ideas aparecen expresadas de nuevo más adelante:

"En virtud del artículo 93, las Cortes Generales pueden, en suma, ceder o atribuir el ejercicio de "competencias derivadas de la Constitución", no disponer de la Constitución misma, contrariando, o permitiendo contrariar, sus determinaciones, pues ni el poder de revisión constitucional es una "competencia" cuyo ejercicio fuera susceptible de cesión, ni la propia Constitución admite ser reformada por otro cauce que no sea el de su Título $X$, esto es, a través de los procedimientos y con las garantías allí establecidos y mediante la modificación expresa de su propio texto. Ésta es la conclusión que impone el dictado del

Tecnos («Temas claves de la Constitución española»), 1985, especialmente en págș. 67 y ss. Según este autor, son tres las funciones que, en síntesis, vendría a desempeñar este instituto: "En primer lugar, como instrumento de adecuación entre la realidad jurídica y la realidad política. En segundo término, como mecanismo de articulación de la continuidad jurídica del Estado. Y, por último, como institución básica de garantía". 
artículo 95.1, sin que sea ocioso recordar que la operación consistente en excepcionar enunciados constitucionales a través de un tratado $(. .$. llegó a ser planteada y no fue acogida en el proceso constituyente (art. 55.3 del Anteproyecto de Constitución y, con otro alcance, enmienda núm. 343 de las presentadas en el Senado al Proyecto de Constitución)"1 ${ }^{89}$.

El Tribunal Constitucional utiliza los mismos argumentos en el fundamento jurídico 5, al responder a la propuesta del órgano requirente sobre la equiparación legislativa de los ciudadanos de la Unión Europea a los nacionales españoles a los efectos de su participación en elecciones municipales, evitándose así la reforma constitucional.

Respecto de este punto, señala el Tribunal que derechos como el de sufragio pasivo

"...sólo pueden ser conferidos a los extranjeros a través de la reforma de la Constitución. Pues bien, este límite constitucional desaparecería y con él la propia fuerza de obligar de la Constitución-si (...) pudiera el legislador acuñar o troquelar nacionalidades ad hoc con la única y exclusiva finalidad de eludir la vigencia de la limitación contenida en el artículo 13.2.. $\mathrm{CE}$ ".

El Tribunal se refiere, en este sentido, a las ficciones legales:

"...Siendo una de sus notas definitorias esenciales el no ser medio idóneo para operar sobre lo jurídicamente imposible, como lo es el reformar la Constitución al margen de los procedimientos expresamente previstos con tal objeto en los artículos 167 y 168 de la propia Constitución, procedimientos que el legislador, sometido como está al principio de supremacía de la Norma Fundamental, no puede en modo alguno soslayar, ni directamente, ni mediante la técnica indirecta, excepcional y subsidiaria de la fictio iuris".

Por todo ello, el Tribunal, al haber detectado que existe contradicción entre el precepto comunitario y el artículo 13.2 de la Constitución, señala que

89 El tema de las mutaciones constitucionales o modificaciones no formales de la Constitución ha sido estudiado, entre nosotros, por P. DE VEGA, La reforma constitucional y la problemática del poder constituyente, op. cit., en nota 88 , págs. 179 y ss. Las define este autor como uaquellos cambios operados en el mismo sin seguir el procedimiento más agravado y difícil establecido para la reforma de la Constitución". 
"...la única vía existente en Derecho para superar tal antinomia, y para ratificar o firmar aquel tratado es, así, la que ha previsto la Constitución en su artículo 95.1: la previa revisión de la norma fundamental en la parte de la misma que impone hoy la conclusión de esta declaración" (FJ 6).

Podemos, entonces, concluir señalando que, tras esta Declaración del Tribunal Constitucional, la Constitución ha visto reafirmada su supremacia y en general se ha visto reforzada la seguridad jurídica.

En efecto, habría supuesto una infravaloración de la Constitución y de su fuerza obligatoria la regulación del derecho de sufragio pasivo de los ciudadanos comunitarios sin proceder a esta reforma.

En este sentido, tras la Declaración de 1 de julio de 1992, puede afirmarse con M. JIMÉNEZ DE PARGA: «Por mucho que deseemos que el texto constitucional de 1978 se conserve inalterado con el fin de que arraigue entre los españoles el sentimiento constitucional, y aceptando la sabia recomendación de un famoso autor belga que dijo que "la Constitución hay que tocarla pocas veces y con mano temblorosa", yo creo que tampoco habría sido conveniente establecer una ordenación real en materia del voto de los ciudadanos de la Comunidad Europea, al margen de las reglas de la Norma Suprema. Retocar en este caso la Constitución era reconocer a la misma el valor superior que le corresponden ${ }^{90}$.

M. JiMÉnez de PARGA, "La «reformita»", La Crónica 16 de León, 2 de julio 


\section{BIBLIOGRAFÍA UTILIZADA}

Alegre Martinez, M. A., "Comunidades Autónomas y Derecho Comunitario Europeon, de inmediata aparición en el número 17, monográfico, de la Revista de la Facultad de Derecho de la Universidad Complutense de Madrid.

Almagro Nosete, J., y Saavedra Gallo, P., Justicia Constitucional (Comentarios a la Ley Orgánica del Tribunal Constitucional), Valencia, Tirant lo Blanch, 2. ${ }^{\mathrm{a}}$ ed., 1989.

Arnaldo AlcubiLla, E., "El derecho de sufragio de los extranjeros en las elecciones locales", Revista Española de Derecho Constitucional, n. 34, enero-abril 1992, págs. 67-97.

BAssols ComA, M., "La Constitución económica", ponencia presentada al Congreso La reforma constitucional en España, Logroño, 27-30 abril 1992. Próxima publicación.

Carrillo Salcedo, J. A., "La protección de los Derechos humanos en las Comunidades Europeas", en VV.AA. (dirigidos por E. GARCíA DE ENterRía, J. D. González Campos y S. Muñoz Machado), Tratado de Derecho comunitario, Madrid, Civitas, 1986, vol. III, págs. 17-26.

Corriente Córdoba, J. A., Derecho internacional público. Textos fundamentales, Madrid, Marcial Pons.

Cruz Villalón, P., "El control previo de constitucionalidad", Revista de Derecho Público, 2.. época, n.ำ 82, enero-marzo 1981, págs. 5-21.

Diez-Picazo, L. M., “¿Una Constitución sin declaración de derechos? (Reflexiones constitucionales sobre los derechos fundamentales en la Comunidad Europea)", Revista Española de Derecho Constitucional, ก. 32, mayo-agosto 1991, págs. 135-155.

García Arán, M., La prevaricación judicial, Madrid, Tecnos, 1990. 
Garcia de Enterría, E., La Constitución como norma y el Tribunal Constitucional, Madrid, Civitas, 3. ${ }^{\mathrm{e}}$ ed., 1985.

- "La participación de las Comunidades Autónomas en la formación de las decisiones comunitarias", Revista Española de Derecho Constitucional, año 11, n. 33, septiembre-diciembre 1991, págs. 3-27.

- y Fernández Rodriguez, T. R., Curso de Derecho Administrativo, vol. I, 5.9 edición, Madrid, Civitas, 1989.

Gimeno Sendra, V., Constitución y proceso, Madrid, Tecnos, 1988.

Gómez Montoro, A, J., «El control previo de constitucionalidad de proyectos de Estatutos de Autonomía y demás Leyes orgánicas", Revista Española de Derecho Constitucional, n.․2 22, enero-abril 1988, págs. 121-174.

GonzÁlez Pérez, J., Derecho procesal constitucional, Madrid, Civitas, 1980.

IsAAC, G., Manual de Derecho comunitario general, Barcelona, Ariel, 1. edición, 1985. Traducción de J. Bignozzi y J. Marfá.

Jiménez de Parga, M. "La "reformita" ", La Crónica 16 de León, 2 de julio de 1992.

Juste Ruiz, J., "La aplicación del Derecho comunitario europeo y la Constitución española de 1978", en VV.AA. (ed.: E. Álvarez Conde), Diez años de régimen constitucional, Madrid, Tecnos, 1989, págs. 273-298.

Lasagabaster Herrarte, l., "Las Comunidades Europeas y los derechos fundamentales", Revista Española de Derecho Constitucional, año 6, n.. 18, septiembre-diciembre 1986, págs. 51-82.

López Garrido, D., Código de la Comunidad Europea (2 volúmenes), Madrid, 1992.

LouIs, J. V., El ordenamiento jurídico comunitario, Luxemburgo, Oficina de Publicaciones Oficiales de las Comunidades Europeas, 2. edición, 1986.

Mangas Martin, A., Derecho comunitario europeo y Derecho español, 2.. edición, Madrid, Tecnos, 1987.

- "La reforma constitucional en España: los tratados internacionales (arts. 93 a 96 de la $(E)$ ", ponencia presentada al Congreso La reforma constitucional en España, Logroño, 27-30 abril 1992. Próxima publicación. 
Montoro Puerto, M., Jurisdicción constitucional y procesos constitucionales. Tomo II: Procesos de protección de los derechos fundamentales, Madrid, Colex, 1991.

Molina del Pozo, C. F., Manual de Derecho de la Comunidad Europea, Madrid, Trivium, 1987. (2a edición, 1990).

Muñoz MaCHADo, S., El Estado, el derecho interno y la Comunidad Europea, Madrid, Civitas, 1986.

Отто, lgnacio de, Derecho Constitucional. Sistema de fuentes, Barcelona, Ariel, 2." edición, 1988.

Péréz Tremps, P., «Justicia comunitaria, Justicia constitucional y Tribunales ordinarios frente al Derecho comunitario (Comentario a la Sentencia de la Corte Constitucional italiana número 170/1984, de 8 de junio)", Revista Española de Derecho Constitucional, año 5, n. 13, enero-abril 1985, págs. 157-181.

- Comunidades Autónomas, Estados y Comunidad Europea, Madrid, Ministerio de Justicia, 1987.

Remiro Brotons, A., "Controles preventivos y reparadores de la constitucionalidad intrínseca de los tratados internacionales", Revista de Derecho Político, n.ำ16, invierno 1982-1983, págs. 109-141.

- Derecho internacional público. Vol. II: Derecho de los tratados, Madrid, Tecnos, 1987.

Rodríguez-ZaPATA Y Pérez, J., "Derecho internacional y sistema de fuentes del Derecho: la Constitución española», en La Constitución española y las fuentes del Derecho, Madrid, Dirección General de lo Contencioso del Estado, Instituto de Estudios Fiscales, 1979, vol. III, págs. 1733-1770.

- "Los tratados internacionales y los controles de constitucionalidad", en VV.AA., El Tribunal Constitucional, Madrid, Dirección General de lo Contencioso del Estado, Instituto de Estudios Fiscales, 1981, págs. 2361-2410.

Ruiz Robledo, A., "El ordenamiento jurídico europeo y el sistema de fuentes español", Revista de Derecho Político, n.․ 32, 1991, págs. 29-54.

SÁnCHez Legido, A., "Las relaciones entre el Derecho comunitario y el Derecho interno en la jurisprudencia del Tribunal Constitucional", Revista Española de Derecho Constitucional, año 11, n. 33, septiembre-diciembre 1991, págs. 175-207. 
SÁnCHEZ Rodríguez, L. I., “El artículo 93 CE y el bloque de constitucionalidad: algunos problemas", en Estudios sobre la Constitución española. Homenaje al profesor Eduardo García de Enterría, Madrid, Civitas, 1991, tomo I, págs. 219-250.

Santaolalla López, Fernando, «Los Tratados como fuente del Derecho en la Constitución", en La Constitución española y las fuentes del Derecho, Madrid, Dirección General de lo Contencioso del Estado, Instituto de Estudios Fiscales, 1979, vol. III, págs. 1909-1938.

Torres del Moral, A., Principios de Derecho constitucional español, Madrid, Ediciones Átomo, 2.a edición, 1988; 3. a edición, Publicaciones de la Facultad de Derecho de la Universidad Complutense, 1992.

- Estado de Derecho y Democracia de Partidos, Madrid, Universidad Complutense (Servicio de Publicaciones de la Facultad de Derecho), 1991.

Torres Hernández, M. R., "La primacía del Derecho comunitario", Tapia, n.․ 49, diciembre 1989, págs. 19-22.

Vega GaRCiA, P., La reforma constitucional y la problemática del poder constituyente, Madrid, Tecnos («Temas Clave de la Constitución Española»), 1985.

VV.AA., Treinta años de Derecho comunitario, Luxemburgo, Oficina de Publicaciones Oficiales de las Comunidades Europeas, 1984

\section{Bibliografía complementaria}

AdAM MuÑoz, M. D., "El derecho de sufragio de los extranjeros residentes en España", Boletín Informativo Colex Data, n.ำ 1, abril 1992, págs. 11-20.

Alonso García, R., Derecho comunitario, Derechos nacionales y Derecho común europeo, Madrid, Civitas y Servicio de publicaciones Universidad Complutense, 1989.

- y BAÑo LEÓN, J. M., "El recurso de amparo frente a la negativa a plantear la cuestión prejudicial ante el Tribunal de Justicia de la Comunidad Europea", Revista Española de Derecho Constitucional, n.. 29, mayo-agosto 1990, págs. 193-222. 
Brugmans, H., L'idée européenne 1920-1970, Bruges, De Tempel, Templelhof, 1970.

Constantinesco, V., Compétences et pouvoirs dans les Communautés Européennes, París, Librairie Générale de Droit et de Jurisprudence, 1974.

Fernández Costales, «El Derecho civil español y el Derecho comunitario europeo" (I y II), Actualidad Civil, n. ${ }^{\text {os }} 3$ y 4, enero 1986.

Genevols, B., "Le Droit international et le Droit Communautaire", en VV.AA., Conseil Constitutionnel et Conseil d'État (Colloque des 21 et 22 janvier 1988, au Sénat), París, Librairie Générale de Droit et de Jurisprudence - Montchrestien, 1988, págs. 191-218.

GutiérRez EsPaDA, C., El sistema institucional de las Comunidades Europeas. De los Tratados constitutivos y el Acta Única al Proyecto de Tratado sobre la Unión Europea, Madrid, Tecnos, 1988.

Lasagabaster Herrarte, I., El ordenamiento jurídico comunitario, el estatal y el autonómico, Oñati, Instituto Vasco de Administración Pública, 1986.

López Castillo, A., "El exterior y la Comunidad Europea en el juego competencial interno", Revista Española de Derecho Constitucional, n.ㅇ 26, págs. 231-250.

LóPEZ GARRIDO, D., Libertades económicas y derechos fundamentales en el sistema comunitario europeo, Madrid, Tecnos, 1986.

Martínez VaL, José M.." "La "Declaración" del TC de 1 de julio de 1992 sobre la reforma del artículo 13.2 de la Constitución", Revista General de Derecho, n.․576, septiembre 1992, págs. 8149-8154.

Medina Ortega, M., La Comunidad Europea y sus principios constitucionales, Madrid, Tecnos, 1974.

Pérez Tremps, P., Constitución Española y Comunidad Europea, Madrid, Civitas - Fundación Universidad-Empresa, 1993.

Plender, R., y Pérez Santos, J., Introducción al Derecho Comunitario Europeo, Madrid, Civitas, 1985.

Remiro Brotons, A. "La constitucionalidad de los Tratados internacionales y su control por el Tribunal Constitucional", en VV.AA., El Tribunal Constitucional, Madrid, Dirección General de lo Contencioso del Estado, Instituto de Estudios Fiscales, 1981, vol III, págs. 2229-2267. 
Requejo Pages, J. L., "Consideraciones en torno a la posición de las normas internacionales en el ordenamiento español", Revista Española de Derecho Constitucional, n. 34, enero-abril 1992, págs. 41-66.

Rubio Llorente, F., "La Constitución Española y el Tratado de Maastricht», Revista Española de Derecho Constitucional, n.ำ 36, 1992, págs. 253265.

Soriano, J. E., "Comunidades Autónomas, Comunidades Europeas y Tribunal Constitucional", Revista de Derecho Político, n.ำ 29, 1989, págs. 9-36.

VV.AA., Estudios de Derecho Comunitario Europeo, Consejo General del Poder Judicial, 1989.

- (Coord.: L. Aguiar de LuQUe), Implicaciones constitucionales y políticas del ingreso de España en la CEE y su incidencia en las Comunidades Autónomas, Actas del $V$ Congreso de la Asociación Española de Ciencia Política y Derecho Constitucional, Bilbao y San Sebastián, 9-11 octubre 1985.

- La crisis del Estado y Europa (Actas del Congreso celebrado en el seno del II Congreso Mundial Vasco, en Vitoria-Gasteiz, 19-23 octubre 1987), Oñati, Instituto Vasco de Administración Pública, 1988.

- (Coord.: V. Abellán), La integración de España en las Comunidades Europeas y las competencias de las Comunidades Autónomas (Coloquio organizado por la Asociación Española para el Estudio del Derecho Europeo, Barcelona, 1983), Barcelona, Generalitat de Catalunya, 1985.

- (Dirigidos por E. Garcia de Enterria, J. D. González Campos y S. Muñoz MACHADO), Tratado de Derecho comunitario (3 volúmenes), Madrid, Civitas, 1986. 